\title{
Human Poisoning
}

from Native and

\section{Cultivated \\ Plants}

James W. Hardin

Jay M. Arena, M.D.
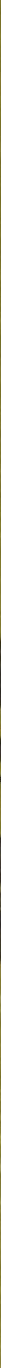
Almost every person has at one time or another suffered from the allergies, skin rashes, and wounds caused by certain kinds of plants. Other people learn even harder lessons: more than 15,000 Americans each year are internally poisoned by plants, and well over 100 of them die. And the dangerous and bothersome poisonous plants that cause all of this trouble surround us every day of our lives. Seldom is a poisonous plant out of reach. They grow wild and are carefully cultivated as ornamentals; we plant them in our gardens and pick them in fields and forests.

But, as the authors say in their Introduction, this book certainly does not "recommend the elimination or eradication of native and exotic plants which are dangerous," nor does it "want to make people afraid to venture out-of-doors." All dangers cannot be removed from our environment, but we can learn to recognize and avoid them.

Of course, under normal conditions an adult would not think of touching or eating a plant he knew to be poisonous; a word to the wise is sufficient. But the situation is much more dangerous when children are involved. Youngsters are curious; they will eat or chew anything merely for the sake of novelty or because some other child has dared them to. Unfortunately, only a small amount of the toxin from "forbidden fruits" can have severe or fatal consequences.

Written by a botanist and a pediatrician who have both had years of experience with poisonous plants in the field, laboratory, and clinic, this book deals not only with internal poisoning caused by eating plant parts, but also with the effects and treatment of plant allergies and dermatitis. How to avoid being poisoned by plants is the first consideration, although first-aid measures are described for those cases in which the warnings come too 



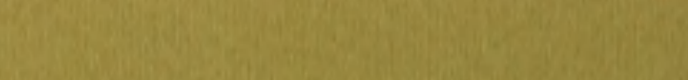

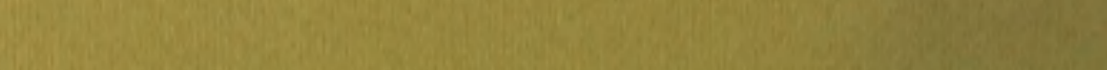
(4)

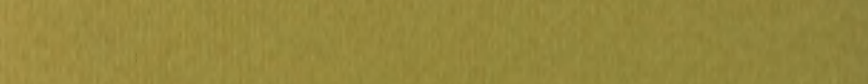

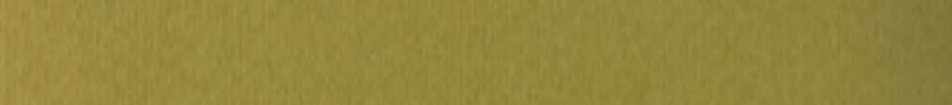

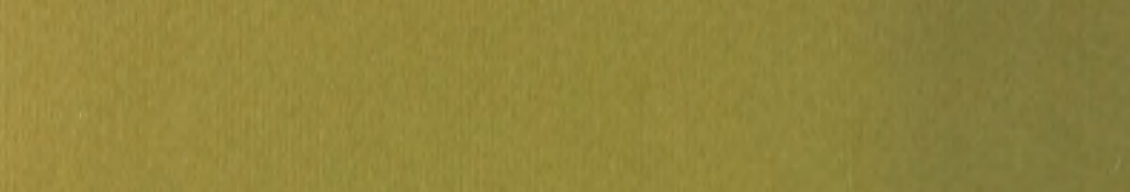

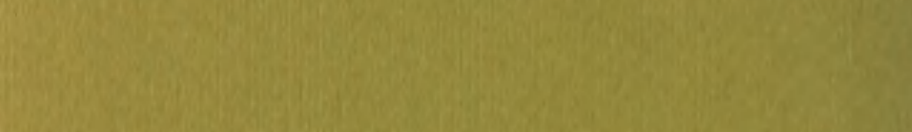

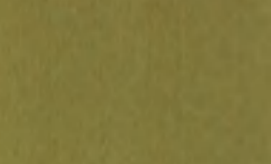

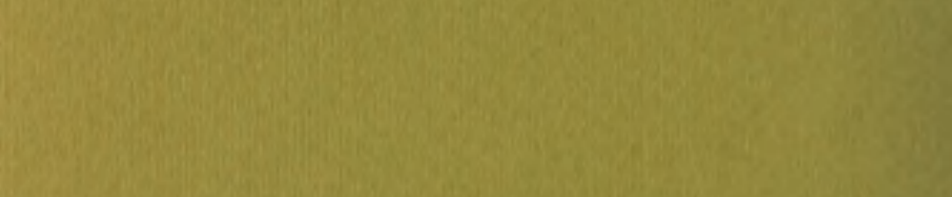

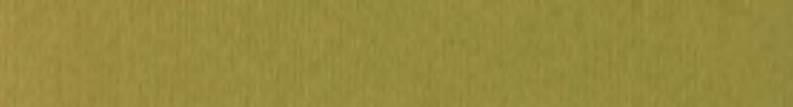

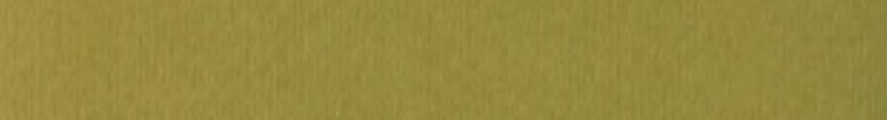
(20.9. (6)

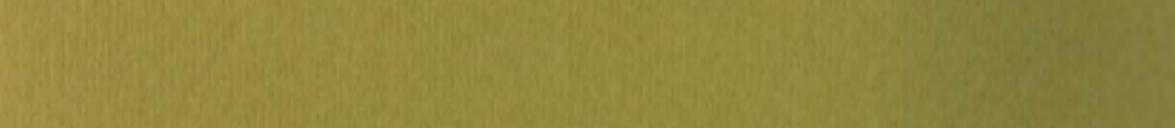

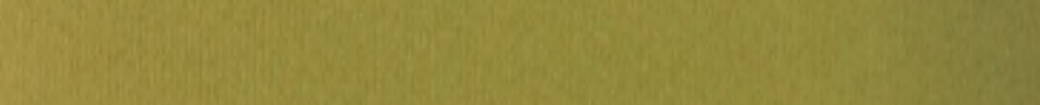
Q6.

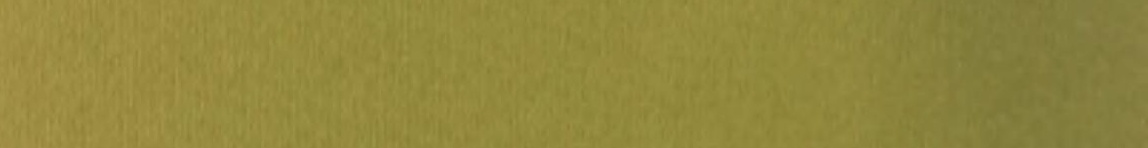

(2)

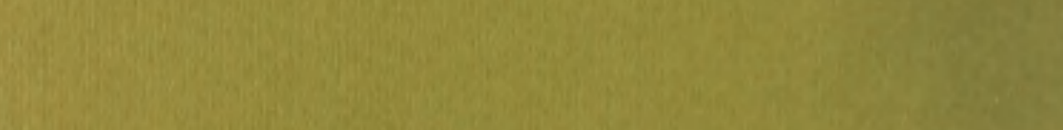
A. Hof

SW

Hown

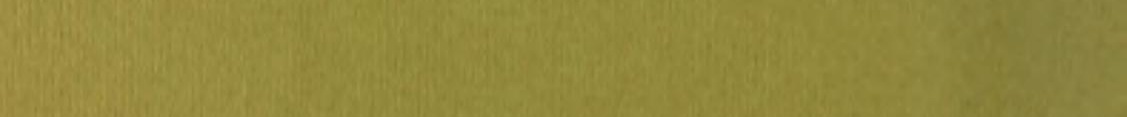

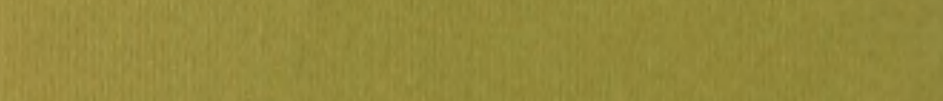
(6)

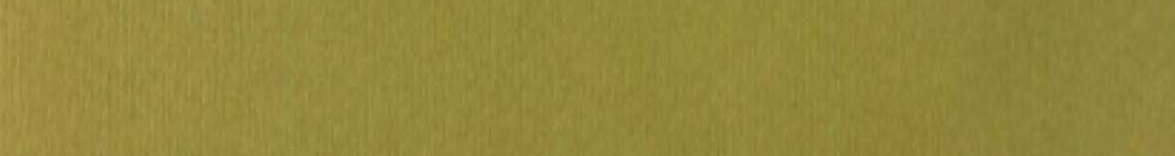

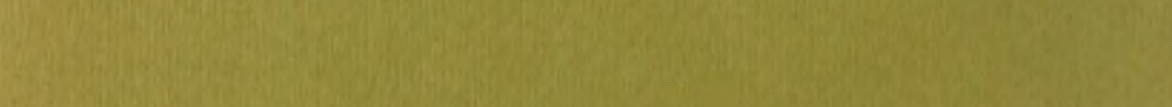

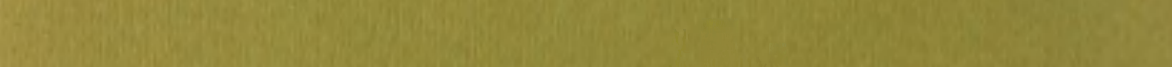

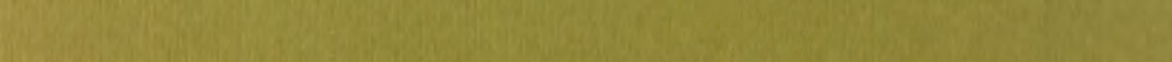

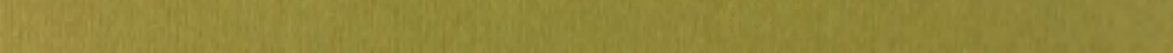
Dhy 
Human poisoning from native and cultivated plants 
Digitized by the Internet Archive in 2020 with funding from Duke University Libraries 


\title{
HUMAN POISONING FROM NATIVE AND CULTIVATED PLANTS
}

\author{
James W. Hardin \\ Jay M. Arena, M.D.
}

Duke University Press

Durham, North Carolina 
(1) 1969 by Duke University Press

Library of Congress Catalogue Card Number 73-83719 SBN 8223-0209-8

Printed in the United States of America by Litho Industries, Inc., Raleigh, N. C. 


\section{PREFACE}

Most of the existing literature on poisonous plants deals with those that are poisonous to livestock. We have felt a real need for a source of information on just those plants poisonous to humans - particularly children. Physicians, health officers, nurses, scout leaders, camp counselors, teachers, parents, and many others should not only know the dangerous plants of their area but have a ready reference in case of emergencies. This book has been written with these people in mind and has grown out of a number of years' experience with poisonous plants accumulated by both of us in the field, laboratory, and clinic.

We are indebted to our colleagues and to the numerous people who have brought cases of human poisoning to our attention and have in various ways contributed to the information presented here. Our information has been combined with details from the literature on poisonous plants, the most complete summary of which is by Dr. John M. Kingsbury of Cornell University, Poisonous Plants of the United States and Canada (Prentice-Hall, 1964).

The photographs, unless otherwise credited, were taken by Hardin under a project supported by the North Carolina Agricultural Experiment Station, and many were originally published in that station's Bulletin 414. The support of the research and permission to reproduce the figures are both gratefully acknowledged.

Figures 6-9 were very kindly supplied by Dr. L. R. Hesler, Emeritus Professor of Botany, University of Tennessee; Figures 8 and 9 are from his book Mushrooms of the Great Smokies, published by the University of Tennessee Press 
(1960) and used here with permission. Figure 18 is from the Missouri Agricultural Experiment Station Bulletin 433 and is used here with permission. Figure 19 was generously supplied by the North Carolina State Bureau of Investigation, and we appreciate the aid of Mr. William S. Best, chemist for the North Carolina SBI, in supplying information on narcotics. Figures or parts of figures 3, 26, 29, 30, 35, 42, 44,46 , and 49 are USDA photographs. The drawings for Figures 5, 15, 24, 47, and 48 are from Flora of West Virginia (W. Va. Univ. Bull., 1953, 1958) and are used with the permission of Dr. Earl L. Core. Figures 10, 27, 31, 34, 39, 41, and 45 are from Florida Agricultural Experiment Station Bulletin 510 and Circular S-100. The line drawings, Figures 51-55, are by Hardin, and all but Figure 51 were originally published in his Workbook for Woody Plants (Burgess Publishing Company, 1960). We are indeed grateful for all of these illustrations.

JAMES W. HARDIN

JAY M. ARENA 


\section{CONTENTS}

INTRODUCTION 3

Thirteen ways to avoid plant poisoning 5

List of dangerous plants 6

ALLERGIES 9

DERMATITIS 12

Most common causes of dermatitis 15

Phytophotodermatitis: Solar dermatitis

from plants 22

INTERNAL POISONING 25

First aid: What to do in case of internal poisoning 26

Common Poisonous plants 27

Poisonous and non-poisonous berries 126

POISONING OF PETS 135

GLOSSARY 137

BIBLIOGRAPHY 148

INDEX TO SCIENTIFIC AND COMMON NAMES 154 


\section{ILLUSTRATIONS}

1. Common ragweed (Ambrosia artemisifolia)

2. Trumpet creeper or cowitch (Campsis radicans) 15,16

3. Poison ivy (Toxicodendron radicans) 19,20

4. Poison sumac (Toxicodendron vernix) 21

5. Stinging nettle (Urtica dioica) 23

6. Destroying angel (Amanita verna) 30

7. Browning amanita (Amanita brunnescens)

8. Jack $-0^{\prime}$-lantern mushroom (Clitocybe illudens)

9. Morgan's lepiota (Lepiota molybdites) 33

10. Glory lily (Gloriosa superba) 37

11. Dumbcane (Dieffenbachia sp.) 40

12. Jack-in-the-pulpit (Arisaema triphyllum)

13. Moonseed (Menispermum canadense)

14. Baneberry (Actaea pachypoda) 45

15. Mayapple (Podophyllum peltatum)

16. Bleeding heart (Dicentra eximia)

17. Pokeweed (Phytolacca americana)

18. Corn cockle (Agrostemma githago)

19. Peyote (Lophophora williamsii)

20. Black cherry (Prunus serotina)

21. Jequirity pea or rosary pea (Abrus precatorius)

22. Black locust (Robinia pseudoacacia)

23. Wisteria (Wisteria sinensis) 69

24. Marijuana (Cannabis sativa) 71

25. Virginia creeper (Parthenocissus quinquefolia) 76

26. Mistletoe (Phoradendron serotinum) 77 
27. Chinaberry (Melia azedarach) 78

28. Painted buckeye (Aesculus sylvatica) 80,81

29. Water hemlock (Cicuta maculata) 84, 85

30. Poison hemlock (Conium maculatum) 86, 87

31. Tung nut (Aleurites fordii) 89

32. Crown-of-thorns (Euphorbia milii) 91

33. Milk bush or pencil tree (Euphorbia tirucallii) 93

34. Purge nut or Barbados nut (Jatropha curcas) 95

35. Castor bean (Ricinus communis) 96, 97

36. Mountain laurel (Kalmia latifolia) 99

37. Rhododendron (Rhododendron maximum) 101

38. Yellow jessamine (Gelsemium sempervirens) 103

39. Yellow allamanda (Allamanda cathartica) 104

40. Dogbane (Apocynum cannabinum) 105

41. Crape jasmine (Ervatamia coronaria) 106

42. Oleander (Nerium oleander) 107

43. Elderberry (Sambucus canadensis) 110

44. Jimsonweed (Datura stramonium) 112

45. Angel's trumpet (Datura suaveolens) 115

46. Black nightshade (Solanum americanum) 118

47. Horse nettle (Solanum carolinense) 119

48. Deadly nightshade (Solanum dulcamara) 119

49. Lantana (Lantana camara) 123

50. White snakeroot (Eupatorium rugosum) 125

51. Parts of a mushroom 140

52. Twigs and leaves 141

53. Leaf forms 142

54. Leaf shapes $143,144,145$

55. Flower parts and inflorescences 146, 147 

Human poisoning from native and cultivated plants 



\section{INTRODLCTION}

Plants can be dangerous!

Our pioneer forefathers and the agrarian society in general before and through the early nineteenth century had a serious problem with the numerous poisonous plants, few of which were known to them as poisonous. Many of the poisonings reaching near epidemic proportions in those times - such as the "milk sickness" in the Appalachians and Midwest caused by white snakeroot-have been virtually eliminated today by modern food processing and by the fact that a smaller percentage of our population lives in such direct contact with natural vegetation. One might assume from this that plant poisoning to man is no longer a problem. This is not the case, for many areas of North America are still largely rural. Even though there is a constant migration to the cities, there is also a distinct countermigration from the cities into a suburban environment with space for large lawns, gardens, and patios. Suburban plantings are using more and more cultivated exotics from around the world. Increasing numbers of families are camping and hiking in fields and forests and in general are spending more recreation time out-of-doors with plants unfamiliar to them. All these conditions mean that poisonous plants still can be, and still are, the cause of serious illnesses or even death among children and adults. In recent years approximately 3.5 per cent of all poisonings has been due to plants.

In our modern civilization, and particularly in view of our eagerness to return to nature, we should remember that we are seldom out of easy reach of some poisonous plantwhether it be in field or forest, swamp or bog, flower garden 
or vegetable garden, around the home or in it (see the lists of dangerous plants, pp. 6-8). Poisonous plants are to be found among all types of native plants: algae, fungi, ferns, herbs, vines, shrubs, and trees. Some of our most prized cultivated ornamentals are extremely dangerous (though one should not overlook the fact that symptoms may be caused by sprays applied to ornamentals rather than by the plants themselves).

The term "poisonous plant" designates many kinds of plants as well as a wide range of poisonous or disturbing effects. These effects may generally be classified as: (1) allergies, or allergic reactions to wind-blown spores or pollen; ( 2 ) dermatitis, or skin irritation caused by direct or indirect contact with a plant; ( 3 ) internal poisoning caused by eating plant parts; and ( 4 ) mechanical injury from sharp prickles, spines, or thorns found on many plants. The first three categories are the chief concern of this book and will be discussed further; the fourth category may not be considered "poisoning" in the true sense, but mechanical injury may lead to secondary infections requiring medical attention.

Under normal circumstances no adult would think of touching or eating poisonous plants, yet they are contacted and even eaten accidentally or swallowed thoughtlessly. Many poisonous plants have such an unpleasant taste that it is not likely that any adult would chew on them very long or swallow them. But some poisonous plants are not at all distasteful and may be eaten in enough quantity to cause serious disturbances or even death. Fortunately, relatively large amounts of most plants are necessary to produce serious or fatal poisoning in man.

The situation with regard to children is much more dangerous. Small children have a great curiosity and will often chew on anything within reach. Much smaller amounts of the toxin are needed to cause very severe or fatal results. One or two seeds could cause death. Even youngsters will sample almost anything, especially in play or when there is a dare involved.

The objectives of this book are to increase the awareness of these potential dangers, to aid in the identification of the 
more common poisonous plants native to or cultivated in the United States (including Alaska and Hawaii) and Canada, and to assist physicians in the recognition of symptoms and treatment of such cases.

We do not wish to recommend the elimination or eradication of native and exotic plants which are dangerous, and by no means do we want to make people afraid to venture outof-doors. All dangers cannot be removed from our surroundings, but we can learn to recognize and avoid them. We do wish, however, to call attention to poisonous plants as potential hazards that surround us so that appropriate precautions can be taken.

We hope that an awareness of these potential dangers, with appropriate education of children, can measurably decrease the number of cases of plant poisoning that occur each year. Plants known to be dangerous should be given the same respect as other, more publicized, household hazards. There is little excuse for the fact that most plant poisonings occur in the home or yard.

\section{Thirteen ways to avoid plant poisoning}

1. Become familiar with the dangerous plants in your area, yard, and home. Know them by name.

2. Do not eat wild plants, including mushrooms, unless positive of identification.

3. Keep plants, seeds, fruits, and bulbs away from infants.

4. Teach children at an early age to keep unknown plants and plant parts out of their mouths. Make them aware of the potential danger of poisonous plants.

5. Teach children to recognize poison ivy or other causes of dermatitis in your area.

6. Be certain you know the plants used by children as playthings (seeds or fruits, stems, etc.) or as skewers for meat or marshmallows.

7. Do not allow children to suck nectar from flowers or make "tea" from leaves.

8. Know the plant before eating its fruits.

9. Do not rely on pets, birds, or squirrels to indicate nonpoisonous plants. 
10. Avoid smoke from burning plants, unless you know exactly what they are.

11. Remember, heating and cooking do not always destroy the toxic substance.

12. Store labeled bulbs and seeds safely away from children and pets.

13. Do not make homemade medicines from native or cultivated plants.

\section{List of dangerous plants}

Native or naturalized plants of woods, fields, bogs, lawns, and disturbed areas

Dermatitis

Manchineel
Poison ivy
Poison oak
Poison sumac

Internal poisons

Apple-of-Peru
Baneberry
Beech
Black cherry
Black locust
Black snakeroot
Bloodroot
Blue cohosh
Buckeye
Buckthorn
Burning bush
Buttercup
Chinaberry
Coontie
Corn cockle
Coyotillo
Cycads
Dicentra
Dogbane

Poisonwood

Spotted spurge

Spurge nettle

Stinging nettle

Elderberry

Elephant ear

False hellebore

Golden seal

Ground cherry

Holly

Horse nettle

Hydrangea

J ack-in-the-pulpit

Jequirity pea

Jimsonweed

Kentucky coffee tree

Larkspur

Lobelia

Mayapple

Mescal bean

Mexican pricklepoppy
Trumpet creeper

Wild parsnip

Woodnettle

Mistletoe

Monkshood

Moonseed

Mountain laurel

Mulberry

Mushrooms

Nightshade

Oak (acorns)

Poison hemlock

Pokeweed

Prickly poppy

Rattlebox

Rayless goldenrod

Rhododendron

Rock poppy

Spurge

Star-of-Bethlehem

Strawberry bush

Virginia creeper 
Water hemlock Wild balsam apple Yellow nightshade

White snakeroot Yellow jessamine Yew

Cultivated plants of the yard and garden

\section{Dermatitis}

Gas plant

Internal poisons

\begin{tabular}{|c|c|c|}
\hline Akee & Daphne & Narcissus \\
\hline Amaryllis & Devil's trumpet & Ochrosia plum \\
\hline Anemone & Dieffenbachia & Oleander \\
\hline Angel's trumpet & Duranta & Pencil tree \\
\hline Arnica & English ivy & Physic nut \\
\hline Autumn crocus & Fava bean & Poinciana \\
\hline Azalea & Finger cherry & Pongam \\
\hline Belladonna & Four-o’clock & Prickly poppy \\
\hline Betel nut & Foxglove & Privet \\
\hline Bird-of-paradise & Glory lily & Purge nut \\
\hline Bittersweet & Golden chain & Rattlebox \\
\hline Black henbane & Hill gooseberry & Rhododendron \\
\hline Bleeding heart & Holly & Rhubarb \\
\hline Boxwood & Horsechestnut & Rubber vine \\
\hline Burning bush & Hyacinth & Sandbox tree \\
\hline Caladium & Hyacinth bean & Snow-on-the- \\
\hline Caper spurge & Hydrangea & mountain \\
\hline Cassava & Jessamine & Spring adonis \\
\hline Castor bean & Jerusalem cherry & Spurge \\
\hline Cestrum & Jetbead & Star-of-Bethlehem \\
\hline Cherry & Kentucky coffee & Sweet pea \\
\hline Chinaberry & tree & Tobacco \\
\hline Christmas rose & Larkspur & Tomato \\
\hline Clematis & Lantana & Trumpet flower \\
\hline Coca & Laurel & Tung oil tree \\
\hline Crape jasmine & Lignum vitae & Wisteria \\
\hline Crownflower & Lily-of-the-valley & Yellow allamanda \\
\hline Crown-of-thorns & Mescal bean & Yellow jessamine \\
\hline Cycads & Monkshood & Yellow oleander \\
\hline Cypress spurge & Mustard & Yew \\
\hline
\end{tabular}


House plants

$\begin{array}{lll}\text { Amaryllis } & \text { Dieffenbachia } & \text { Narcissus } \\ \text { Bird-of-paradise } & \text { Glory lily } & \text { Pencil tree } \\ \text { Crown-of-thorns } & \text { Hyacinth } & \text { Philodendron } \\ & & \text { Poinsettia }\end{array}$

Christmas greenery

$\begin{array}{lll}\text { Boxwood } & \text { Holly } & \text { Mountain laurel } \\ \text { English ivy } & \text { Jequirity pea } & \text { Poinsettia } \\ \begin{array}{c}\text { European } \\ \text { bittersweet }\end{array} & \text { Jerusalem cherry } & \text { Yew } \\ & \text { Mistletoe } & \end{array}$

Narcotics-Hallucinogenic drugs

Betel nut

Coca

Marijuana

$\begin{array}{ll}\text { Morning glory } & \text { Nutmeg } \\ \text { seeds (heavenly } & \text { Opium poppy } \\ \text { blue, pearly } & \text { Peyote } \\ \text { gates) } & \end{array}$




\section{ALLERGIES}

Allergy is a condition of unusual sensitivity which certain individuals may have or develop to substances ordinarily harmless. These sensitizing substances are called allergens. Spores from numerous fungi, some soil algae, and pollen grains from seed plants cause allergic reactions in susceptible individuals. These wind-blown plant structures (aeroallergens) are "poisonous" in the broad sense. There are estimated to be thirteen million sufferers from plant aeroallergens each year.

Fungi are all around us. The spores are microscopic in size and are easily carried in the atmosphere. The humid areas of North America have a fairly high and constant count of atmospheric fungus spores. Certain microscopic soil algae are also wind-blown and cause allergic reactions.

Pollen counts are more seasonal depending upon the flowering period for certain plant species. There are generally three seasonal peaks in the frequency of pollen in the atmosphere. The first is in the early spring, caused by the early flowering of such trees as oak, elm, cedar (juniper), maple, sycamore, ash, alder, birch, poplar, hickory, beech, and others throughout the country. The counts are highest in the deciduous forest area of the eastern United States and amount to a few hundred pollen grains per cubic yard of atmosphere. The problem of treatment is complicated by the great number of different kinds of trees involved.

The second peak in pollen frequency comes in midsummer and is caused primarily by grasses of various types, some herbs, and a few late-flowering trees. The counts at this time may also be a few hundred grains per cubic yard of atmos- 
phere and are fairly equally distributed throughout the country.

The third and highest peak comes in the fall with the flowering of ragweeds and a few other herbs. Ragweeds (Figure 1) are found throughout the country, and the pollen is by far the most abundant and most toxic of all aero-

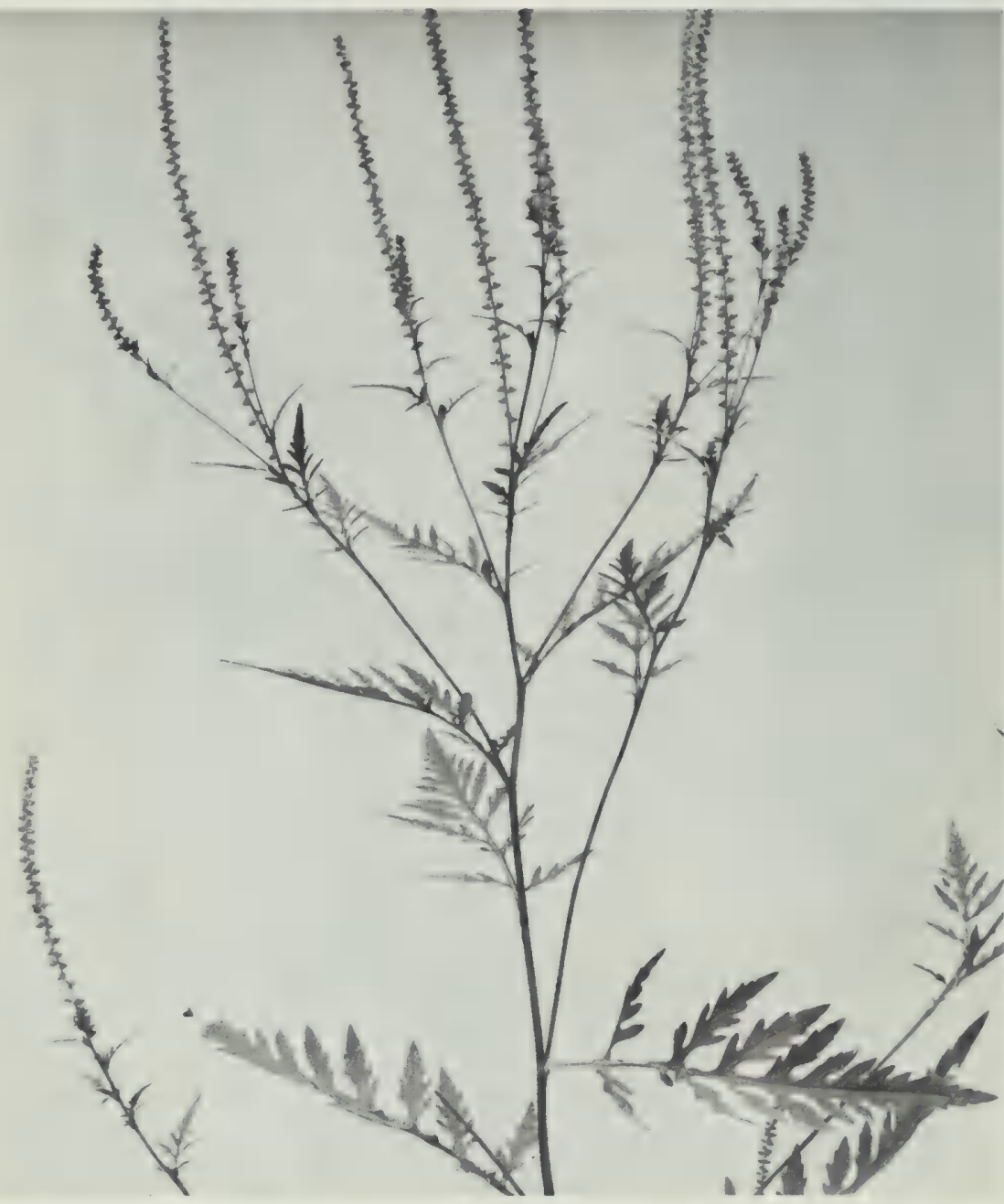

Figure 1. Common ragweed (Ambrosia artemisiifolia) A ubiquitous weed with terminal spikes of numerous pollen flowers. 
allergens. Ragweed counts range from a few hundred to nearly two thousand grains per cubic yard of atmosphere. Most of the eastern United States has a high count, but in the plains area between the Rockies and the Appalachians the great abundance of ragweed pollen is astonishing. This "breadbasket of America" is a veritable pollen basket as well, for almost every wheat field is also a ragweed field.

There are a few real refuges from ragweed pollen. Very low counts are found in northern Wisconsin, the upper peninsula of Michigan, the mountains of upper New York, Maine, and New Hampshire, central and eastern Canada, southern Florida and the Caribbean, and west of the Rocky Mountains. Alaska and Hawaii have hardly any ragweed pollen.

Hay fever, untreated, may lead to asthma and other serious complications. The asthmatic child, if his particular sensitivity is not detected and if proper care is not given, may be retarded physically and may have permanent involvement of the heart, lungs, and chest wall with invalidism. If allergy is at all suspected, see your physician or allergist as soon as possible. 


\section{DERMATITIS}

There are numerous plants which may cause dermatitis, an irritation to the skin. Any one individual may be susceptible to many of these plants, to only a few, or to none at all. Dermatitis, like allergy, is dependent upon a previous sensitivity of the individual.

The degree of poisoning may vary from minor or temporary skin irritation to very painful inflammation with blisters persisting for weeks and possibly requiring hospitalization. The severity depends on the plant contacted, the degree of contact, and the relative susceptibility of the individual. Those plants considered to be the most troublesome are listed below preceded by an asterisk $(*)$ and are described following this tabulation of all those suspected of causing dermatitis. (The abbreviation spp. means any of the various species rather than a particular one.)

Scientific name

Agave spp.

Ailanthus altissima

Allamanda cathartica

Ambrosia artemisiifolia

Anacardium occidentale

Anagallis arvensis

Anthemis cotula

Aralia spinosa

Arisaema triphyllum
Common name

Century plant

Tree-of-heaven

Yellow allamanda

Ragweed

Cashew nut

Scarlet pimpernel

Dog fennel

Hercules' club

Jack-in-the-pulpit
Plant part sap leaves,

flowers

all parts

leaves

nut

shell, oil

leaves

leaves,

flowers

bark

leaves,

roots 
Asarum canadense

Asimina triloba

Asparagus officinalis

Buxus sempervirens

* Campsis radicans

Capsicum frutescens

Carica papaya

Caryota mitis

Catalpa spp.

Caulophyllum thalictroides

Chelidonium majus

Chimaphila umbellata

Chrysanthemum spp.

Citrus aurantifolia

Clematis virginiana

Cnidoscolus spp.

Conium maculatum

Cryptostegia

madagascariensis

Cypripedium spp.

Datura stramonium

Daucus carota

Delphinium ajacis

Dicentra spp.

Dirca palustris

Erigeron canadensis

* Euphorbia spp.

Ficus spp.
Wild ginger

Pawpaw

Asparagus

Boxwood

Trumpet creeper, leaves, cowitch

Bird pepper

flowers

Papaya

fruit

Tufted fishtail palm fruit

Catalpa

Blue cohosh

Celandine

Prince's pine, pipsissewa

Chrysanthemum, daisy

Lime

Virgin's bower

Spurge nettle, stinging spurge

Poison hemlock

flowers

roots

juice

leaves, stems

leaves

thorn, peels

leaves

stinging

hairs

leaves

Rubber vine

all parts

Lady's slipper orchid leaves

Jimsonweed

leaves,

flowers

Wild carrot

leaves

Larkspur

leaves, seeds

Bleeding heart

all parts

Leatherwood

bark

Daisy fleabane,

leaves horseweed

Spurge, poinsettia, milky pencil tree

Fig

juice 


\section{Gelsemium sempervirens}

Ginkgo biloba

Grevillea banksii

Hedera helix

* Hesperocnide spp.

* Hippomane mancinella

Hypericum perforatum

Iris spp.

Juniperus virginiana

* Laportea canadensis

Leonurus cardiaca

Lobelia inflata

Maclura pomifera

Mangifera indica

Melaleuca leucadenra

* Metopium toxiferum

Morus rubra

Nerium oleander

Phacelia spp.

Pithecellobium dulce

Plumbago capensis

Plumeria spp.

Podophyllum peltatum

Polygonum spp.

Polyscias spp.

Primula spp.

Ranunculus spp.

Rhaphidophora aurea
Yellow jessamine

leaves,

stems

Ginkgo, maidenhair seeds tree

Kahili flower

all parts

English ivy

leaves

Western stinging

stinging nettle

hairs

Manchineel

milky

juice

St. John's wort

leaves

Iris, flag

rhizomes

Juniper, red cedar

leaves

Wood nettle

stinging

hairs

Motherwort leaves

Lobelia, Indian

tobacco

leaves

Osage orange, horse milky apple

juice

Mango

sap,

fruit

peel

Punk tree, cajeput sap

Poisonwood

Red mulberry

all parts

leaves,

stem

Oleander leaves

Phacelia leaves

Pithecellobium sap

Plumbago

all parts

Frangipani

sap

Mayapple, mandrake roots

Smartweed,

leaves

knotweed

Polyscias

all parts

Primrose

leaves

Buttercup

leaves

Hunter's robe 
Rhoeo spathacea

Rumex spp.

Sanguinaria canadensis

Schinus terebinthifolius

Senecio confusus

Setcreasea purpurea

* Toxicodendron spp.

Trifolium hybridum

Urica dioica

Veratrum spp.
Oyster plant

Dock, sorrel

Bloodroot

Brazilian pepper

Mexican flame vine

Purple queen

Poison oak, ivy and all parts sumac

Alsike clover

Stinging nettle

Hellebore sap

leaves

sap

flowers,

fruits

all parts

sap

leaves

stinging

hairs

leaves

\section{Most common causes of dermatitis}

\section{Campsis radicans (L.) Seeman-Trumpet creeper, cowitch (Figure 2)}

Description: Woody vine, climbing along fences or high in shrubs, trees, and poles; leaves opposite, pinnately divided into 9-11 ovate leaflets with toothed margins; flowers in

Figure 2. Trumpet creeper or cowitch (Campsis radicans) A common vine of eastern United States with divided leaves, yellow to red tubular flowers, and pod. like fruits with many winged seeds. (See next page.)

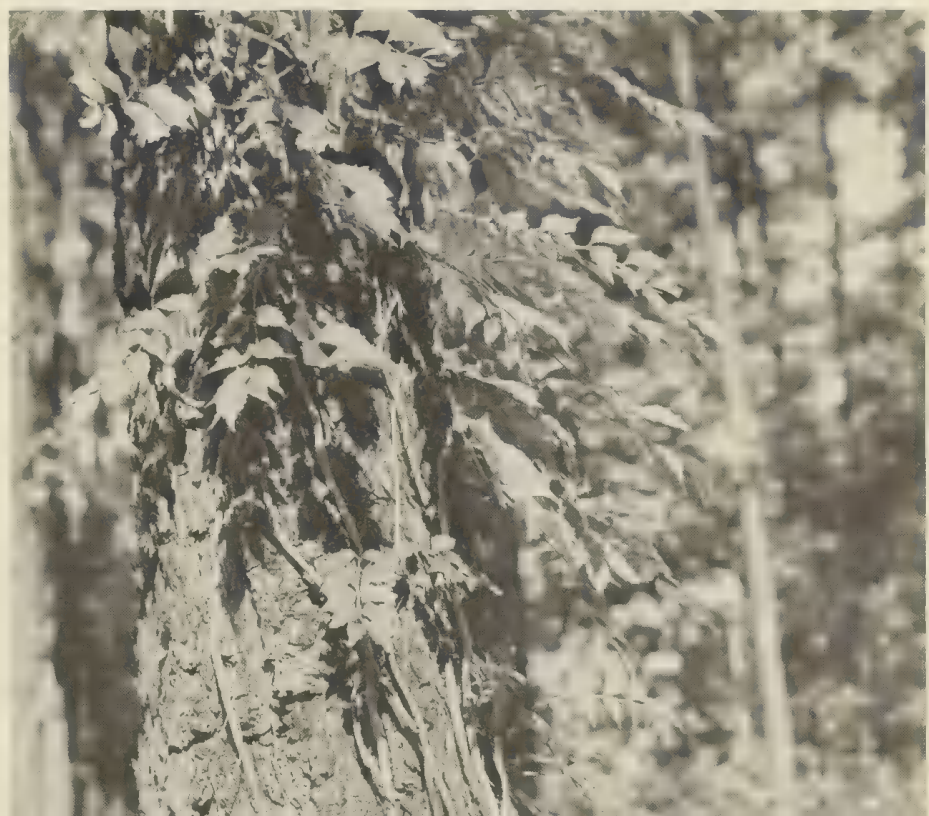


Euphorbia maculata L.-Spotted spurge, eyebane, milk purslane, wartweed

Description: Herbaceous perennial with milky juice; stem erect or prostrate; leaves opposite, dark green, and usually with a dark reddish spot near the middle, hairy, oblong, to $3 / 4$ in. long, margin with very small teeth; "flowers" small and inconspicuous with minute white bracts.

Occurrence: Eyebane is a native herb throughout eastern and midwestern United States and is an occasional weed in the Pacific states. It grows as a weed in lawns, gardens, waste places, roadsides, and fields. Other species of Euphorbia, including poinsettia, found in all parts of the country or cultivated, may be equally poisonous to some people.

Poisoning: Inflammation developing after contact and forming large blisters lasting several days. Small children seem most susceptible.

\section{Hippomane mancinella L.-Manchineel}

Description: Tree to $50 \mathrm{ft}$. tall with milky juice; leaves alternate, simple, long-stalked, the blades broadly ovate to elliptical, 2-6 in. long, margin finely toothed; flowers small, greenish, in stiff spikes; fruit a drupe about $11 / 2$ in. across.

Occurrence: Manchineel is a native tree found originally in hammocks near the coast at the southern tip of Florida and on the Keys. It is now rare except in the Everglades National Park.

Poisoning: Severe skin reaction and temporary blindness if eyes are rubbed with infected fingers. This has the reputation of being one of the worst causes of dermatitis in the country. The milky juice was once used by Indians as a poison for arrow tips and also as an ingredient for native medicines.

Laportea canadensis (L.) Wedd.-Wood nettle, nettle

Description: Erect perennial herb to $5 \mathrm{ft}$. tall and with conspicuous stinging hairs throughout; leaves alternate, stalked, broadly ovate to 6 in. long, pointed at apex, coarsely toothed; flowers small and inconspicuous, in slender branches from the leaf axils. 
Occurrence: Wood nettle is native in various areas throughout castern United States. It is usually found in moist woods and along streams or rivers, roadsides, and ditches, often forming dense local populations.

Poisoning: Intense burning and itching or stinging of the skin persisting for various lengths of time. The stinging hairs have a mechanism similar to a hypodermic. There is a very fine capillary tube, a bladder-like base filled with the chemical irritant, and a minute spherical tip which easily breaks off on contact, leaving a very sharp-pointed tip which easily penetrates the skin. The chemical is forced into the skin through the tube as the hair bends and constricts the bladder-like base. The irritating chemicals are histamine, acetylcholine, and 5-hydroxytryptamine $(5-\mathrm{HT})$, rather than formic acid as once thought. The stinging hairs of Cnidoscolus, Hesperocnide, and Urtica are of similar structure.

\section{Metopium toxiferum (L.) Krug \& Urban-Poisonwood, coral sumac}

Description: Shrub or tree to $35 \mathrm{ft}$. tall; leaves alternate, pinnately divided with 3-7 (usually 5) leaflets, each leathery and to $3 \frac{1}{2}$ in. long; flowers yellow-green, in panicles; fruit oval, to $1 / 2$ in. across, orange-yellow.

Occurrence: Poisonwood is a native tree of hammocks, pinelands, and along the coast at the southern tip of Florida and on the Keys.

Poisoning: The sap causes very severe skin irritation similar to poison ivy, appearing a few hours to 5 days after contact. Fever and other internal complications can result in very severe cases.

Toxicodendron diversilobum ( T. \& G.) Green (Rhus diversiloha T. \& G.)-Western poison oak

This species is similar to poison ivy and is found commonly from British Columbia southward into Mexico. It grows in low places, thickets, and wooded slopes usually below 5,000 $\mathrm{ft}$. elevation.

Poisoning: See T. vernix. 
Toxicodendron quercifolium (Michx.) Greene (Rhus toxicodendron L.)-Poison oak

Description: Shrub, never climbing; leaves alternate, with 3 leaflets, each densely hairy below, deeply toothed or lobed, and coarse-looking; flowers and fruits in hanging clusters, the fruit a yellowish and hairy drupe.

Occurrence: A native shrub, poison oak is more or less restricted to sandy soil, dry barrens, sand hills, oak-pine or pine woods, in New Jersey, Maryland, Tennessee, and southern Missouri south to northern Florida, Texas, and Kansas. It is not as common as poison ivy.

Poisoning: See $T$. vernix.

Toxicodendron radicans (L.) Kuntze (Rhus radicans L.)Poison ivy (Figure 3)

Description: Either a non-climbing woody shrub or a vine climbing along the ground, on low plants, or high in trees or on poles; leaves alternate, with three leaflets, each hairless

Figure 3. Poison ivy (Toxicodendron radicans) The infamous weed of the United States and Canada with the characteristic three leaflets. (See next page.)

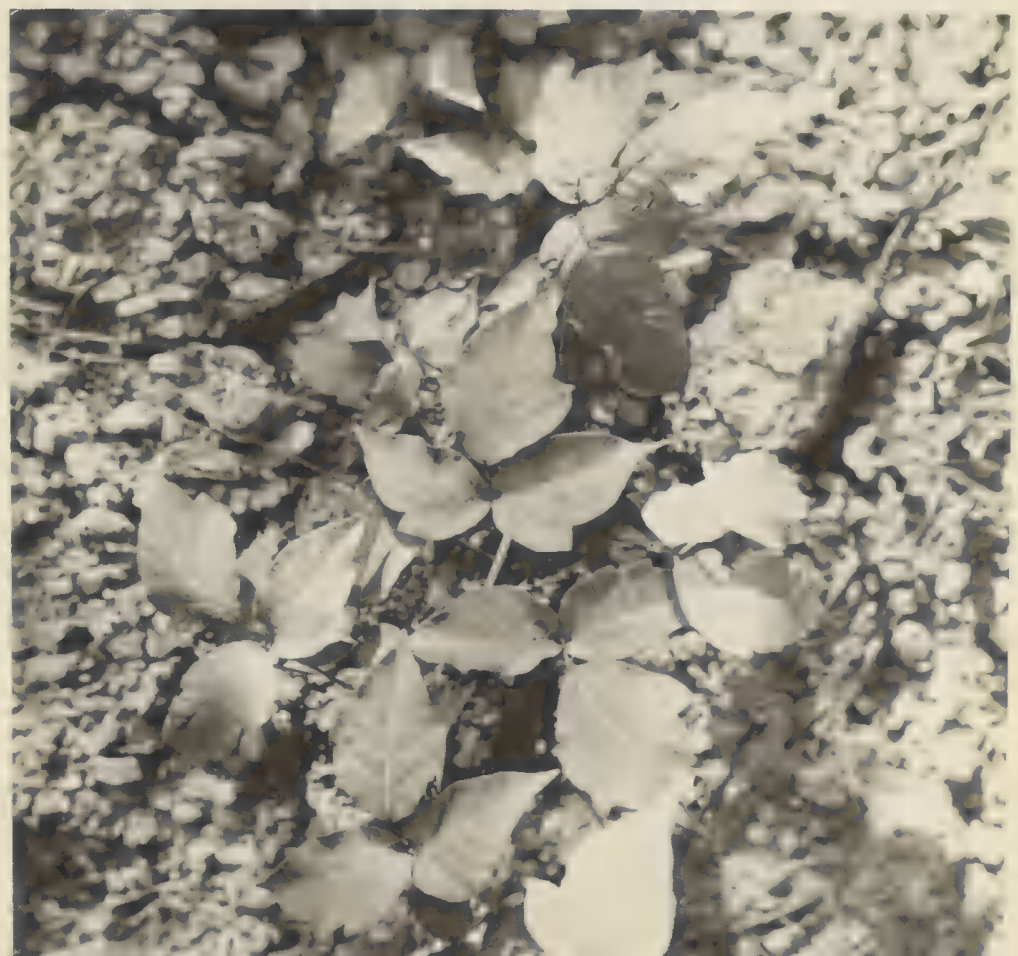




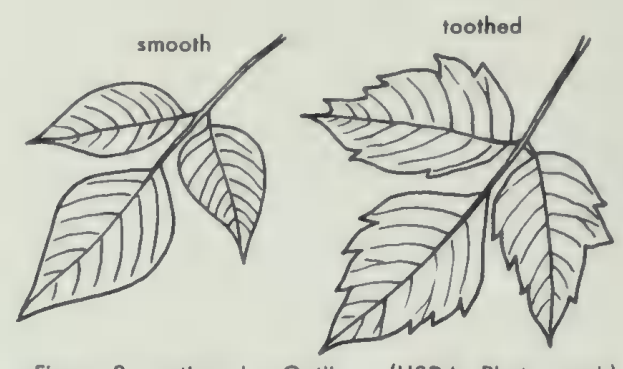

Figure 3, continued. Outlines (USDA Photograph) show variation of the leaflet margin; the lobed form is similar to poison ook.

or slightly hairy, the margin not toothed, with small teeth or variously lobed; flowers and fruits in hanging clusters, the fruit a yellowish drupe, not hairy.

Occurrence: Poison ivy is a native and extremely variable weed throughout southern Canada and the United States except the west coast. It is very common in disturbed places, on flood plains, along lake shores, edges of woods, stream banks, fences, and around buildings.

Poisoning: See $T$. vernix.

Toxicodendron vernix (L.) Kuntze (Rhus vernix L.)-Poison sumac, poison elder, poison ash, swamp sumac, thunderwood (Figure 4)

Description: Shrub 5-8 ft. tall, or a small tree to $25 \mathrm{ft}$. tall, with smooth light gray bark; leaves alternate, pinnately divided with 7-11 leaflets, leaf and leaflet stalks reddish; leaflets pointed, margin not toothed; fruits in hanging clusters, each a cream-yellow, hairless drupe.

Occurrence: Poison sumac is a native in bogs of the North (a shrub) and swamps and river bottoms of the South (a small tree). It is rare in the mountains and most common in the Great Lakes region and eastern Coastal Plain from New Hampshire to Florida and west to Texas.

Poisoning: Every year nearly two million people in the United States experience irritating or painful effects from direct or indirect contact with poison oak, poison ivy, or poison sumac. One out of every two persons is allergic in some degree. 
The skin irritant is present in the sap, which is found in the roots, stems, leaves, pollen, flowers, and fruits. The itchy or painful skin rash results from contact with the sap that is released by a bruised portion of the plant. The danger of poisoning is greatest in spring and summer when the sap is abundantly produced and the plant easily bruised.

In addition to direct contact with the plants, the irritant may be spread by dogs, cats, or other animals; by contaminated clothing, garden or yard tools, or sports equipment such as golf clubs, guns, or fishing rods; or by accidental eating of the fruits. The irritating chemical is not volatile, but droplets may be carried in smoke on dust particles or ash. It is therefore dangerous to be in the smoke from burning plants. The pollen is blown by wind, and it is possible for an extremely susceptible person to contact the poison merely by being near the plant when the pollen is in the air.

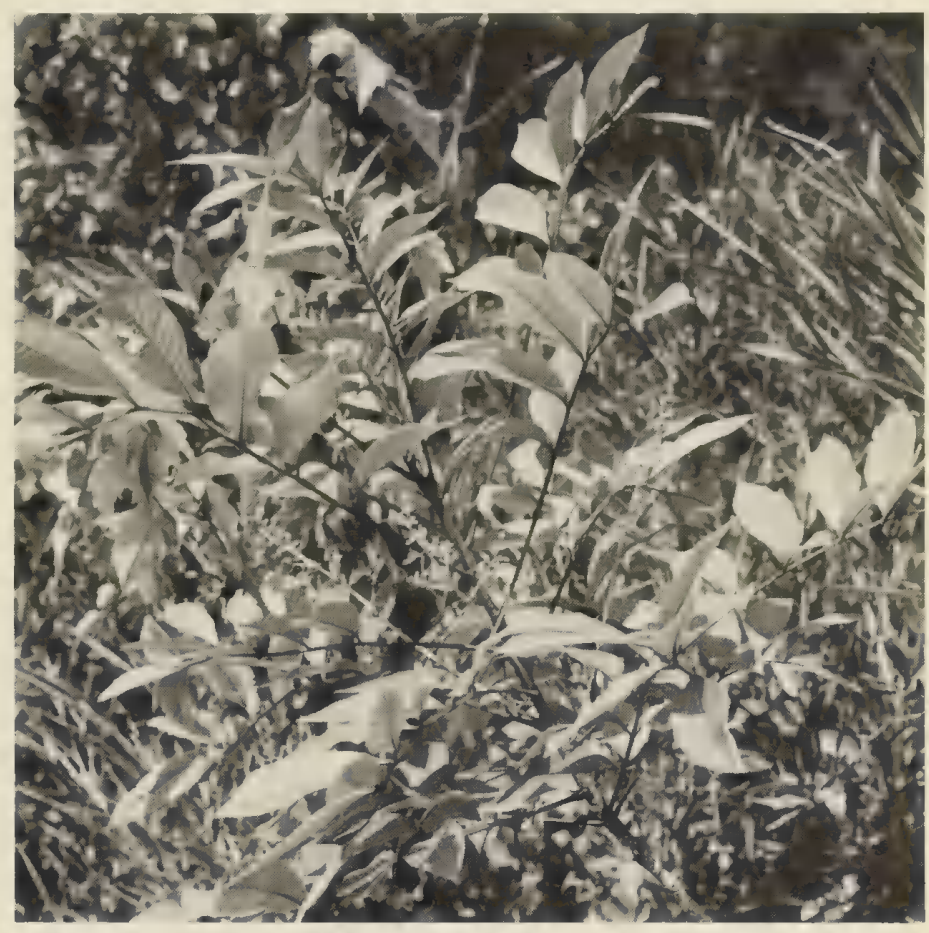

Figure 4. Poison sumac (Toxicodendron vernix) A poisonous shrub of bogs and swamps. 
After contact, the first symptoms of itching, burning, redness, and small blisters may appear in a matter of a few hours or may take as many as 5 days, depending on the individual. Severe dermatitis, with large blisters and local swelling may remain for several days and may require hospitalization. Persistent symptoms and apparent spreading are generally due to new contacts with plants or previously contaminated objects, or possibly by spread of the irritant from scratched affected skin areas and broken blisters. Secondary infections may occur when blisters are broken.

Proper identification and knowledge of the plants are essential in prevention. Eradication by means of digging or through chemical herbicides $(2,4-\mathrm{D} ; 2,4,5-\mathrm{T}$; amitrole; ammonium sulfamate) is the most effective means of eliminating repeated contact with plants around the home.

In case of contact, immediate washing with strong soap will often prevent the symptoms. If severe symptoms occur, see your physician.

Urtica dioica L.-Stinging nettle (Figure 5)

Description: Erect perennial herb similar to Laportea except for opposite leaves.

Occurrence: Stinging nettle grows along roadsides, in moist woods, and in waste places. It is nearly cosmopolitan either as a native or introduced weed. Related species of Laportea and also Hesperocnide are found in various areas of the United States and Hawaii.

Poisoning: The structure of the stinging hairs and the chemical irritants are the same as in Laportea.

\section{Phytophotodermatitis: Solar dermatitis from plants}

Numerous plants of wide distribution are thought to cause dermatitis by a combination of sunlight and contact with the plant, but proven photosensitization is rare. Two plants which contain furocoumarins and are known to cause phytophotodermatitis readily are the wild parsnip (Pastinaca sativa L.) and dittany or gas plant (Dictamnus albus L.). 
Phytophotodermatitis is frequently misdiagnosed as poison ivy or other contact dermatitis. The three prerequisites are moist skin from water or sweat, contact with the plant (direct or indirect), and then exposure to sunlight. Symptoms differ from contact dermatitis in that redness of skin and burning occur within 24 hours after exposure to plant and sun, and swelling and small to large blisters develop soon after. The intense residual redness persisting for months is diagnostic.

This type of dermatitis is not well known and may be more common than expected. Treatment of the symptoms would be the same as for contact dermatitis.

See Kingsbury (1964) for a discussion of photosensitization by plants. 


\section{INTERNAL POISONING}

Plants considered as "internal poisons" are those that cause a chemical or physiological disturbance, or death, when eaten. True poisoning of this type, unlike allergies or dermatitis, does not depend on a previous sensitivity of the individual. The term "poisonous" as used here does not necessarily mean "fatal," but that which causes any symptoms of toxicity.

Much folklore surrounds the subject of plant poisoning, yet only a small percentage of all the plants known causes toxic reactions. A few are mildly toxic and a very few can be extremely so and even fatal if eaten in sufficient quantity. Some plants are harmful only if eaten in certain stages of their growth, or only certain parts of the plant may be toxic. Other plants may be poisonous in all stages of development, and all parts may be equally poisonous. Thus the particular type of plant, the stage of growth, the part eaten, the season of the year, the amount eaten, or the condition, age, and size of the person who eats it may all be important factors in determining the potential hazard. To judge from past cases, "berries," mushrooms, seeds, leaves, stems, flowers, and roots can all be real hazards to man-particularly to children.

Toxic chemicals are commonly classified as: alkaloids, polypeptides and amines, glycosides, oxalates, resins and resinoids, and phytotoxins. Many others are unique and are found in specific plants. For a discussion of these chemicals and their actions, see Kingsbury (1964). 


\section{First aid: What to do in case of internal poisoning}

Call your physician immediately!

Be prepared to give him this information:

1. Name of plant if known.

2. How much and which parts of plant were eaten.

3. How long ago it was eaten.

4. Age of the individual.

5. Symptoms observed. All unusual symptoms should be carefully described.

6. A good description of the plant if the name is unknown. Save the specimen for later identification.

If a physician cannot be contacted

1. Have the individual drink a glass or two of water and then (if he is not unconscious or convulsive) try to produce vomiting by gagging the back of the throat with a finger or a blunt instrument (spoon, etc.), or by giving an emetic such as syrup of ipecac, warm salt water, mustard water, or soapy water.

2. Take the person to the nearest hospital emergency room or clinic. Be sure to take the plant along for identification if you have it.

3. The Poison Control Center in your area may be helpful if your physician is not available. These centers can provide information on proper therapy and may be able to aid in the identification of the plant. Locate the Poison Control Center for your area now. Telephone

For identification of the plant

1. Use the index of this book if name is known or look at the illustrations.

2. Contact a botanist (plant taxonomist, if possible) at the nearest university, college, or high school; county agricultural agents, soil conservation agents (USDA), or museum curators may also be able to identify the plant. 


\section{Common poisonous plants}

The plants included here are known, or strongly suspected, to have caused internal poisoning in humans. In addition, stock-poisoning plants could be harmful to children and adults if eaten in sufficient quantity. For a discussion of these see Kingsbury (1964) or a poisonous plant manual for your area, if available (see the Bibliography, pp. 148-153).

The fact that a plant is not mentioned in this book is no assurance that it is non-poisonous. Some uncommon ones have been omitted; others are yet to be recognized as dangerous.

The arrangement of the plants which follow is alphabetical by scientific name, within families arranged in a semievolutionary sequence from primitive to advanced. Any linear sequence such as this, however, is usually artificial in comparison to actual evolutionary relationships.

Common names of plants are unfortunately not standardized and can differ greatly among people within a region and between regions, which can lead to a great deal of confusion. Scientific names are standardized throughout the world and are given here for accuracy in linking the plant with the correct information on poisoning. A given plant species can have only one correct scientific name composed of two words followed by the name (or abbreviation) of the author who named it; for example, Gloriosa superba L. for the glory lily.

Occasionally scientific names are changed. For example, the well-known mistletoe of eastern United States has been known as Phoradendron flavescens for over a hundred years. Now we must change to Phoradendron serotinum. Why? Scientific name changes such as this are upsetting and discouraging to many people, yet the names of plants must conform rigidly with the International Code of Botanical Nomenclature and keep abreast of new and changing concepts in the science of botany. No name can be changed without a valid reason. In the case of mistletoe it was realized about ten years ago that flavescens was contrary to the Code and had to be changed to serotinum. In another case, poison 
oak and poison ivy are now considered sufficiently different from the sumacs (Rhus) to be called Toxicodendron. Therefore, rather than Rhus radicans for poison ivy we now find Toxicodendron radicans. Much printer's ink has been used denouncing "name changing" of well-known plants. Much less energy and adrenaline is expended learning the newer and more correct names than in resisting the changes.

The general habitat and distribution within continental United States and Canada is given for the native or naturalized plants. The presence of a plant in Alaska or Hawaii is noted separately. Cultivated plants have no specific distribution since many are now being grown outside their native climates in home greenhouses, on protected patios, or inside houses.

Notes on treatment are strictly intended for the physician alone, and any specific antidote should be administered only by a physician. Certain treatments, incorrectly given, could be as dangerous as the original poisoning. As will be noted, the treatment of plant poisoning is mainly symptomatic and supportive, and specific antidotes are neither available nor necessary except in rare cases.

Microscopic green plants known as algae are common inhabitants of surface water and are encountered in nearly all water exposed to sunlight for a period of time. While extensive growths of algae (blooms) may be a nuisance, most are not toxic. A few blue-green algae, however, may cause death to wild and domestic animals and illness or death to humans. Although poisoning of humans by algae seems fairly rare, some algae have been suspected as the possible cause of stomach and intestinal irritation among persons using a common water supply, or swimming in ponds with algal blooms. Water which is obviously polluted should be avoided.

Shellfish poisoning and the Redtide are caused by algae and have been serious problems on the Atlantic, Gulf, and Pacific coasts. 
In addition to mushrooms, numerous other fungi may be dangerous. Some of these, such as ergot, are found growing commonly on various cereal grasses. See Kingsbury (1964) for a discussion of fungal toxicity and ergotism.

Poisonous mushrooms, or toadstools, are undoubtedly the most famous of all poisonous plants, yet they still cause numerous illnesses and deaths each year. Surprising as it may seem in a time when mushrooms can be bought at a reasonable price, vacuum-packed and sterile or neatly boxed and perfectly safe, in any gleaming supermarket, thousands of mycophagists still gather them in the woods and fields and on lawns. And equally surprising, despite all published warnings, a dismaying number of adults - the unwary and the knowledgeable - still pick and eat poisonous forms during the damp summer season.

The common name "toadstool" (todesstuhl, death's stool) is often given to mushrooms that are poisonous, but there is no recognizable difference between the poisonous toadstool and the non-poisonous mushroom. In fact there is no simple rule of thumb for making this distinction, and if anyone claims to have a tried and true method he is fooling himself. All such methods may work for a few species, but not for all. Do not trust any of them, for all so-called tests are myths and foolish nonsense. Remember you are gambling with life and death!

There are old mushroom hunters

And there are bold mushroom hunters,

But there are no old, bold mushroom hunters.

There are several thousand species of mushrooms in the United States, but fortunately relatively few cause serious illness or death. There are three chief reasons for difficulties in distinguishing edible from poisonous forms. First, there are numerous species and the differences between them are rather subtle and require critical examination by the trained mycologist for correct identification. Second, many species 
are variable in their characteristics, and poisonous qualities may also vary depending upon the season, habitat, and geographical area. Third, poisonous and edible forms may not only look alike to the non-specialist but may grow together-even in the same fairy ring. In addition, the difficulties are magnified by variation in susceptibility among people.

No attempt will be made to describe the poisonous species, but a few of the more important and common types will be mentioned briefly. The common mushroom has a central stalk and cap at the top with flat plates (gills) on the lower surface of the cap (Figure 51). Rather than gills, some have minute pores in the lower surface of the cap. Puffballs differ by being more or less rounded without a stalk, and open at maturity by a hole at the top. The morels, another type of fleshy fungus, have a deeply ridged cylindrical top rather than a cap. There are poisonous species among all these types of fleshy fungi.

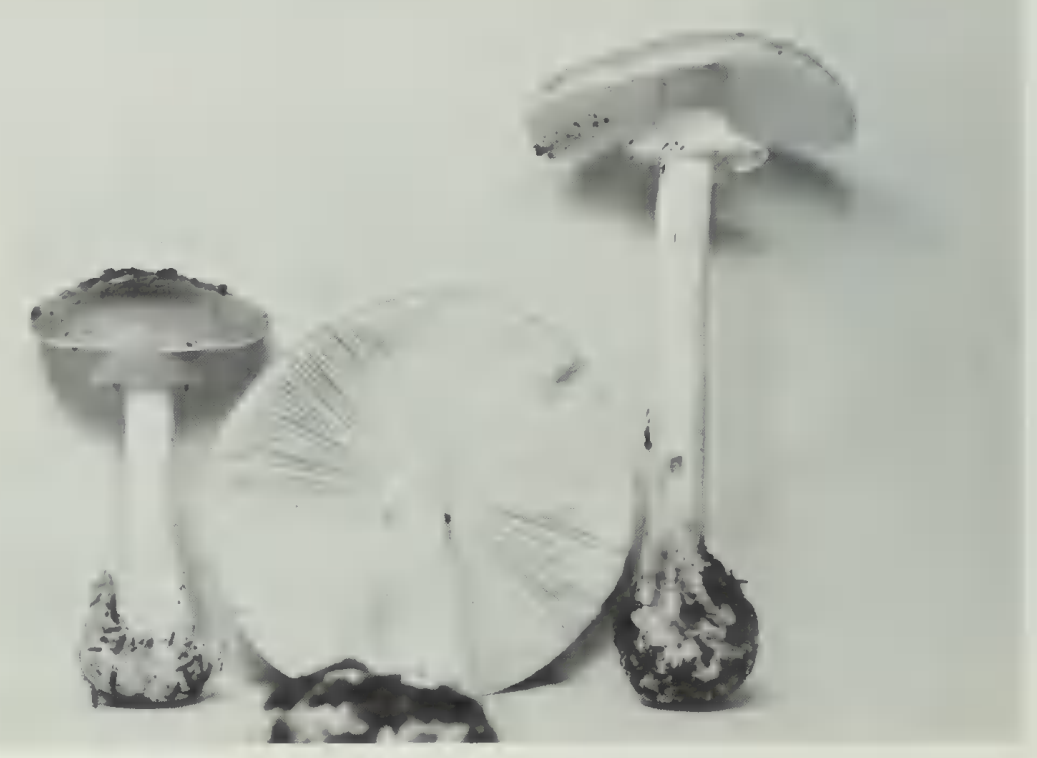

Figure 6. Destroying angel (Amanita verna) A deadly mushroom. Courtesy of Dr. L. R. Hesler. 
The amanitas are found very commonly in fairy rings on lawns and in woods. They cause about 90 per cent of the deaths due to mushroom poisoning. There are numerous species in the United States and Canada, some quite edible, many poisonous. It is safest to avoid them all. In case of amanita poisoning, one or two bites may be fatal. Two species are shown in Figures 6 and 7.

Clitocybe

The jack-o'-lantern mushrooms (Figure 8) usually grow in large dense clusters at the base of trees or individually. Some are edible; some poisonous.

Lactarius

The milky-caps have a milky juice which exudes freely when the flesh is broken. This is a large group of common mushrooms found chiefly in woods. Some are edible, but all

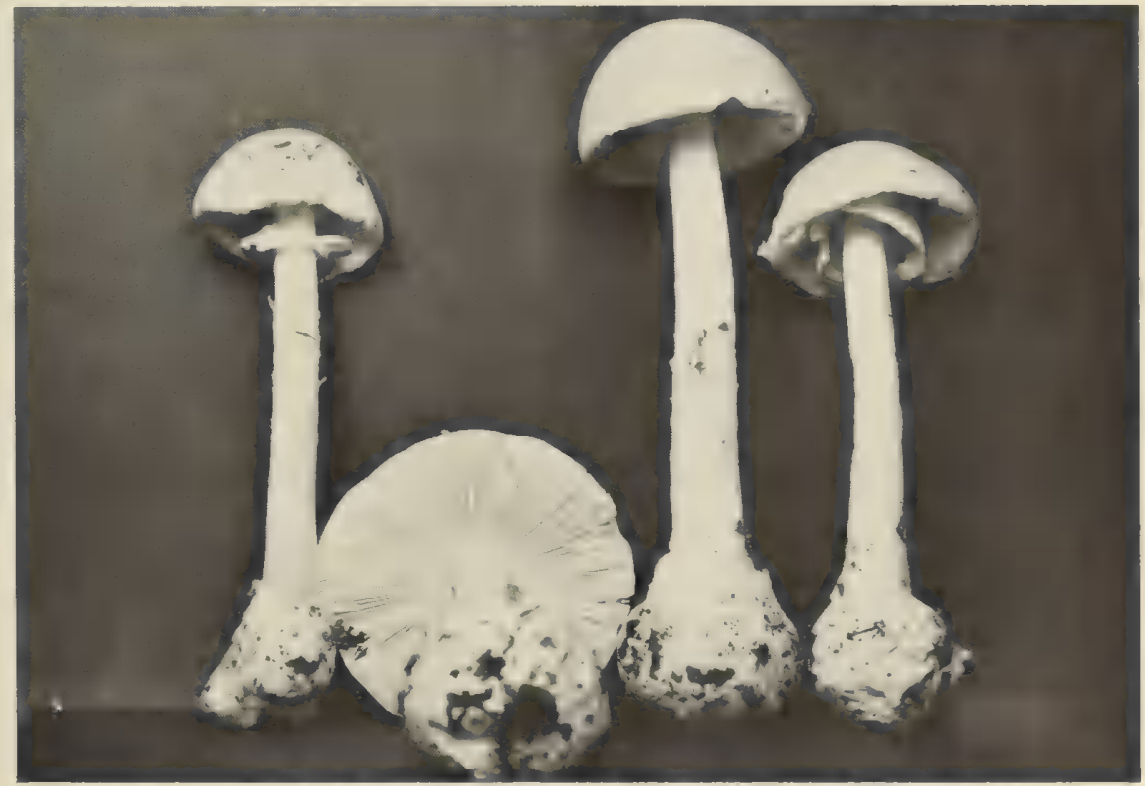

Figure 7. Browning amanita (Amanifa brunneseens) Poisonous mushrooms. Courtesy of Dr. L. R. Hesler. 


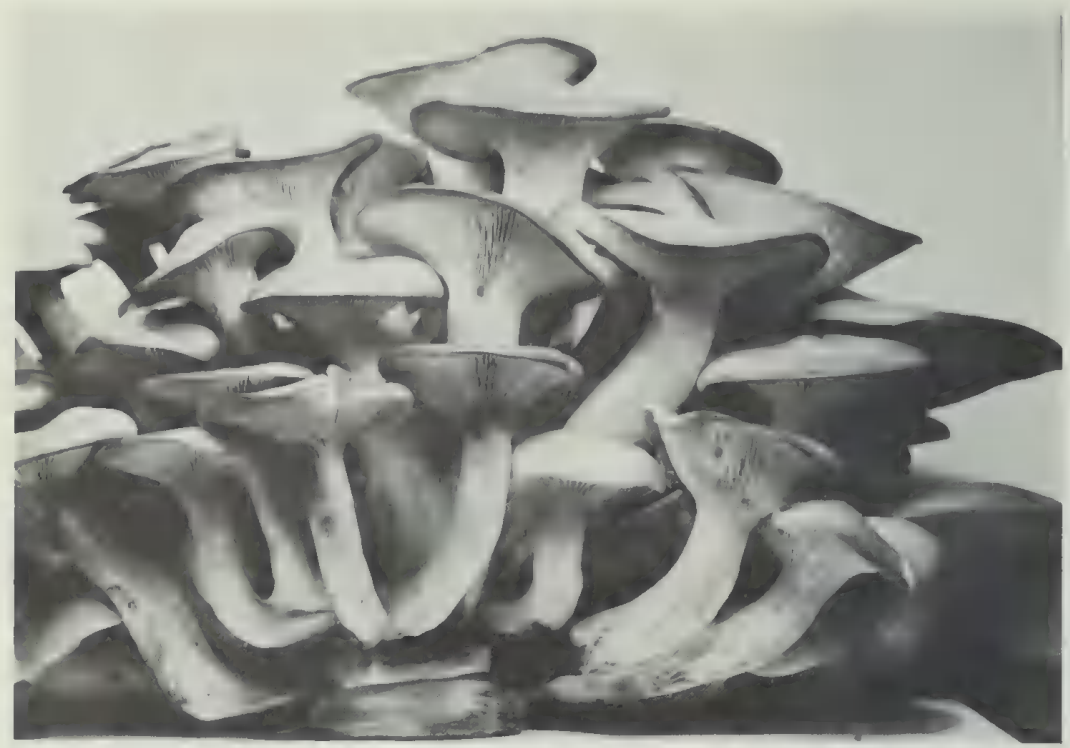

Figure 8. Jack-o'-lantern mushroom (Clitocybe illudens) A dense cluster of poisonous mushrooms. Photograph by Dr. L. R. Hesler, with permission of the University of Tennessee Press.

should be avoided. The milky juice, if tasted, may be mild at first, then quite acrid and peppery, lasting for some time.

Lepiota

The lepiotas are found very commonly in fairy rings on lawns and are very similar to amanitas. They are frequently large with the cap as much as 11 in. across. There are some edible species, but one of the very common types (Morgan's lepiota, Figure 9) causes many illnesses each year, and there are a few deaths on record. There is too much risk in trying to recognize the edible forms.

Russula

The russulas are quite common mushrooms which are white or often colored with red or purple caps. Some species are quite edible, some produce a very peppery taste, and a few are possibly poisonous.

Mushroom poisoning: The poisonous chemicals are either polypeptides in some or different alkaloids in others. The 


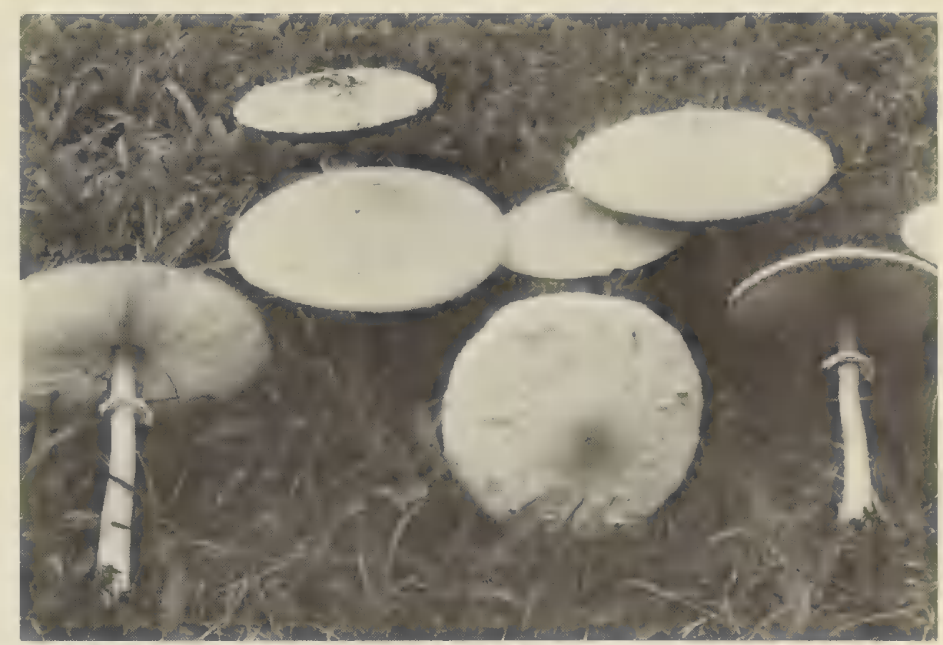

Figure 9. Morgan's lepiota (Lepioła molybdites) A common cause of mushroom poisoning. Photograph by Dr. L. R. Hesler, with permission of the University of Tennessee Press.

polypeptides are not destroyed by cooking. Symptoms may appear in either of two different forms. In one case there may be sudden stomach cramps, thirst, watering of eyes and mouth, sweating, difficult breathing, diarrhea, and vomiting. Mental disturbances, coma, and convulsions are also characteristic. In a second form there can be delayed symptoms (usually 6-24 hours) and a more deadly type of poisoning. This long asymptomatic period is often puzzling to the physician, and unless he is aware of this possibility an erroneous diagnosis and prognosis may be made. Vomiting and diarrhea are similar to the first type, and in addition liver damage and failure may result. Circulatory failure and coma usually follow within 2-10 days depending on the amount eaten.

The delicate and delicious taste of many mushrooms is not really worth the tremendous risk taken by eating wild forms.

To the physician: Gastric lavage (1:2000 tannic acid or 1:10,000 potassium permanganate solution) or an emetic; atropine; corticosteroids; peritoneal dialysis in serious intoxication; symptomatic and supportive. 
Eating of young fern "fiddleheads" or "crosiers" in salads or as a hot vegetable is fairly popular in some areas. Although some ferns are poisonous to livestock, none has been suspected of causing human poisoning. The picking of wild ferns should be restricted to those known to be edible in a particular region, and extreme caution should be taken not to confuse the young "fiddleheads" with young plants of the deadly poison hemlock or water hemlock.

\section{CYCADS-Cycadaceae}

Zamia spp. (Coontie, Florida arrowroot)

These are evergreen, fernlike, low plants with an underground stem and terminal female cones bearing orangeyellow naked seeds. They are found in dry sandy pinelands in Florida and are cultivated elsewhere in southern United States and Hawaii. Related cycads (Macrozamia, Cycas, Dioon, Microcycas, and others) are also cultivated as ornamentals in southern United States, Mexico, and Hawaii.

The fleshy seeds are poisonous if eaten in quantity. Paralysis and death have occurred from eating the seeds of Cycas circinalis (fern palm, false sago palm, crosier cycas). The seeds and roots are used for food in some areas but the alkaloid is washed out first.

To the physician: Gastric lavage or emesis; symptomatic.

YEW FAMILY - Taxaceae

Taxus spp.-Yew, ground hemlock

Description: Evergreen shrubs or small trees with narrow leaves which are alternate, stiff, $1 / 2-1 \frac{1}{2}$ in. long; seed single, green, ovoid, and nearly surrounded (except at the top) by a scarlet fleshy tissue (aril).

Occurrence: There are primarily two species ( $T$. cuspidata Sieb. \& Zucc. and T. baccata L.) cultivated as ornamental shrubs. The native species of eastern United States are T. canadensis Marsh. of rich woods from Canada southward in the mountains to North Carolina and Kentucky and $T$. 
floridana Nutt. in rich woods of northwestern Florida. In western United States T. brevifolia Nutt. is found along mountain streams, gorges, and ravines below 7,000 ft. elevation from California to Alaska.

Poisoning: Most parts contain the poisonous alkaloid taxine, although the red aril around the seed is edible in small quantities. Symptoms from eating the leaves or seeds are diarrhea and vomiting, trembling, pupil dilation. difficult breathing, muscular weakness, and rapid collapse, coma. convulsions, and slow heartbeat; fatal if eaten in quantity.

To the physician: Gastric lavage or emesis; control pain with Demerol, otherwise symptomatic.

\section{BANANA FAMILY_Musaceae}

Strelitzia spp.-Bird-of-paradise

These small banana-like plants with showy birdlike flowers are occasionally cultivated in greenhouses, as house plants, or outside in Florida, Texas, California, and Hawaii. The leaves are straplike, and the colorful flowers (yellow and blue, white and purple, or blue and red) are clustered in a narrow boatlike leaf.

The 3 -angled capsule and seeds are poisonous and cause vomiting, diarrhea, dizziness, and drowsiness if eaten.

To the physician: Gastric lavage or emesis; symptomatic.

\section{LILY FAMILY-Liliaceae}

Colchicum autumnale L.-Autumn crocus, meadow saffron, naked ladies

Description: Bulbous plants with long narrow basal leaves appearing in the spring; flowers white or light purple, in clusters appearing in the fall after the leaves have withered. This is not the commonly cultivated spring crocus.

Occurrence: Autumn crocus is cultivated in gardens and lawns throughout the United States and Canada and has become naturalized in some areas. It is a native of England, Europe, and Africa.

Poisoning: The alkaloid colchicine and related compounds 
are found throughout the plant (leaves, flowers, seeds) although in highest concentration in the bulb. Children have been poisoned by eating the flowers. Eating of the bulb or flowers is followed by a burning pain in the mouth and kidney failure. Colchicine is used as a medicinal drug and also as an important tool in studies of plant genetics.

To the physician: Gastric lavage or emesis; shock therapy; symptomatic and supportive.

\section{Convallaria majalis L.-Lily-of-the-valley}

Description: Herbaceous perennial from a slender, running rootstock; leaves 2-3, basal, and to $1 \mathrm{ft}$. long; inflorescence a one-sided raceme of small, aromatic, nodding, white, bell-shaped flowers appearing in the early spring; fruit a red berry, but seldom forming.

Occurrence: This native of Eurasia is frequently cultivated in gardens or flower beds in the United States and Canada. It occasionally escapes near gardens. A related species $(C$. montana Raf.) is native in the rich woods of the high mountains of North Carolina, Tennessee, Virginia, and West Virginia.

Poisoning: Cardiac glycosides convallarin and convallamarin have a somewhat digitalis-like action causing an irregular heartbeat and stomach upset. Leaves, flowers, roots, and fruits are considered toxic.

To the physician: Gastric lavage or emesis; supportive; potassium, procainamide, quinidine sulfate, disodium salt of edelate ( $\mathrm{Na}_{2}$ EDTA) have all been used effectively.

Gloriosa superba L.-Glory lily, climbing lily, gloriosa (Figure 10)

Description: Slender herbaceous plant or vine from a thick tuberous rootstock; leaves alternate or appearing opposite, simple, 4-7 in. long and $1 / 2-1$ in. or more wide, with a terminal tendril-like tip; flowers on long stalks, 6-parted, each segment crinkled along the edges, yellow or red, turning upward, the 6 stamens and green pistil project downward; fruit an oblong capsule, 2-3 in. long. 


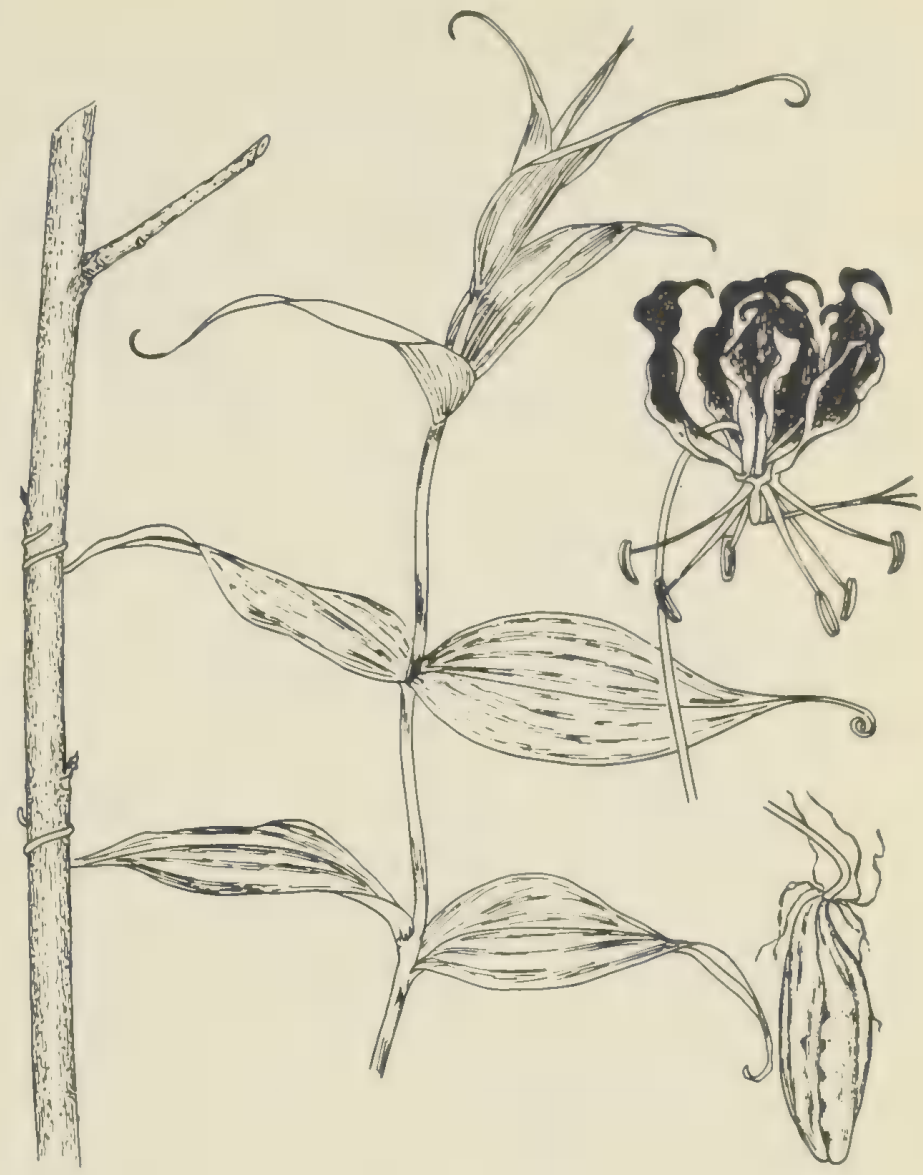

Figure 10. Glory lily (Gloriosa superba) A poisonous but attractive ornamental with upside-down flowers. Courtesy of the Florida Agricultural Experiment Station.

Occurrence: Native of tropical Africa and Asia, the glory lily is frequently planted outside in Florida and Hawaii and is grown as a potted plant elsewhere in the United States.

Poisoning: All parts, particularly the tubers, contain alkaloids which are extremely poisonous, causing numbness of lips, tongue, and throat, diarrhea and vomiting, burning in the mouth and stomach, difficulty of breathing, convulsions, and death.

To the physician: Gastric lavage or emesis; shock therapy; symptomatic and supportive. 
The common garden hyacinth of lawn borders, flower gardens, and pots inside the house can be dangerous if eaten in quantity. The bulb is the most dangerous part, causing intense stomach cramps, vomiting, and diarrhea.

To the physician: Gastric lavage or emesis; symptomatic.

\section{Ornithogalum umbellatum L.-Star-of-Bethlehem, snowdrop}

Description: Herbaceous perennial from a bulb; leaves basal, linear with a light green midrib; stem leafless, to $1 \mathrm{ft}$. tall; flowers white and starlike, perianth parts 6 , each with a green stripe on the back.

Occurrence: A native of Europe, this attractive plant is occasionally cultivated and has often escaped in waste places, roadsides, and lawns in the eastern and central United States, Canada, and Hawaii.

Poisoning: Various alkaloids are found in the bulb and aboveground parts and can cause nausea and intestinal disorders. Children have been poisoned by eating flowers and bulbs.

To the physician: Gastric lavage or emesis; symptomatic.

Veratrum viride Ait.-False hellebore, hellebore, Indian poke

Description: Herbaceous perennial, 3-8 ft. tall, from a thick vertical rootstock; leaves 3-ranked up the stem, 6-12 in. long and to 6 in. wide, oval, base sheathing the stem, with prominent veins and appearing pleated; flowers in a large terminal panicle with perianth parts 6 , glandless, greenish-yellow, and hairy.

Occurrence: False hellebore is a native of rich woods or along streams and wet areas, from eastern Canada to Minnesota and south along the mountains into North Carolina, Georgia, and Tennessee. V. parviflorum Michx., recognized by its hairless flowers and narrower upper leaves, is also poisonous and is found in the mountains from West Virginia to Georgia. V. californicum Durand has whitish flowers and is found in moist meadows and slopes in the mountains of the Pacific coast and the Rockies south to New 
Mexico. Additional species are found in Alaska and elsewhere.

Poisoning: Several alkaloids, such as veratrin, cause watering of the mouth, vomiting, diarrhea, stomach pains, general paralysis, and spasms. Severe cases may result in shallow breathing, slow pulse, lower temperature, convulsions, and death. An extract from the rootstock has been used for medicinal purposes, but known occurrence of human teratogens suggests that this is dangerous.

To the physician: Gastric lavage or emesis; activated charcoal; atropine, hypotensive drugs.

\section{Zigadenus spp.-Black snakeroot, death camas}

Description: Perennial herbs from a thick horizontal rootstock; stem to $3 \mathrm{ft}$. tall, smooth, leafy although most leaves are at the base; leaf blades narrow and grasslike, not stalked; flowers in terminal panicles, white or cream, the 6 perianth parts with 1-2 yellowish glands at the base on the upper side; fruit a 3-celled capsule.

Occurrence: Black snakeroot is frequent in open boggy or poorly drained areas. There are about fifteen species throughout the United States and Canada. It is assumed that all are more or less poisonous.

Poisoning: The alkaloids, such as zygadenine, are mainly concentrated in the bulb and cause muscular weakness, slow heartbeat, subnormal temperature, stomach upset with pain, vomiting, and diarrhea, and excessive watering of the mouth. Children have been poisoned by eating the bulbs and also the flowers.

To the physician: Gastric lavage or emesis; symptomatic, $2 \mathrm{mg}$. atropine subcutaneously and repeat as needed.

\section{AMARYLLIS FAMILY-Amaryllidaceae}

Narcissus spp.—Narcissus, jonquil, daffodil

This group of popular spring flowering plants so frequently found in yards and flowerpots may cause poisoning if eaten in quantity. The bulb is the most dangerous and will cause 
nausea, vomiting, diarrhea, trembling, convulsions, and may be fatal.

The related Amaryllis (Hippeastrum) and Crinum, both widely grown in warm areas for the attractive flowers, may also be dangerous.

To the physician: Gastric lavage or emesis; symptomatic.

\section{ARUM FAMILY-Araceac}

Dieffenbachia spp.-Dieffenbachia, dumbcane (Figure 11)

Description: Perennial herb with green stems 3-6 ft. tall; unstalked leaves large, oblong, green or often spotted, streaked, or mottled with white, lighter or darker green or yellow-green. There are many horticultural varieties with various color patterns of the leat. The two species generally grown are D. sequine (Jacq.) Schott and D. picta (Lodd.) Schott.

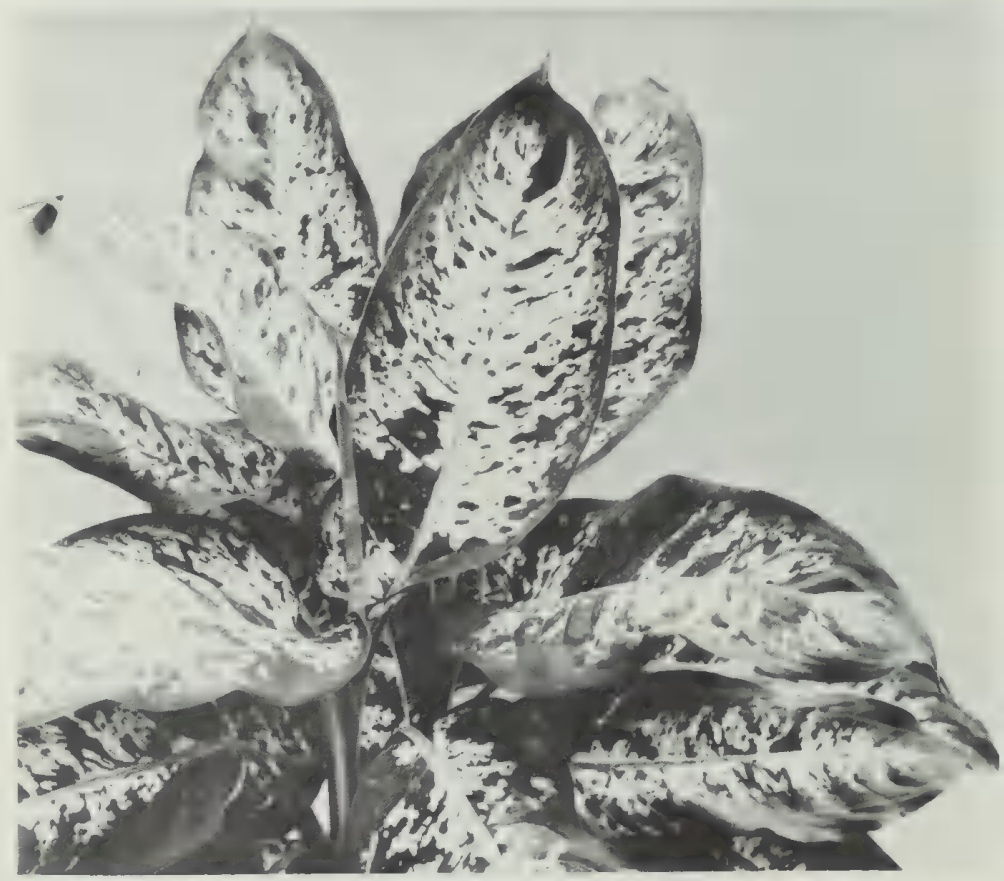

Figure 11. Dumbcane (Dieffenbachia sp.) An ornamental house plant with whitegreen variegated leaves. 
Occurrence: These are tropical American plants widely cultivated as house plants, or planted outside in southern United States and Hawaii.

Poisoning: Severe burning in the throat and mouth is caused to some extent by numerous needle-like crystals (raphides) of calcium oxalate, but primarily by a protein (enzyme) or asparagine. In very severe cases swelling of the mouth and tongue may cause choking. Symptoms of nausea, vomiting and diarrhea may indicate the presence of additional toxins, but the details are unknown.

To the physician: Gastric lavage or emesis; symptomatic; give demulcents; cold packs to lips and mouth, antihistamines or eminiphrine.

Other members of the arum family can be equally dangerous. The native and well-known Jack-in-the-pulpit, Arisaema triphyllum (L.) Schott, (Figure 12) found in rich woods throughout continental United States and southern

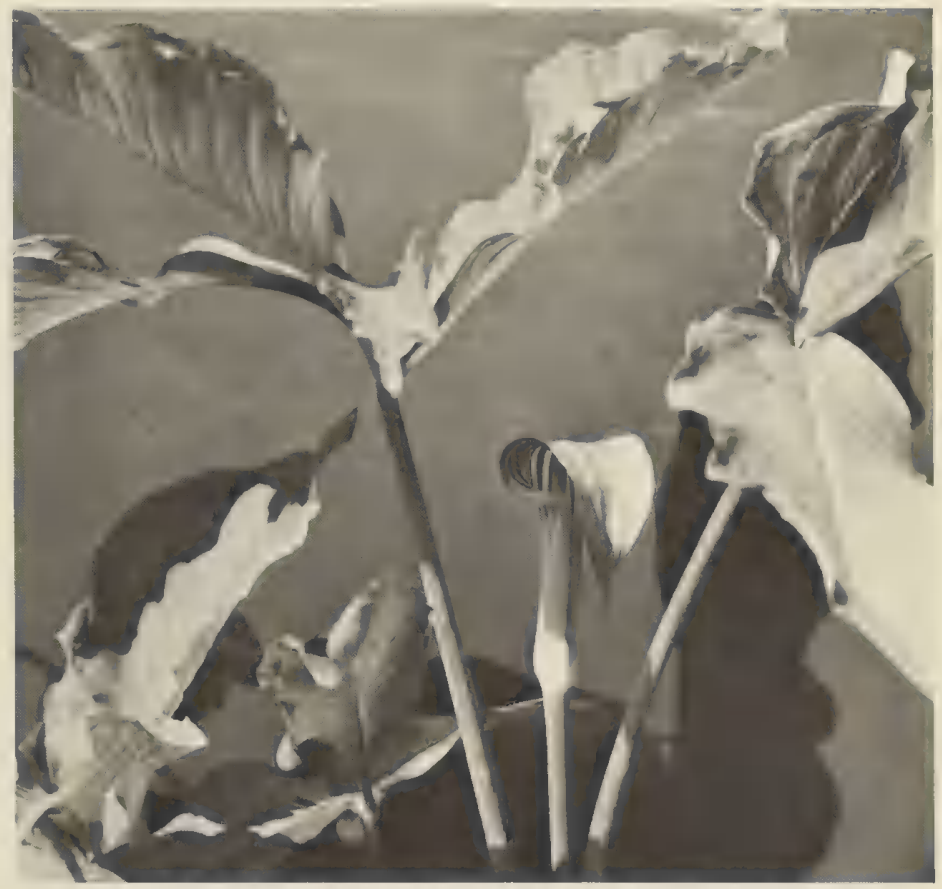

Figure 12. Jack-in-the-pulpit (Arisaema triphyllum) A well-known spring-flowering herb of rich woods with a dangerous root. 
Canada, can cause similar injury to the mouth if the roots are eaten in quantity.

Philodendrons (Philedendron spp.) are among the most popular ornamental house plants (vines) introduced from the tropics. There are numerous horticultural forms with various leaf shapes, including the "cut-leaf" philodendron or monstera. The leaves and stems are dangerous if eaten in quantity.

Other genera such as Alocasia, Colocasia (elephant ears), Caladium, Anthurium, and others are found in the warm areas of the country, Hawaii, and Mexico.

\section{PALM FAMILY - Arecaceae, Palmae}

\section{Areca catechu L.-Areca nut, betel nut}

Description: A very tall ( $75 \mathrm{ft}$.) and slender palm with feather-like leaves to $3 \mathrm{ft}$. or more long; fruit oblong, to 2 in., orange or red, the outside soft and fleshy.

Occurrence; Betel nut palm is frequently planted as an ornamental in Florida, Hawaii, and the American tropics. The nut is chewed by South American and Asian natives for the narcotic effect.

Poisoning: The alkaloids arecolin, arecain, and others found in the seeds can cause pupil dilation, vomiting, diarrhea, convulsions, coma, and death.

To the physician: Gastric lavage or emesis; symptomatic, $2 \mathrm{mg}$. atropine subcutaneously and repeat as needed.

\section{NUTMEG FAMILY-Myristicaceae}

\section{Myristica fragrans Houtt.-Nutmeg}

This tall tree, planted widely in the tropics, is the source of the commonly used mace and nutmeg. In recent years nutmeg has become more popularly known as a narcotica mild hallucinogenic drug similar in action to marijuana (see p. 70).

Poisoning: Eating of nutmegs (the seeds) causes, in addition to some initial hallucinations and elation, stomach pain, redness of skin, dry mouth, drowsiness, stupor, double vision, 
and delirium. As few as two nutmegs can be fatal.

To the physician: $2-4 \mathrm{oz}$. mineral or castor oil, followed by gastric lavage and demulcents.

\section{MOONSEED FAMILY - Menispermaceae}

Menispermum canadense L.-Moonseed, yellow parilla (Figure 13)

Description: A perennial, woody, twining vine; stem smooth; leaves alternate and palmately lobed with 3-5 low rounded lobes, the stalk usually twisted; flowers greenish white in small axillary clusters; fruit a drupe, globular, black with a whitish wax on the surface, appearing in grapelike clusters, but each with a single seed which is grooved and crescent-shaped. The fruits are often confused with grapes. Grapes, however, have many seeds (rather than 1) and the leaves have 20 or more large pointed teeth on the margin (rather than 3-5 rounded lobes).

Figure 13. Moonseed (Menispermum canadense) Vine with poisonous grapelike berries.

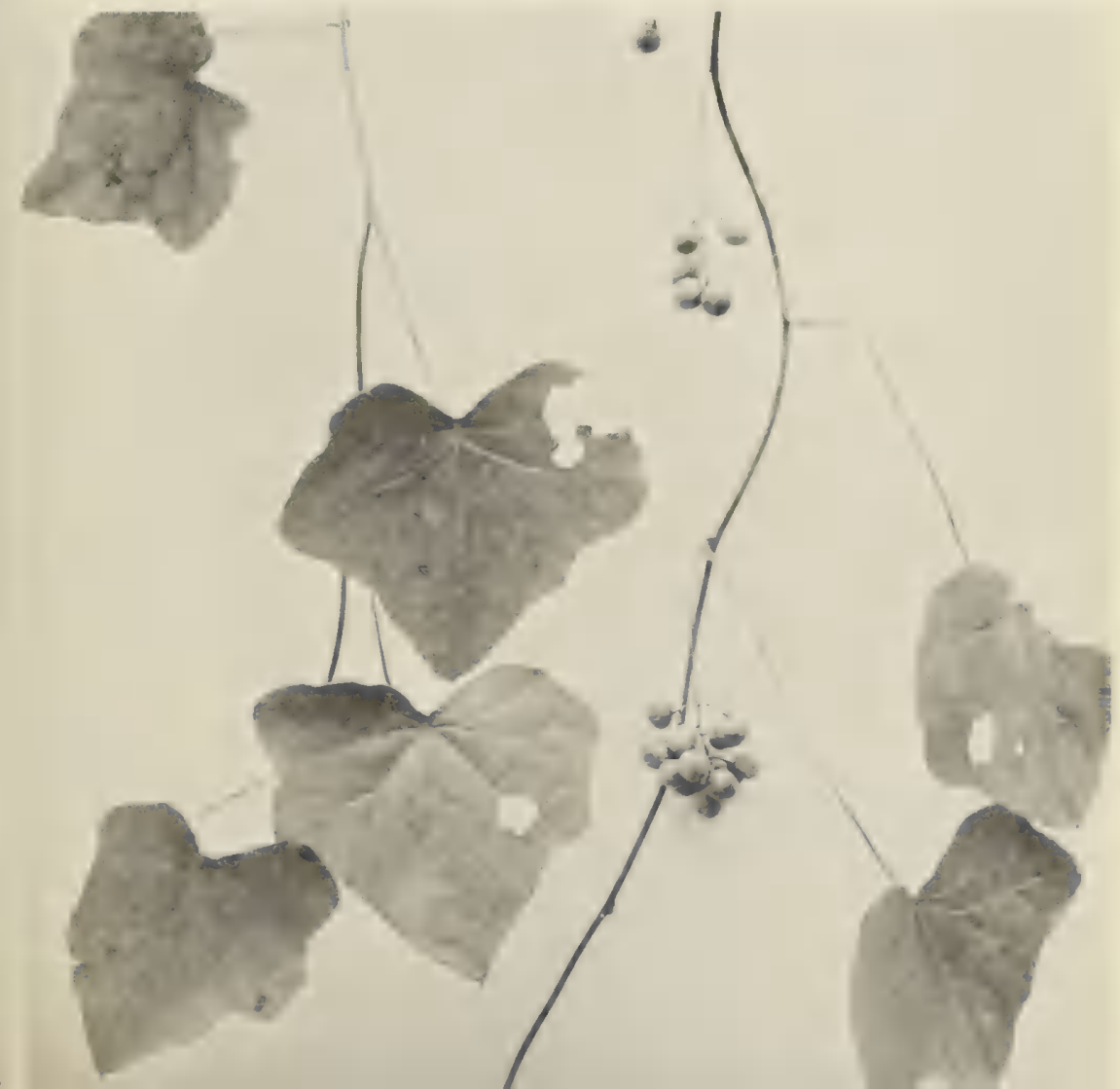


Occurrence: The moonseed vine is infrequent in moist woods and thickets from Canada south to Georgia and Oklahoma.

Poisoning: The fruits are dangerous if eaten in quantity. Birds eat these fruits readily, but contrary to popular belief what a bird eats is not necessarily safe for humans. Birds often feed without harm on fruits and seeds which are poisonous to other animals.

To the physician: Gastric lavage or emesis; symptomatic.

\section{BUTTERCUP FAMILY - Ranunculaceae}

\section{Aconitum spp.-Aconite, monkshood, wolfsbane}

Description: Perennial herb with ascending or nearly trailing stems; leaves alternate, palmately 3-9-lobed; flowers in terminal racemes or panicles, white to deep blue-purple, upper part hoodlike; fruit of 3-5 separate follicles.

Occurrence: $A$. reclinatum Gray (white flowers) and $A$. uncinatum L. (blue flowers) are native in rich woods, on slopes, and along creeks in the mountains and Piedmont of Georgia northward into Ohio and New York; A. columbianum Nutt. occurs in the high mountains and wet meadows in western Canada south to California and New Mexico. $A$. nepellus L. is European and commonly cultivated in gardens of the United States and Canada.

Poisoning: All parts of the plant contain the alkaloid aconitine and others. Symptoms are intense vomiting and diarrhea, muscular weakness and spasms, weak pulse, paralysis of the respiratory system, convulsions, and death in a few hours after eating the flowers, leaves, or roots.

To the physician: Gastric lavage or emesis; atropine, 2 mg. subcutaneously and repeat as needed; maintain blood pressure; artifical respiration.

Actaea spp.-Baneberry, white cohosh, snakeberry, doll'seyes, coralberry (Figure 14)

Description: Perennial herb to $3 \mathrm{ft}$. tall from a thick rhizome; leaf blades large, spreading, pinnately divided, leaflets with toothed margins; flowers small and white, in 
a long-stalked terminal raceme; thick-stalked, white-berried A. pachypoda Ell. ( $A$. alba of earlier authors), or thinstalked, red- or white-berried $A$. rubra (Ait.) Willd.

Occurrence: Baneberry is native in rich woods and occurs from Canada south to Georgia, Alabama, Louisiana, Oklahoma, and the northern Rockies. The red-fruited western baneberry ( $A$. arguta Nutt.) occurs from Alaska to central California, Arizona, Montana, and South Dakota.

Poisoning: All parts, but mostly the roots and berries, contain a poisonous glycoside or essential oil which causes acute stomach cramps, headache, increased pulse, vomiting,

Figure 14. Baneberry (Actaea pachypoda) Poisonous white fruit, or "doll'seyes," on swollen reddish stalks.

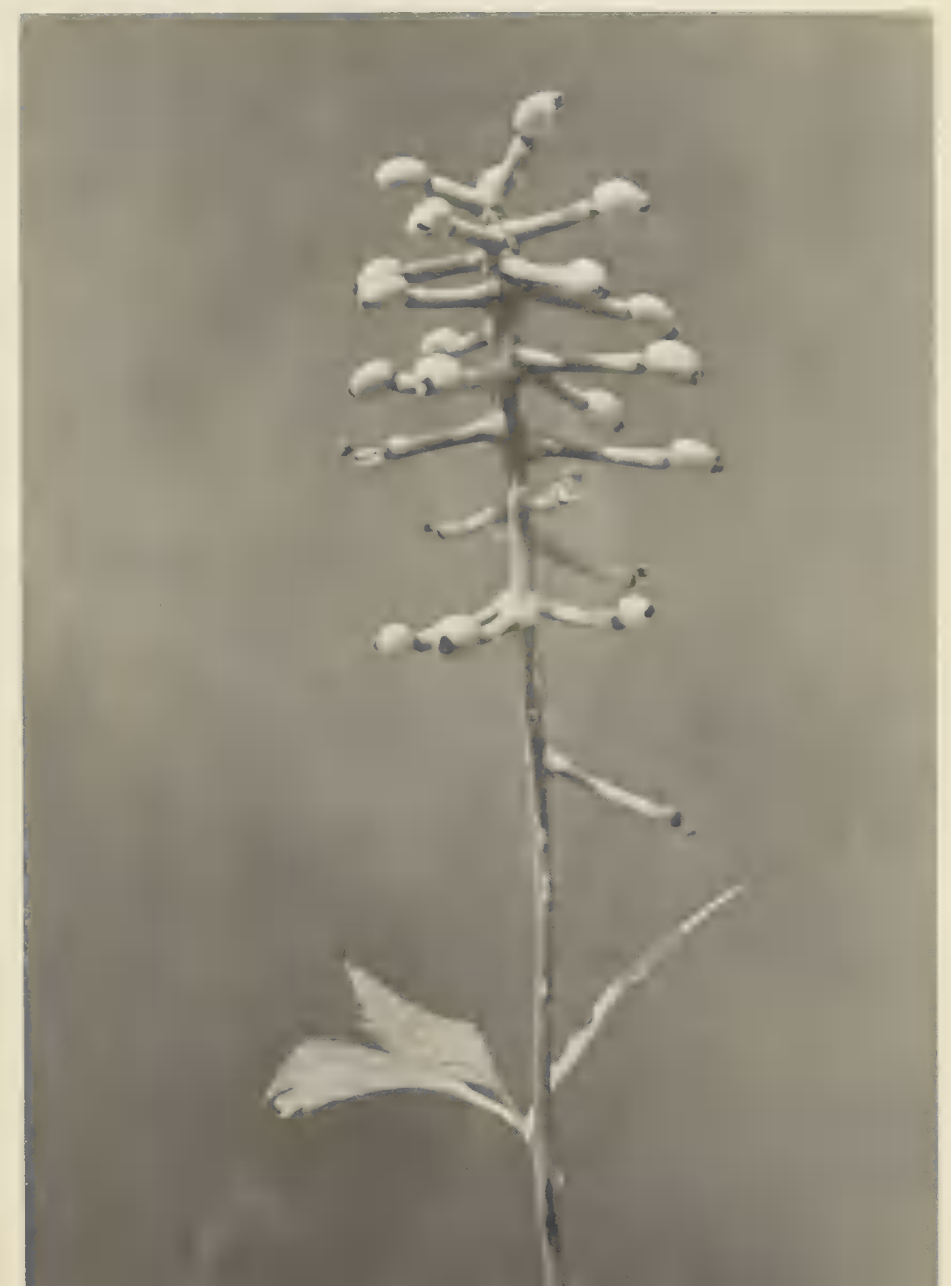


delirium, dizziness, and circulatory failure. As few as six berries can cause severe symptoms persisting for hours.

To the physician: Gatstric lavage or emesis; symptomatic and supportive.

Delphinium spp.-Delphinium, larkspur, staggerweed

Description: Annual or perennial herbs 2-4 ft. tall; leaves finely palmately divided and on long stalks; flowers in a terminal raceme, white, pink, rose, bluc, or purple; each flower with a spur projecting backward from the upper part; fruit a many-seeded follicle. The flowers may be double in some cultivated forms.

Occurrence: Larkspur is a native of rich or dry woods and rocky slopes throughout the country, but most common in western United States. These attractive plants are frequently cultivated in flower gardens.

Poisoning: The alkaloids delphinine, delphineidine, ajacine, and others are found mostly in the seeds and young plants. These alkaloids cause stomach upset, nervous conditions, depressions, and may be fatal if eaten in large quantities. Danger decreases as the plants become older.

To the physician: Gastric lavage or emesis; atropine, 2 mg. subcutaneously and repeat as needed; maintain blood pressure; artificial respiration.

Related plants which can cause similar poisoning are:

Adonis vernalis L.-Spring adonis, pheasant's eye

Popular cultivated ornamental.

Anemone spp.-Anemone, windflower, pasqueflower, thimbleweed

Native as well as cultivated.

Caltha palustris L.-Marsh marigold

Native in Canada, northeastern, and north central

United States.

Clematis spp.-Clematis, virgin's bower

Native and cultivated throughout.

Helleborus niger L.C Christmas rose

Cultivated ornamental. 
Hydrastis canadensis L.-Golden seal

Native in northeastern United States.

Ranunculus spp.-Buttercup, crowfoot

Native throughout the area.

\section{BARBERRY FAMILY-Berberidaceae}

Podophyllum peltatum L.-Mayapple, mandrake (Figure 15)

Description: Perennial herb with a creeping rhizome and thick fibrous roots; stem with 1 or 2 large, circular, 5-9lobed leaves; flower solitary, nodding in the axil between the two leaves, with perianth white or cream; fruit a fleshy berry, turning yellow when ripe.

Occurrence: Mayapple is a well-known spring flower of the rich woods and open fields and pastures throughout southern Canada and the United States. It is often found in large clusters of many plants close together.

Poisoning: The resinoid podophyllin is found in the rootstock, stem, flower, leaves, and unripe fruit and can cause severe diarrhea with vomiting. Cases of poisoning are rare for the fruit can be eaten without harm when completely ripe

Figure 15. Mayapple (Podophyllum peltatum) A well-known herb with a dangerous unripe fruit. From Flora of West Virginia, courtesy of Dr. E. L. Core.

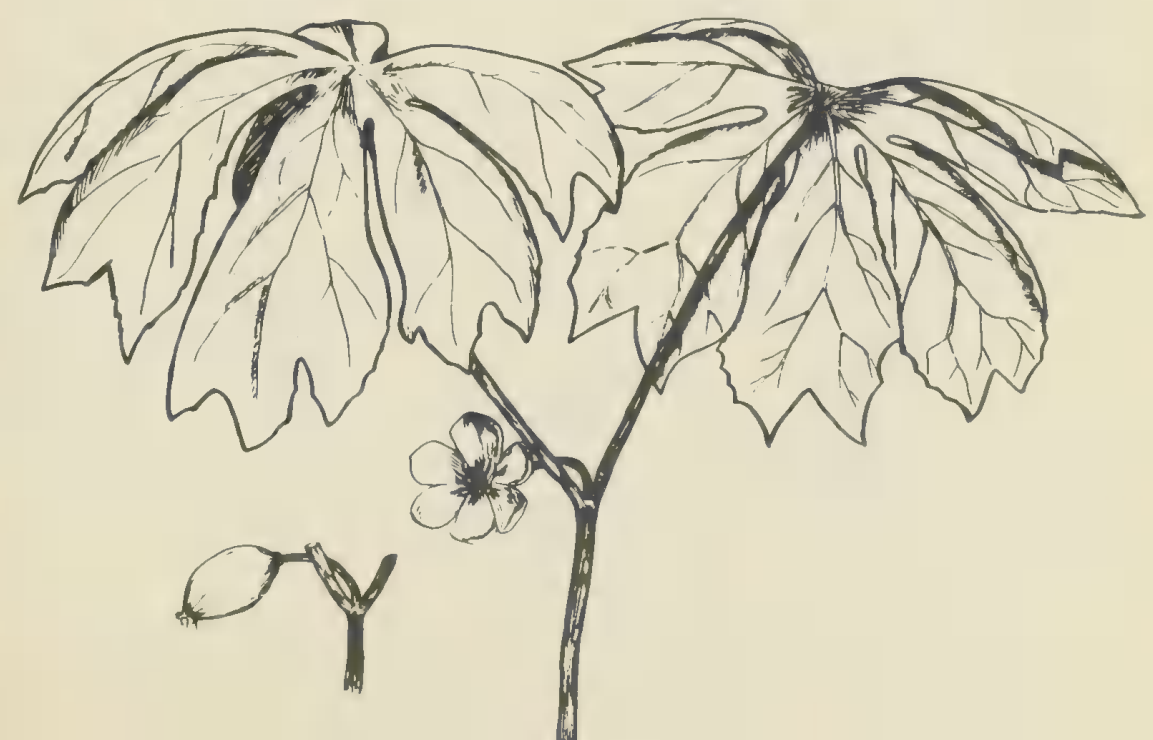


(yellow and soft) and if not eaten in quantity. Children have been poisoned by eating too much of the unripe fruit. An extract of the rootstock (podophyllin) is often used for medicinal purposes. Toxic effects on mitosis presumably could cause malformations in the human embryo, if taken by the mother during pregnancy.

To the physician: Gastric lavage or emesis; activated charcoal and antidiarrheal agents.

\section{Caulophyllum thalictroides (L.) Michx.-Blue cohosh}

Description: Perennial herb with a short knotty rootstock; stem simple, erect, bearing a large unstalked divided leaf and a raceme or panicle of small yellow-green or greenish purple flowers; the single ovary of each flower splits while young and exposes the 2 ovules, I of which develops into a dark blue naked seed.

Occurrence: This is a common plant of rich deciduous woods from Canada southward to Missouri and in the mountains and Piedmont to North Carolina and Alabama.

Poisoning: The leaves and seeds contain an alkaloid methylcytisine and also some glycosides which can cause severe stomach pains. Children have been poisoned by eating the bright blue seeds, although they are quite bitter to the taste. An extract from the rootstock is sometimes used for medicinal purposes.

To the physician: Gastric lavage or emesis; symptomatic.

\section{POPPY FAMILY_Papaveraceae}

Argemone mexicana L.-Mexican pricklepoppy, prickly poppy, thornapple

Description: An annual, whitish green herb with yellow juice; stem erect, usually branched, to $3 \mathrm{ft}$. tall; leaves alternate, thistle-like and prickly, the base of the leaf clasping the stem; flowers single and showy with 4-6 yellowish petals; fruit a prickly capsule opening near the top; seeds many and small.

Occurrence: Prickly poppy grows along fence rows and roadsides, in old fields and barnyards, and around buildings, 
in gardens and waste places. It is found from Florida to Arizona and northward into Pennsylvania and in Hawaii.

Poisoning: Various alkaloids (berberine, protopine, sanguinarine, and dihydrosanguinarine) are found in the leaves and seeds. Argemone has been a problem only when the seeds have contaminated home-ground corn, oats, or wheat. Symptoms are vomiting, diarrhea, difficulty of seeing, swelling throughout the body, fainting, and coma.

To the physician: Gastric lavage or emesis; symptomatic.

\section{Chelidonium majus L. - Celandine, rock poppy}

Biennial herb with reddish juice; flowers yellow. Celandine is a native of Eurasia and is established in moist soil from Canada to North Carolina and Missouri. Poisoning is the same as in Argemone.

\section{Papaver somniferum L.-Common poppy, opium poppy}

This erect annual with showy flowers and milky juice was once commonly planted in gardens and locally escaped in the United States. It is now unlawful to obtain, transport, or grow this species without a federal license. The common garden ornamentals are generally other species of Papaver.

Opium is a derivative of this species and comes from the juice of the young fruit. Poppy seeds used as topping of breads have only minute traces of the alkaloid and are not at all harmful. Eating the unripe fruit produces stupor, coma, shallow and slow breathing. The specific epithet somniferum, meaning "sleep bringing," indicates the long-known action of the extracts. Morphine and heroin, derivatives of opium, are the most vicious in their effects and claim an estimated sixty thousand addicts. Another derivative, commonly used to soothe colicky infants, is paregoric.

To the physician: Gastric lavage or emesis; strong coffee, support respiration, narcotic antagonists.

Sanguinaria canadensis L.-Bloodroot

Description: Flower white with many petals and conspicuous before the leaf unrolls; sap blood red.

Occurrence: Bloodroot is a very common and well-known 
spring wildflower of rich woods from southern Canada to Florida and Texas.

Poisoning: The sanguinarine, present throughout the plant, causes vomiting, diarrhea, fainting, shock, and coma. This same chemical is extracted from the rootstock and used as a medicinal drug.

To the physician: Gastric lavage or emesis; symptomatic.

\section{FUMITORY FAMILY_Fumariaceae}

Dicentra spp.—Dicentra, bleeding heart, Dutchman's breeches, squirrel corn, turkey corn (Figure 16)

Description: Glabrous perennial, short-stemmed herbs from a cluster of small tubers or a stout fleshy rootstock; leaves pinnately divided, the ultimate segments deeply lobed and very narrow; flowers white or pink, in a raceme or panicle; corolla 2 -spurred or saclike on the upper side; fruit a capsule.

Occurrence: There are a number of species native to rich woods in various parts of the United States and Canada; others are cultivated as garden or potted ornamentals.

Poisoning: The alkaloids protopine and others, found throughout the plant, cause trembling, staggering, convulsions, and labored breathing. Large quantities can be fatal.

To the physician: Gastric lavage or emesis; symptomatic.

\section{POKEWEED FAMILY-Phytolaccaceae}

Phytolacca americana L.-Pokeweed, pokeberry, poke, inkberry, pigeonberry (Figure 17)

Description: Large shrublike herb to $8 \mathrm{ft}$. tall, stem green to red or purple; leaves alternate, oblong, to $1 \mathrm{ft}$. long, decreasing in size toward the top of the plant, margin not toothed; flowers in a drooping or erect raceme, white; fruit a round, purple-black juicy berry, about $1 / 2$ in. across, drooping, or erect in $P$. rigida Small.

Occurrence: A native weed throughout eastern United States and southern Canada. It is common in open fields, along fences, roadsides, in waste places, and disturbed areas 


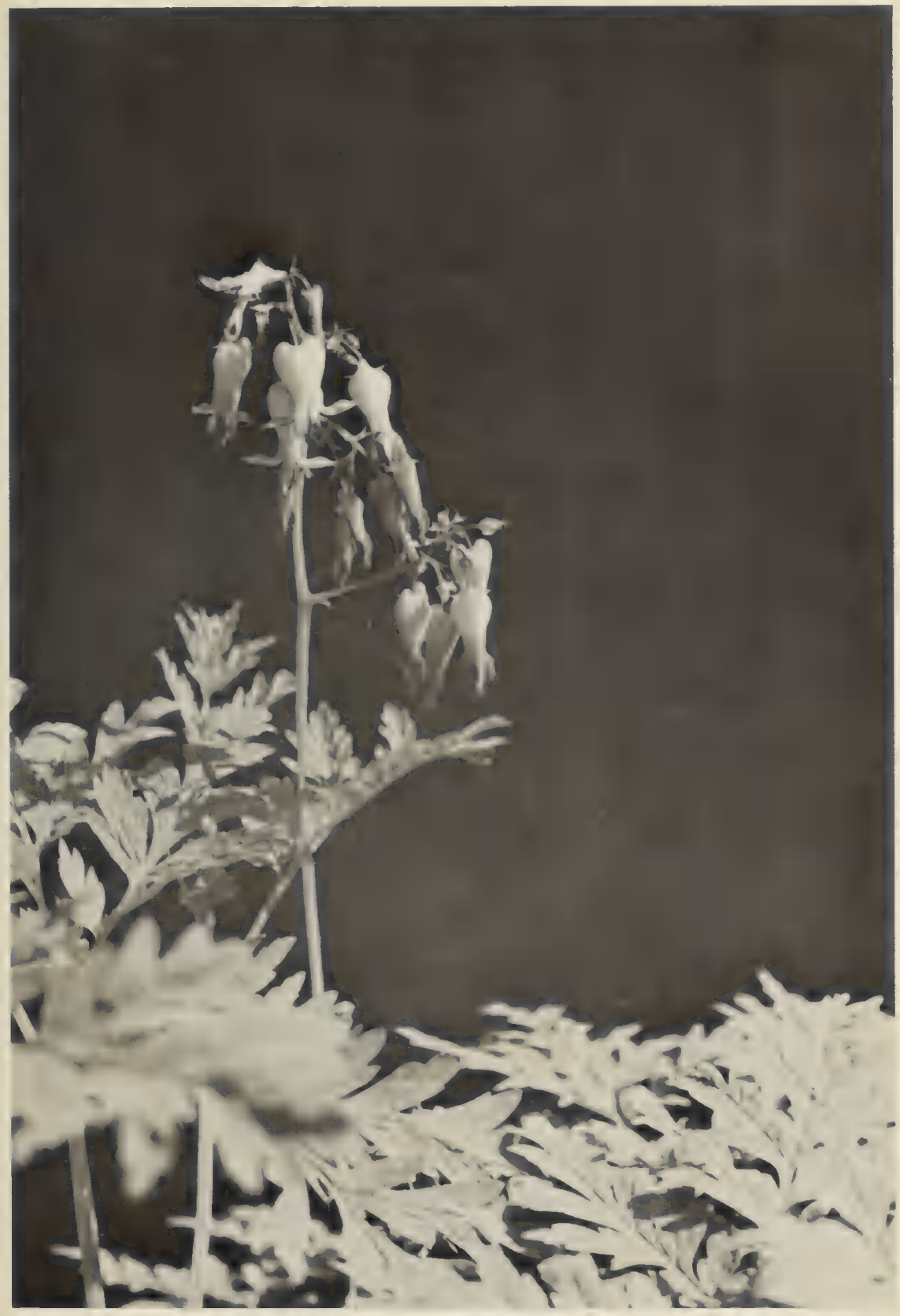

Figure 16. Bleeding heart (Dicentra eximia) A poisonous herb of flower gardens. 


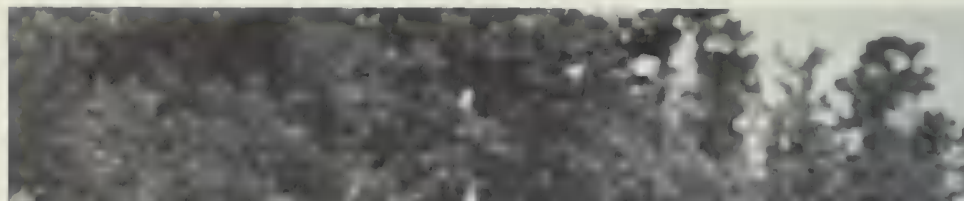

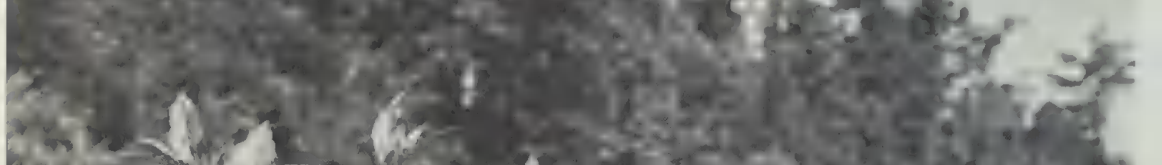
$\cos (-2)+1$

tor $x^{2}$

- $x-1 \times$

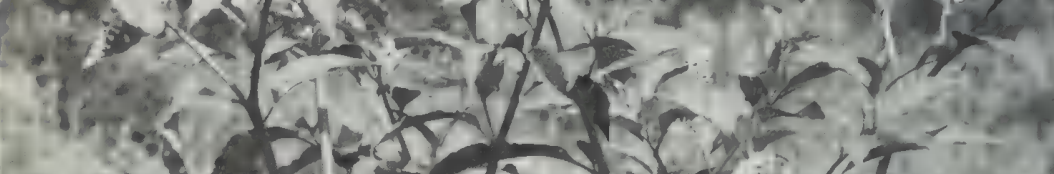

-

$47-i<-3$

-4

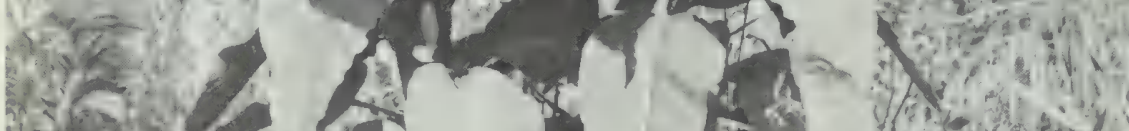
- 20 a 1 . - 5 - 19

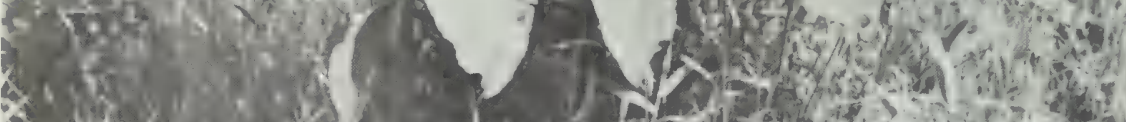

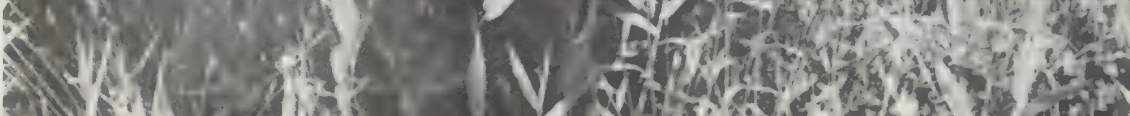

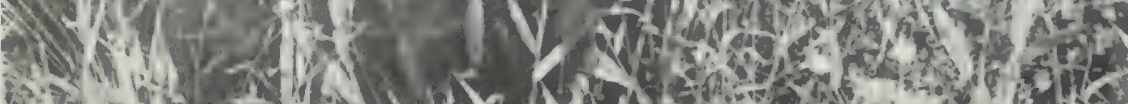

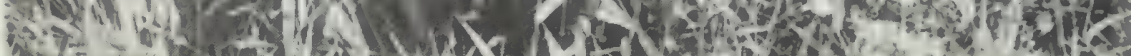
We she 

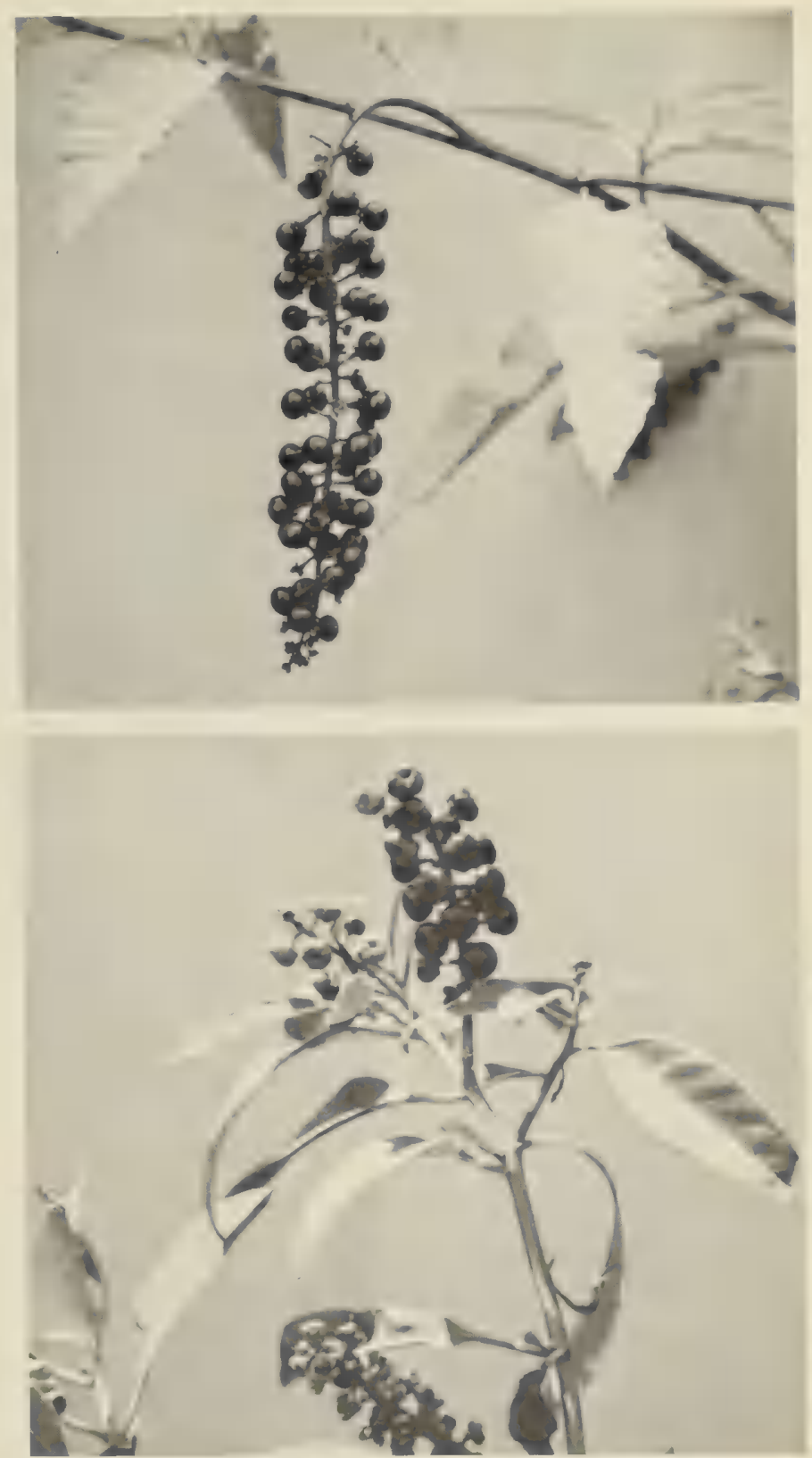

Figure 17. Pokeweed (Phytolacca americana) A common large weed of disfurbed areas; stalks of berries show difference between $P$. americana (top) and $P$. rigida (bottom). 
in general. It is also an occasional weed on the West Coast and in Hawaii. P. rigida is found along the coastal dunes and marshes from North Carolina to Texas and inland in Florida. Three additional species are found in Hawaii.

Poisoning: The poisonous principle is in highest concentration in the rootstock, less in leaves and stems, and least in the fruits. Eating of the poisonous parts causes severe stomach cramps and pain, nausea with persistent vomiting, diarrhea, slowed and difficult breathing, weakness, spasms, severe convulsions, and death.

Young tender leaves and stems of poke are frequently eaten as cooked greens. If thoroughly cooked (in two waters) the leaves are quite edible. Nevertheless, this is one of the most dangerous poisonous plants in the United States, because people eat the leaves without proper and complete boiling, or accidentally pull up the roots with the leaves. A few $(1-10)$ berries are generally harmless to adults and older children, although more than 10 can cause serious poisoning. Infants, however, can be seriously or fatally poisoned by eating a very few berries. Cooked berries are edible and used for pies without harm.

The roots and sometimes fruits are used as a source of a drug for medicinal purposes, but its usefulness is highly questioned.

To the physician: Gastric lavage or emesis; symptomatic and supportive. Peripheral plasmacytosis with potential immunosuppressive properties has been reported recently.

\section{PINK FAMILY-Caryophyllaceae}

\section{Agrostemma githago L.—Cockle, corn cockle (Figure 18)}

Description: Annual erect weed to $3 \mathrm{ft}$. tall with white silky hairs; leaves opposite, 2-4 in. long, narrow; flowers single, about 1 in. across, 5-parted with pink or purplish petals; fruit a capsule with many black seeds each with a pitted surface.

Occurrence: Corn cockle is native of Europe and is widely established in the United States and southern Canada as a weed in cultivated grain fields and waste places. It is 
sometimes cultivated as an ornamental annual. Because of the difficulty of screening the seeds from wheat, it is particularly common in wheat fields and from these has invaded roadsides and other disturbed areas. Highly contaminated wheat which cannot be sold causes annual losses of millions of dollars to wheat growers.

Poisoning: The seeds contain githagenin which causes severe stomach pain with vomiting and diarrhea, dizziness,

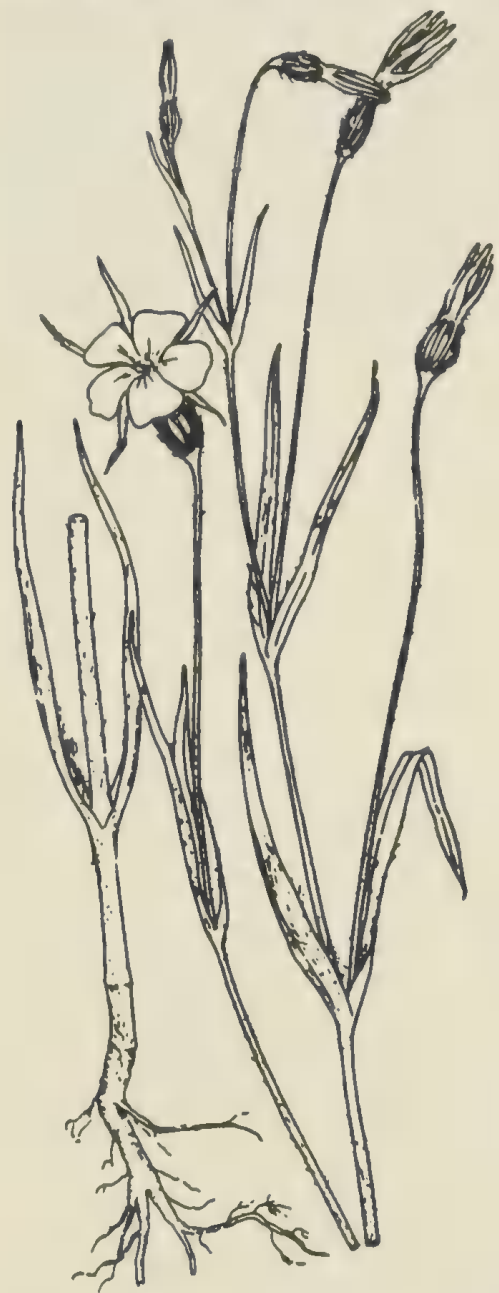

Figure 18. Corn cockle (Agrostemma githago) A frequent weed of grain Alelds with poisonous seeds. Courtesy of the Missouri Agricultural Experiment Station. 
weakness, and slow breathing. The seeds are of particular danger as a contaminant of home-ground corn, wheat, or oats.

To the physician: Gastric lavage or emesis; symptomatic and supportive.

\section{FOUR-O'CLOCK FAMILY - Nyelaginaceac}

Mirabilis jalapa L.-Four-o'clock, marvel-of-Peru

Description: An herb with erect, much-branched stems from 1-3 ft. tall; leaves opposite, deep green, stalked, ovate, $2-6$ in. long, pointed at the tip; flowers about 1 in. across, opening late in the afternoon or in very cloudy weather, white to red, yellow or striped, the 1-2 in. tubular portion 5-lobed at the top, and a 5-lobed calyx-like leaf at the base; fruit a leathery, 5-ribbed achene.

Occurrence: A native of tropical America and Mexico, four-o'clocks are cultivated in the United States as a favorite ornamental. They have escaped cultivation in parts of southern United States, California, and lower elevations of Hawaii.

Poisoning: The roots and seeds are the cause of acute stomach pain, vomiting, and diarrhea in children.

To the physician: Gastric lavage or emesis; symptomatic.

\section{CACTUS FAMILY-Cactaceae}

Lophophora williamsii (Lemaire) Coult._-Peyote, mescal, mescal buttons (Figure 19)

Description: A small (1-3 in. across) hemispherical, spineless, fleshy cactus from a large, branched perennial rootstock, and with low rounded sections each bearing a tuft of yellow-white hairs at the summit; flower from the center of the plant, small and white to rose-pink; fruit a pink berry when ripe; seeds black. The taste is very bitter and disagreeable.

Occurrence; A native of southern Texas and northern Mexico, it is shipped into other parts of the country as a narcotic. Peyote is recognized officially as a narcotic by some states, which makes it unlawful to possess any amount 


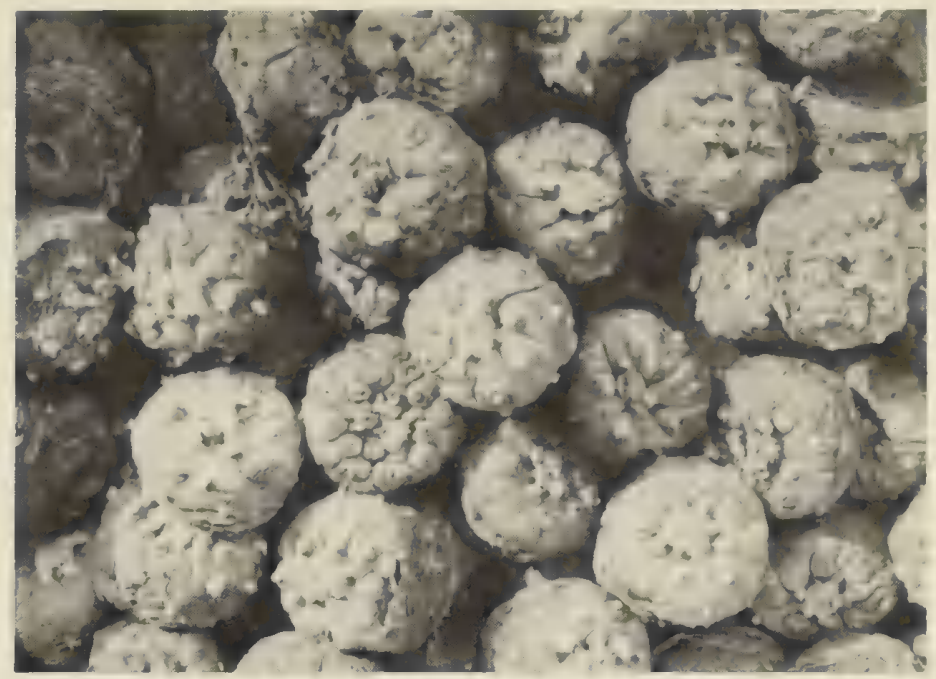

Figure 19. Peyore (Lophophora williamsii) A collection of "buttons." Courtesy of the North Carolina State Bureau of Investigation.

of the plant. Many states, however, have no legal restrictions at this time.

Poisoning: Peyote has long been used by Indians and other groups in their religious rites. The Aztecs considered it sacred, and it is still a sacramental feature of the Native American Church which claims two hundred and fifty thousand adherents among Indians of the western states.

Chewing fresh or dried pieces of the "buttons" (individual aboveground plants) produces illusions and hallucinations with extraordinary colored visions, but also headache, pupil dilation and blurred vision, muscular relaxation and dizziness, circulatory depression, loss of sense of time, wakefulness, and often severe stomach pain with vomiting and diarrhea. Several alkaloids (mescaline, lophophorine, etc.) are known, their action being somewhat similar to, although less potent than, the recently publicized LSD (lysergic acid diethylamide). It has been shown that peyote causes chromosome damage, as does LSD, making them extremely dangerous during pregnancy.

Unfortunately it has become popular for many, particularly 
high school or college students and the "hippie" society, to experiment with various hallucinogenic or psychedelic drugs - peyote, marijuana, LSD, etc. Although peyote may not cause a physiological addiction, the psychotic reactions and long-range effects are dangerous, and it can be psychologically habit forming. Peyote should be considered a dangerous poisonous plant and a narcotic in the legal sense.

To the physician: Early gastric lavage or emesis if thorough vomiting does not occur naturally.

\section{BUCKWHEAT FAMILY - Polygonaceae}

\section{Rheum rhaponticum L.-Rhubarb}

Rhubarb, commonly known for the edible leaf stalks (petioles), is quite poisonous if the leaf blades are eaten. Stomach pains, nausea, vomiting, weakness, difficulty of breathing, burning of mouth and throat, internal bleeding, coma, and death can occur. The poisonous substance is possibly a soluble oxalate with an additional unknown toxin.

Rhubarb is frequently grown in flower or vegetable gardens in northern United States and Canada and southward in the mountains to Georgia, Alabama, Colorado, and in Hawaii.

To the physician: Gastric lavage or emesis with lime water, chalk, or calcium salts; calcium gluconate; parenterally force fluids; supportive.

\section{BOXWOOD FAMILY-Buxaceae}

\section{Buxus sempervirens L.-Boxwood, box}

Description: Evergreen shrub with angular or winged stems; leaves simple, opposite, oval, $1 / 2-3 / 4$ in. long, leathery and dark green above and pale below with a whitish midrib.

Occurrence: Boxwood is cultivated extensively as a hedge or shrub in this country. There are many horticultural varieties as well as additional species in cultivation from the Old World.

Poisoning: The leaves and twigs contain buxene, which causes stomach pains, vomiting, and diarrhea. Large amounts 
may cause convulsions and death.

To the physician: Gastric lavage or emesis; symptomatic.

\section{SAXIFRAGE FAMILY - Saxifragaceae}

Hydrangea spp.-Hydrangea

Description: Shrubs to $10 \mathrm{ft}$. tall; leaves opposite and simple, elliptical, stalked, lobed or not, margins coarsely toothed; flowers in dense, rounded to flat-topped clusters to $1 \mathrm{ft}$. across; each flower white, pink, or blue, 4-5-lobed; sterile flowers, with an expanded calyx which is very showy and to $1 \mathrm{in}$. across, occurring at the periphery or throughout the cluster.

H. arborescens L.-Hydrangea, mountain hydrangea, sevenbark

These are native shrubs of dry or moist woods or rocky woods and hillsides, New York to Iowa, south to Florida and Arkansas. The flowers are white. There are a number of of native and cultivated varieties of this species.

H. macrophylla Ser--Hydrangea

This native of Japan, with many horticultural varieties, is commonly cultivated as an ornamental shrub for the large pinkish or blue flowers, or white, and in rounded clusters.

H. quercifolia Bartr.-Oak leaf hydrangea, sevenbark

This species is native in mixed forests of Florida, Alabama. Mississippi, Tennessee, and Georgia and is occasionally cultivated outside this native area. The flowers are white and the leaves are deeply lobed.

H. radiata Walt.-Snowy hydrangea, silverleaf

This is quite similar to $H$. arborescens (and often included with it) except for the back of the leaf, which is very white and hairy. It is limited to the southern Appalachians.

Poisoning: The leaves and buds contain hydrangin, a cyanogenic glycoside, which under certain conditions causes nausea, vomiting, and diarrhea. The roots are sometimes used as a source of a medicinal drug.

To the physician: Gastric lavage or emesis; treat for cyanide poisoning. 
Prumus serotina Ehrh.-Black cherry, wild cherry (Figure 20)

Description: Tree 15-60 ft. tall; bark of twig very bitter to taste; leaves alternate, simple, 1-5 in. long, deciduous, the margin finely toothed; leaf stalk with 2 glands at the upper end just beneath the blade; blade hairless and shiny above and hairless below except for hairs along lower part of midrib; flowers small, white, 5-parted with many stamens, in racemes; fruit a dark purple or black drupe.

Occurrence: Black cherry is a very common tree in woods and fields, along fence rows, and in waste places throughout eastern North America.

Poisoning: All parts, particularly bark, leaves, and seeds, contain the cyanogenic glycoside amygdalin which yields hydrocyanic (prussic) acid upon hydrolysis brought on by partial wilting. The fruit is edible if the seeds are discarded. Poisoning can lead to difficult breathing, paralysis of the voice, twitching, spasms, coma of short duration, and death. Cyanide poisoning can occur suddenly and without many obvious symptoms. Children have been poisoned by eating the seeds, chewing on twigs, and making "tea" out of the leaves. The bark and sometimes the dried fruit are used as a source of a medicinal drug.

Related species of Prunus may also be poisonous: cherry, cherry laurel or laurel cherry, plum, almond, peach-native and cultivated forms. Seeds of the common apple or crab apple (Malus spp.) are similarly poisonous.

To the physician: Gastric lavage or emesis; treat for cyanide poisoning.

Rhodotypos tetrapetala Makino-Jetbead, jetberry bush

This is a commonly cultivated shrub in the northern part of the United States. The shining black drupes, in clusters of 4 with 4 spreading jagged sepals below, persist into the winter and are quite attractive. The drupes contain amygdalin, as Prunus above.

To the physician: Gastric lavage or emesis; treat for cyanide poisoning. 


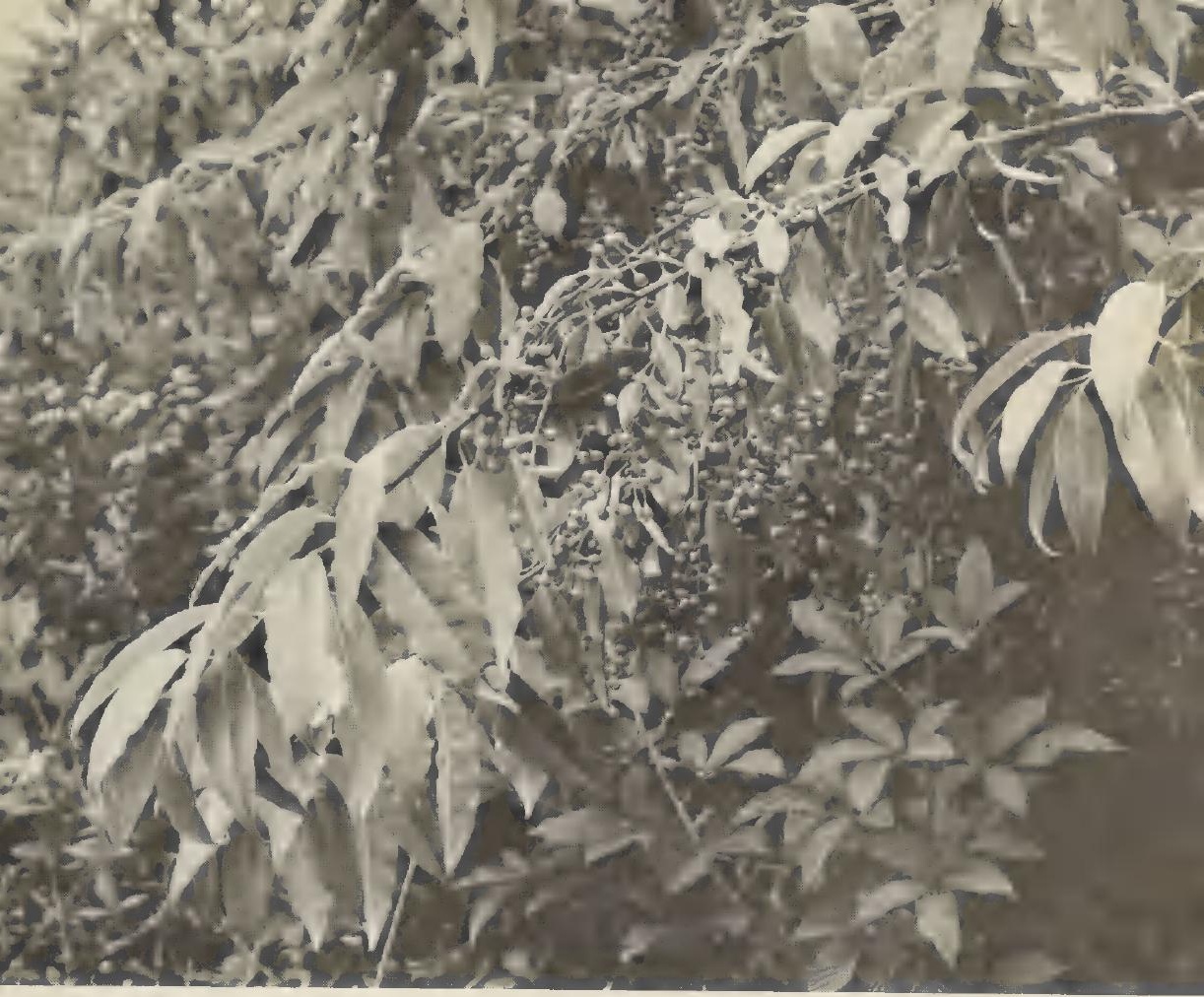

Figure 20. Black cherry (Prunus serotina) A common tree of eastern United States; small photograph below shows characteristic bark of the trunk.

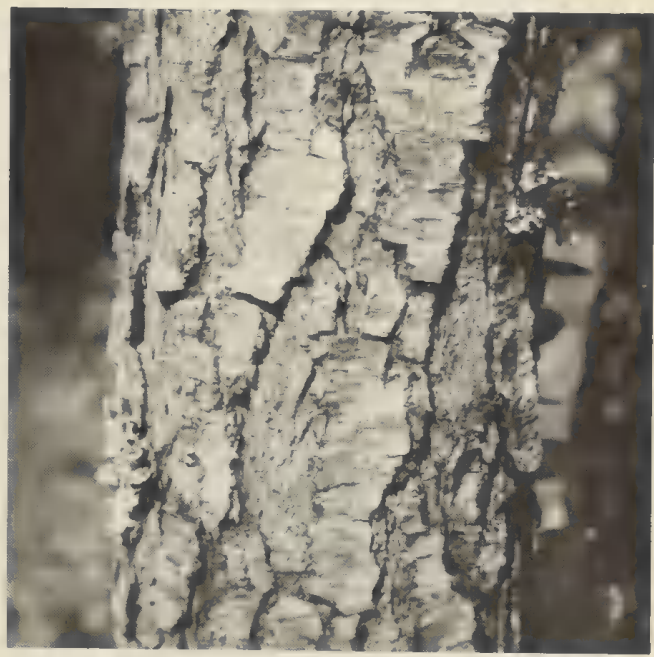


Occurrence: This deadly vine is occasionally found growing in central and southern Florida and the Keys in citrus groves and waste places as a weed. The seeds are so colorful and attractive that they are frequently used in rosaries, necklaces, leis, and various toys. They are sold in stores or brought back into the United States by those traveling in Central America, Mexico, the West Indies, or Hawaii. They are favorite playthings of children and therefore of extreme danger.

Poisoning: The seeds contain abrin, a phytotoxin, which causes severe stomach pain in 1-3 days, with nausea, vomiting, severe diarrhea, weakness, cold sweat, drowsiness, colic, weak and fast pulse, coma, circulatory collapse, and trembling. The seeds are harmless if not chewed because of their impermeable seed coat which prevents absorption of the chemical into the body. If the seed is thoroughly chewed, however, one seed is said to be fatal to a child. The poison can also be taken in through a pricked finger while stringing the beans.

To the physician: Gastric lavage or emesis; maintain circulation and correct for hemolytic anemia with blood transfusions; keep urine alkaline and treat for uremia; saline cathartics and control dehydration.

Daubentonia punicea (Cav.) DC.-Rattlebox, purple sesbane, false poinciana

Description: Deciduous shrub or small tree to $12 \mathrm{ft}$. tall; leaves alternate, 4-8 in. long, pinnately divided with 12-40 leaflets, each with a minute pointed tip and untoothed margin; flowers orange to red in drooping, axillary clusters near the ends of the branches; legume about 3 in. long, 4-winged, with a cross-partition between the seeds and not splitting open.

Occurrence: Native of Mexico and planted as an ornamental shrub, rattlebox has often escaped in various disturbed habitats in the southeastern United States Coastal Plain.

Related plants with poisonous seeds are Sesbania (sesban) and Glottidium (bladderpod, bagpod), found mostly in the southeastern United States along roadsides and in fields. 
Some sesbans are found in Hawaii and from California to Central America.

Poisoning: The seeds contain saponins which cause depression, diarrhea, and rapid pulse which may not develop until 24-48 hours after eating. In severe cases weakness, difficult breathing, and death can occur. The flowers also are poisonous if eaten.

To the physician: Gastric lavage or emesis; symptomatic.

Dolichos lablab L.-Hyacinth bean, lablab

Description: A twining vine with alternate, divided leaves each composed of 3 broad ovate leaflets, 3-6 in. long and sometimes equally broad, and rather abruptly pointed at the tip; flowers white, pinkish, or purple, in clusters of $2-4$ along a raceme, each flower $1 / 2-1$ in. long; legume flat, $2-5$ in. long with $3-5$ black or white seeds.

Occurrence: This vine is native of the Old World tropics but now is widely cultivated for food in South America and elsewhere in the tropics. Hyacinth bean has been introduced into North America as an attractive ornamental vine and has become naturalized in some areas, particularly in Hawaii.

Poisoning: The pods and seeds are cooked thoroughly (2-4 waters) for food in the tropics. Insufficient boiling causes poisoning from a cyanogenic glycoside.

To the physician: Immediate gastric lavage or emesis; treat for cyanide poisoning.

Gymnocladus dioica (L.) K. Koch-Kentucky coffee tree

Description: Large, rough-barked tree to $80 \mathrm{ft}$. tall; leaves alternate, to $3 \mathrm{ft}$. long, twice pinnately divided with leaflets ovate and margins untoothed; fruit a flat legume $3-6$ in. long with 4-7 flat broad seeds and sticky pulp between them.

Occurrence: This handsome tree is native in moist woods from Canada to Alabama and Oklahoma and is occasionally cultivated elsewhere in the United States as a lawn or street tree.

Poisoning: The legume, with the pulp between the seeds, can be confused with the more common honey locust 
(Gleditsia triacanthos), which also has pulp between the seeds but is not poisonous. The legume of the honey locust is much longer ( $8-15$ in.) and often twisted or curved and has sweet pulp and a thinner wall; honey locust is also typically thorny although there is a thornless variety. The seeds and pulp of the Kentucky coffee tree contain the alkaloid cytisine which causes stomach and intestinal disorders with diarrhea, vomiting, irregular pulse, and coma. The seeds have been used in the past as a substitute for coffee.

To the physician: Gastric lavage or emesis; activated charcoal, artificial respiration, and oxygen.

Laburnum anagyroides Medic.-Golden chain

Description: Shrub or small tree; leaves alternate, trifoliate, long-petioled; flowers golden yellow, in long drooping racemes; fruit a long flat legume.

Occurrence: The beautiful golden chain tree is native in southern Europe and is cultivated as an ornamental flowering shrub or tree, mainly in northern United States and southern Canada.

Poisoning: The flowers and seeds contain cytisine, which causes excitement, stomach and intestinal irritation with nausea, severe vomiting, and diarrhea, irregular pulse, convulsions, coma, and death if large quantities are eaten.

To the physician: Gastric lavage or emesis; symptomatic; activated charcoal, artificial respiration and oxygen.

Lathyrus spp.—Sweet pea, everlasting pea, vetchlings, singletary pea

Sweet peas are vines commonly cultivated for the showy flowers in erect racemes. They often escape cultivation in many areas. The seeds are poisonous and can cause paralysis, slow and weak pulse, shallow breathing, and convulsions. See Kingsbury (1964) for a review of lathyrism.

The wild sweet pea (Hedysarum mackenzii Rich.) of Alaska and Canada is reported as poisonous.

To the physician: Gastric lavage or emesis; symptomatic. 
Poinciana gilliesii Hook.-Poinciana, bird-of-paradise

This showy, non-spiny shrub is occasionally cultivated as a large potted plant, or outside in extreme southern United States and Hawaii. The leaves are alternate, with numerous very small leaflets; flowers light yellow with long red stamens, in a terminal raceme; fruit a legume to $3 / 4$ in. wide and 4 in. long. The green seed pods cause serious stomach and intestinal irritation if eaten.

To the physician: Gastric lavage or emesis; symptomatic.

\section{Pongamia pinnata Wight-Pongam}

This tree or woody climber from India is cultivated occasionally in southern Florida, southern California, and Hawaii. The leaves are pinnately divided with 5-7 pointed and stalked leaflets and hang from drooping branches; flowers lavender or pinkish, fragrant, and hang in clusters like wisteria; the short pointed woody pod generally contains a single seed.

The seeds and roots are considered poisonous and are used in parts of India to poison fish.

To the physician: Gastric lavage or emesis; symptomatic.

\section{Robinia pseudoacacia L.-Black locust (Figure 22)}

Description: A large tree with alternate, odd-pinnately divided leaves; leaflets 7-25, each oval or elliptical and with a smooth margin; 2 spines present at the base of the leaf stalk; flowers white, in drooping racemes; fruit a flat legume.

Occurrence: Black locust is a common tree in dry woods and along roadsides and fence rows in southern Canada, eastern and central United States. It is also naturalized in the Pacific states from Washington to central California.

Poisoning: Inner bark, young leaves, and seeds contain robin, a phytotoxin, and robitin, a glycoside, which cause dullness and depression, vomiting, diarrhea, weak pulse, and coldness of arms and legs. Children have been poisoned by sucking on fresh twigs, eating inner bark, and eating seeds.

To the physician: Gastric lavage or emesis; symptomatic and supportive, keep urine alkaline. 
Sophora secundiflora (Ort.) Lag. - Mescal bean

Description: Evergreen shrub or tree to $40 \mathrm{ft}$. tall; leaves stalked, alternate, 4-6 in. long, pinnately divided with 7-9 leaflets, shiny yellow-green above and silky below when young; pealike flowers violet-blue, very fragrant, and about 1 in. long, in 1 -sided racemes; legume woody and white-hairy, the seeds $1 / 2$ in. long and bright red.

Occurrence: The mescal bean is found on ranges, hills, and in canyons from southwestern Texas and New Mexico into Mexico, and is grown widely in southern United States for its graceful foliage and attractive flowers.

Poisoning: The seeds contain poisonous alkaloids which cause vomiting, diarrhea, excitement, delirium, and coma. One seed, thoroughly chewed, is sufficient to cause death in a child. These have long been used as a medicine and narcotic by Indians in Mexico and the southwest.

To the physician: Gastric lavage or emesis; symptomatic.

Vicia faba L.-Fava bean, broad bean, horse bean, English bean, Windsor bean

Description: An annual vine; leaves alternate, divided with 2-6 leaflets, each $2-4$ in. long, without tendrils; flowers dull white with purplish blotch in center, one to several in the leaf axils; fruit a long legume, to 12-14 in., thick and angled and with many seeds; the seeds flattened and angled or nearly globular, brown to green, purplish, or black.

Occurrence: This plant is widely and commonly cultivated as an ornamental vine in various areas of southern United States. The fava bean is a native of Europe and is often grown for food in some areas. The beans are appearing on the United States markets both canned and frozen.

Poisoning: The beans (seeds) raw or cooked can cause severe hemolytic anemia appearing 2-3 days after eating. This condition, known as "favism," produces a profound anemia, headache, dizziness, diarrhea, nausea and vomiting, abdominal pain, fever, and death in some cases. Inhalation of pollen from the flowers can cause headache and dizziness 
in 2-3 hours. Favism is found only in certain individuals of the Negro race (about 10 per cent) and in about 1 per cent of white Caucasians of Greek or Italian origin. This inherited trait has been known for centuries and is characterized by a deficiency of an enzyme known as G-6-PD (glucose-6phosphate dehydrogenase). It is most serious in children and most common in boys. The beans may be eaten without danger by those not carrying this genetic trait.

To the physician: Gastric lavage or emesis; blood transfusion if necessary; keep urine alkaline.

Wisteria spp.—Wisteria (Figure 23)

The wisteria vine, or shrub or small tree in some cultivated forms, is commonly cultivated and is often escaped mainly in the southeastern United States. The pealike flowers are white to purple in large, showy, drooping racemes. The seeds and pods have been found to cause stomach and intestinal disturbances with repeated vomiting, stomach

Figure 23. Wisteria (Wisteria sinensis) A beautiful and popular vine of the southeastern United States; on the right, pod with poisonous seeds.
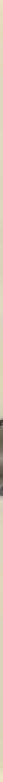
pain, diarrhea, and collapse. Two seeds are sufficient to cause serious illness in a child.

To the physician: Gastric lavage or emesis; symptomatic.

\section{MULBERRY FAMILY-Moraccac}

\section{Morus ruhra L.-Red mulberry}

Description: Deciduous trees with alternate, simple, toothed, palmately veined leaves, unlobed, mitten-shaped, or 3-lobed; flowers small, in cylindrical short racemes, the sexes separate; fruit a juicy short-cylindric cluster of small drupes, resembling a blackberry, turning from white to red to purple-black as it ripens.

Occurrence: Mulberry is a native tree of rich woods, along fence rows, and in waste places from Vermont to Michigan and south to Florida and Texas. The related M. alba L. (white mulberry) is a native of Asia and is cultivated and escaped throughout the area.

Poisoning: The unripe fruits and milky sap in leaves and stems cause hallucinations and stimulation to the nervous system with stomach upset.

To the physician: Gastric lavage or emesis; symptomatic.

\section{HEMP FAMILY - Camnabaceae}

Cannabis sativa L.-Marijuana, marihuana, hemp, hashish, pot (Figure 24)

Description: A coarse, rough-stemmed annual 6-12 ft. tall; leaves long-stalked, palmately divided into 3-7 leaflets which are narrow and coarsely toothed; leaves opposite below and alternate in the upper portion of the stem; flowers small and green, crowded on axillary branches.

Occurrence: A native of central and western Asia, marijuana is occasionally planted illegally in the United States, Hawaii, and Canada as a narcotic. It is also infrequently found in waste places and roadsides as a persistent weed in Canada southward to Georgia and Colorado.

Poisoning: The narcotic and toxic resins are found throughout the green or dried plants, although the parts are most 
dangerous during hot summer weather. The effects caused by drinking the extract, chewing the plant parts, or smoking "reefers" or the extracted resins have been known for more than two thousand years. Symptoms are exhilaration, hallucinations, delusions, blurred vision, poor co-ordination. stupor, and coma.

In comparison to other hallucinogenic drugs, marijuana is fairly mild and may be classed with the heavenly blue and pearly gates morning glory seeds or nutmeg. More potent is the mescaline from peyote (see pp. 56-57) and psilocybin and bufotenine from certain mushrooms. The most potent is the chemical LSD (lysergic acid diethylamide), the basic ingredient for which is lysergic acid from ergot, a cereal fungus. Nevertheless, marijuana is one of the most commonly used drugs both in Canada and in the United States. The real danger in marijuana is that persons who start using this narcotic often turn to stronger habit-forming drugs.

Federal and state laws prohibit the possession of living or dried parts of marijuana, both in the United States and in Canada.

To the physician: Gastric lavage or emesis: symptomatic and supportive.

Figure 24. Marijuana

(Cannabis sativa) An illegally planted narcotic.

From flora of West Virginia, courtesy of Dr. E. L. Core.

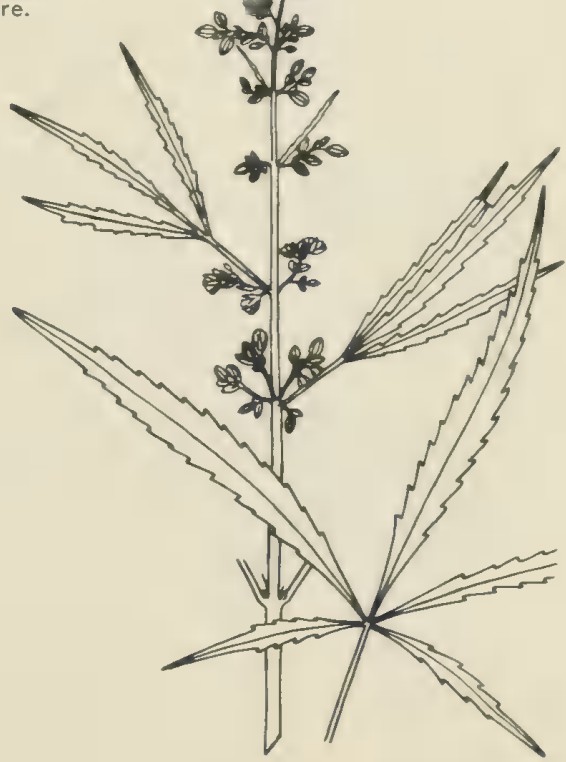




\section{Iagus spp. - Becech}

Beechnuts have caused poisoning in Europe, and although the American beech (Fagus grandifolia Ehrh.) is reported at edible, the nuts should not be eaten in quantity, particularly by children. Beech is one of the characteristic trees of the castern deciduous forest and common in rich woods and ravines, or cultivated as an ornamental. The European beech, F. sylratica $\mathrm{L}$.., is occasionally cultivated in northern United States as an ornamental.

Quercus spp.-Oak

Acorns and young shoots cause severe poisoning in livestock in certain areas. Although not reported as causing poisoning in humans, raw acorns may be dangerous if eaten in quantity. There are some sixty species in the United States and canada, forming the most common trees of many forest asseciations.

\section{MEZEREUM FAMILY - Thimelacicacie'}

Daphne mezereum L.-Daphne, spurge laurel

Description: Deciduous shrub $1-4 \mathrm{tt}$. tall; leaves simple, alternate, 2-3 in. long, hairless; flowers in clusters of 2-5 along branches of the previous year and appearing before the leaves, lilac-purple, fragrant, silky outside, $1 / 2$ in. or less long; fruit a round drupe $t_{+}$in. across, leathery and scarlet. Variety allor has white flowers and yellow drupes.

Occurrence: Daphne is cultivated as an ornamental shrub throughout the United States and has escaped in the Northeast and in eastern Canada. Other species are widely cultivated as ornamentals.

Poisoning: All parts, but primarily the very attractive drupes, contain a glycoside in which the aglycone is dihydroxycoumarin which causes burning or ulceration of the throat and stomach, vomiting, internal blecding with bloody 
diarrhea, weakness, coma, and death. Only a few drupes can be fatal to a child.

To the physician: Demulcents, gastric lavage or emesis; symptomatic and supportive.

\section{LECYTHIS FAMILY - Lecythidaceae}

This family of tropical trees is known mainly for the ornamental or edible nuts. Some are infrequently cultivated in southern Florida and Hawaii as ornamentals for their curious fruits (cannonball tree, monkey pots). Others are best known in North America through the importation of the edible and delicious Brazil nuts.

The nuts of some of the ornamental forms are said to cause nausea and chills if eaten in quantity.

\section{MYRTLE FAMILY-Mrraceae}

Rhodomyrtus tomentosa (Ait.) Hassk.-Hill gooseberry, downy myrtle

The downy myrtle is a small, hairy shrub to $5 \mathrm{ft}$. tall, a native of Asia, grown to a limited extent in southern California, Texas, and Florida. In Hawaii it is considered a noxious weed. The fruit is a rounded berry, dull pink with numerous small flat seeds embedded in soft pulp of rather sweet flavor. The fruits are occasionally eaten raw or made into pies or jam. It is not poisonous, but the danger lies in the possible incorrect identification of the related species below.

R. macrocarpa Benth. of Australia, called finger cherry or Queensland loquat, is poisonous. The fruits contain high quantities of saponin. causing temporary or permanent blindness if eaten. The danger from the finger cherry was considered so serious in 1915 that the Department of Education in Queensland, Australia, issued illustrations and descriptions of the plant to be displayed in all schools. In 1945 there were twenty-seven cases of permanent blindness reported among soldiers in New Guinea. This particular species is not cultivated in North America, to our knowledge. 


\section{HOLLY FAMILY - Aquifoliaceae}

Ilex spp.-Holly

There are a number of native and cultivated, deciduous and evergreen, holly shrubs and trees. Although they are not generally considered very poisonous, the red or black berries do cause disturbances such as vomiting, diarrhea, and stupor when eaten in quantity. They should be considered dangerous to small children.

One of the native species along the southeastern United States coast is called $I$. vomitoria, which indicates the potential action of the extract, long known and used (although questionably) as "black drinks" by the Indians. Early settlers in the Southeast enjoyed a harmless and very mild brew from the leaves called "yaupon tea."

To the physician: Gastric lavage or emesis; symptomatic.

\section{STAFF-TREE FAMILY - Celastraceae}

Euonymus spp. - Burning bush, strawberry bush, hearts-abustin', spindle tree, wahoo

Description: Shrubs or woody climbers with opposite, simple leaves; flowers small and greenish maroon; fruit conspicuous after splitting, with the seeds and capsule wall of contrasting shades of red, orange, or yellow.

Occurrence: There are a number of species of native shrubs of damp woods throughout the United States. Other species from Europe and Asia are cultivated extensively as ornamental shrubs or woody climbers. The related climbing bittersweet, Celastrus scandens L., is a vine or climbing shrub found in woods and thickets of damp soil from Ontario to Manitoba and south to North Carolina and New Mexico; it is also cultivated as an ornamental. The seeds may be poisonous to children if eaten in quantity.

Poisoning: The leaves, bark, and attractive seeds contain a poisonous principle which can cause vomiting, diarrhea, weakness, chills, coma, and convulsions. No cases have been reported from North America, but poisoning is known in Europe and all species should be suspected of potential danger.

To the physician: Gastric lavage or emesis; symptomatic.

\section{Internal Poisoning}




\section{BUCKTHORN FAMILY_Rhamnaceae}

Karwinskia humboldtiana Zucc.-Coyotillo

Description: Woody shrub or small tree with opposite, stalked leaves, 1-3 in. long with distinct straight lateral veins; flowers small, greenish, in lateral clusters; fruit a rounded drupe, turning brownish black when ripe, and about $1 / 2$ in. across.

Occurrence: This shrub is found on dry hills, in canyons, or in river valleys from southwestern Texas into Mexico and southern California.

Poisoning: The fruit and seeds have long been known by the Indians to cause paralysis a few days after eating. Children have been poisoned by eating these colorful fleshy fruits.

To the physician: Gastric lavage or emesis; symptomatic.

\section{Rhamnus spp.-Buckthorn}

Buckthorns are opposite-leafed shrubs which contain glycosides which are fairly strong laxatives. One species has the name $R$. cathartica, which indicates the potential action of the extract. Another, R. purshiana, is the source of cascara-a commonly used laxative.

Poisoning, by eating the black, juicy, berry-like fruit and the leaves, has been reported from Europe.

GRAPE FAMILY_-Vitaceae

Parthenocissus quinquefolia (L.) Planch.-Virginia creeper (Figure 25)

Description: A vine with alternate, long-stalked leaves which are palmately divided into 5 leaflets, each toothed on the margin, elliptical, and pointed; fruit a small blue berry, several in a cluster.

Occurrence: Virginia creeper is a well-known and very common vine of woods, fields and disturbed areas throughout the eastern United States and westward to Wyoming, Colorado, and Arizona (including the western $P$. vitacea Hitchc.).

Poisoning: This common plant is highly suspected of 


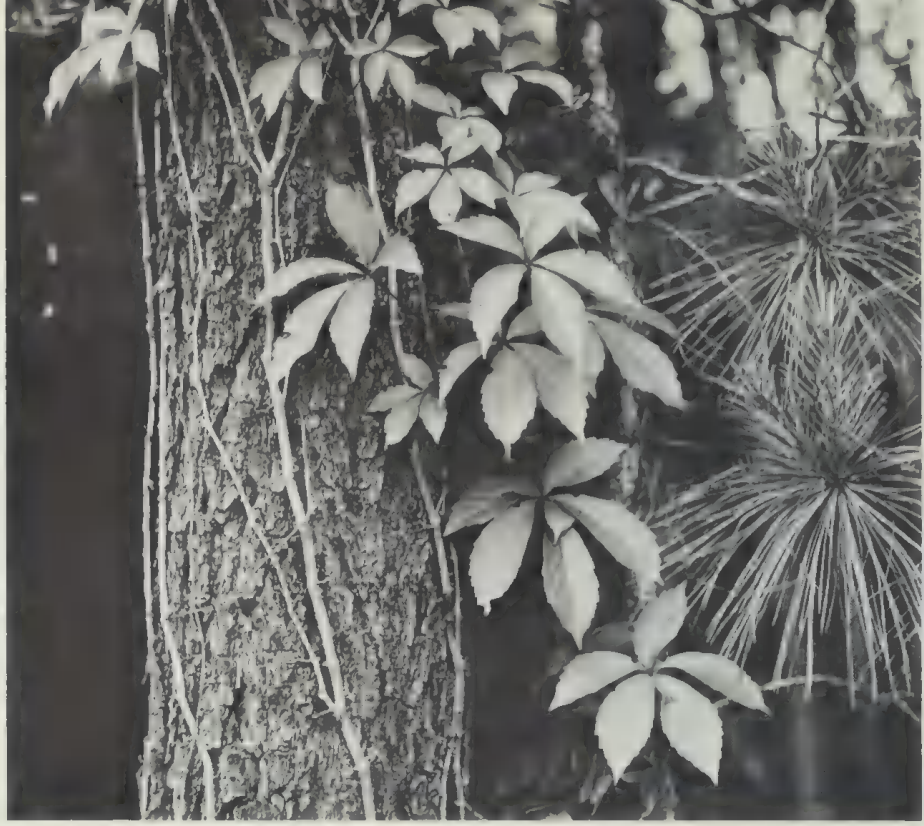

Figure 25. Virginia creeper (Parthenocissus quinquefolia) A common vine growing here on the trunk of a pine tree. Note five leaflets per leaf as compared with three in poison ivy. The berries are dangerous.

causing poisoning and death of children from eating the berries. The details are not known.

To the physician: Gastric lavage or emesis; symptomatic.

\section{MISTLETOE FAMILY-Loranthaceae or Viscaceae}

Phoradendron serotinum (Raf.) M. C. Johnston $[P$ flavescens (Pursh) Nutt.].- Mistletoe (Figure 26)

Description: Semiparasitic evergreen shrub with greenish branches; leaves opposite, simple, oblong, $1 / 2-11 / 2$ in. long, leathery; fruit a small white berry.

Occurrence: Mistletoe is a common parasite on the branches of various types of trees from New Jersey and southern Indiana southward to Florida and Texas. Additional species are found in western United States and southward. Mistletoe is the state flower of Oklahoma.

Poisoning: Gerarde's Herball (London, 1597) states that mistletoe "inwardly taken is mortall, and bringeth most greevous accidents, the toong is intlamed and swolne, the mind is distraughted, the strength of the hart and wits faile." The berries contain toxic amines which cause acute stomach 


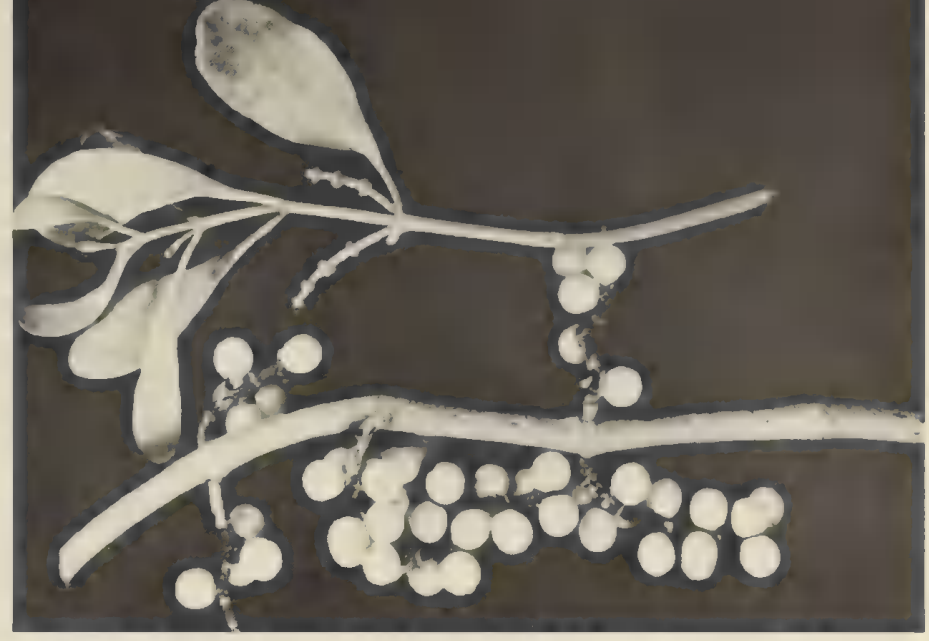

Figure 26. Mistletoe (Phoradendron serotınum) A frequent parasite in trees; the white berries used for Christmas decorations are poisonous. USDA Photograph.

and intestinal irritation with diarrhea and slow pulse. Since mistletoe is a favorite plant for Christmas decorations, care should be taken that the berries are kept out of reach of small children.

To the physician: Gastric lavage or emesis; supportive; potassium, procainamide, quinidine sulfate, disodium salt of edelate ( $\mathrm{Na}_{2} \mathrm{EDTA}$ ) have all been used effectively.

\section{MAHOGANY FAMILY-Meliacede}

Melia azedarach L.-Chinaberry, China tree, Chinaball tree (Figure 27)

Description: Deciduous tree $20-40 \mathrm{ft}$. tall; leaves alternate, 1-3 ft. long, twice pinnately divided with leaflets $1-2 \mathrm{in}$. long and toothed on the margins; flowers in large terminal panicles, lilac-colored and small; fruit a drupe. $1 / 2$ in. across, cream or yellowish and persisting throughout the winter.

Occurrence: A native of Asia, Chinaberry is frequently cultivated as an ornamental and has escaped freely and become naturalized in old fields and pastures, around farm buildings and homes, along borders of woods and fence rows. It is quite common in the southern United States and at lower altitudes in Hawaii.

Poisoning: The fruits, as well as "tea" made from the 


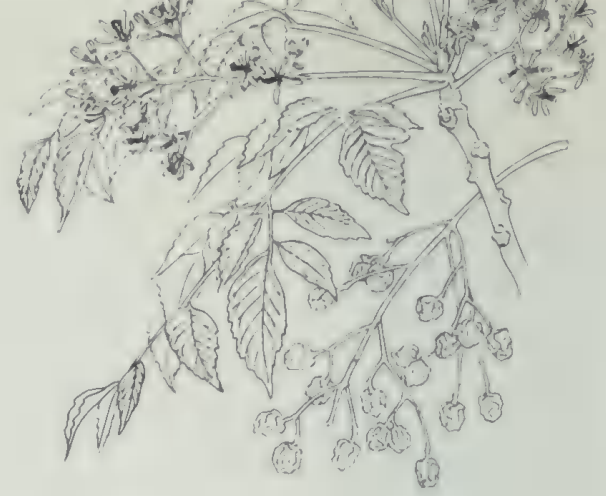

Figure 27. Chinaberry (Melia azedarach) A tree with large divided leaves, small lilac flowers, and yeliowish wrinkled berries. Courtesy of the Florido Agricultural Experiment Station.

leaves, are poisonous to children if eaten in quantity. The toxic principle is probably a resinoid which causes narcotic effects, vomiting and diarrhea, paralysis, irregular breathing, and very marked symptoms of suffocation. Six to 8 fruits caused death in a young child.

To the physician: Gastric lavage or emesis; symptomatic.

\section{SOAPBERRY FAMILY-Sapindaceae}

\section{Blighia sapida Koenig-Akee}

This stiff-branched tree with pinnately divided leaves is native in western Africa. It was named for Captain W. Bligh, commander of the "Bounty." Akee is grown in the tropics, including southern Florida, for its edible fruit, which is a capsule with thick hard walls, roundish or triangular in outline, about 3 in. across, and straw-colored to red. Each of the 3 cells of the capsule contains I round shining black seed with a white oily base (aril). The white aril of the mature fruit is prepared and eaten without harm.

Poisoning: Acute vomiting followed by convulsions, coma, and death occurs when one eats the fruit wall, the black seeds, the white aril of unripe fruit, or the rancid spoiled aril.

To the physician: Gastric lavage or emesis; symptomatic and supportive; intravenous administration of glucose is important because of severe hypoglycemia produced by peptides. 


\section{BUCKEYE FAMILY - Hippocastanaceae}

Aesculus spp.-Buckeye, horsechestnut

Description: Trees and shrubs; leaves deciduous, opposite, palmately divided with 5-9 leaflets on a long stalk; leaflets widest at the middle or above and toothed on the margins; flowers yellow, red, or white, 4-5-parted, in terminal panicles appearing with the leaves; fruit a 3-valved capsule with a thick leathery husk enclosing $1-6$ brown shiny seeds with a large pale scar.

A. californica (Spach) Nutt.-California buckeye

Flowers white, stamens longer than the 5 equal petals; fruit rough. This is a shrub or small tree of dry hillsides and canyons in the Pacific Coast Range and the Sierras. The related $A$. parryi Gray is found in northern Baja California, Mexico.

A. glabra Willd-Ohio buckeye

Flowers yellow, stamens longer than the 4 petals; fruit spiny. This tree is found in woods and along streams in western Pennsylvania to southern Michigan and Nebraska south to Arkansas and Texas.

A. hippocastanum L.-Horsechestnut

Flowers white, in broad panicles; fruit spiny. This very beautiful tree is cultivated in the United States and Canada. There are a number of horticultural forms and hybrids. It is a native of southeastern Europe, and a favorite ornamental in Europe and England.

A. octandra Marsh.-Yellow buckeye

Flowers yellow with flower stalks glandular hairy, stamens shorter than the petals; fruit smooth. Yellow buckeye is a large tree of the Ohio River valley and in the Appalachians southward to northern Alabama and Georgia. It is one of the characteristic trees of rich woods of the southern Appalachians.

A. parviflora Walt.-Bottlebrush buckeye

Flowers white, stamens very long, inflorescence a long 
narrow panicle; fruit smooth. This is an uncommon shrub native in the Coastal Plain of southern Georgia and Alabama, but it has been cultivated occasionally northward.

A. Paria L.-Red buckeye, fïrecracker plant

Flowers typically red, except for a yellow form in Texas; fruit smooth. This beautiful shrub is found in low woods of the Coastal Plain from North Carolina to Florida and west to Texas.

A. sylvatica Bartr.-Painted buckeye (Figure 28)

Flowers yellow, the flower stalks not glandular; fruit smooth. Painted buckeye is a shrub of moist woods in the Piedmont from southern Virginia to Alabama and southeastern Tennessee.

Poisoning: The leaves, flowers, young sprouts, and entire seeds contain the glycoside esculin. Children have been poisoned by eating the seeds, or making "tea" from the leaves and twigs. Symptoms are nervous twitching of muscles, weakness, lack of co-ordination, dilated pupils, vomiting, diarrhea, depression, paralysis, and stupor. Amounts as little as 1 per cent of the child's weight may be poisonous. Roots, branches, and fruits have been used to stupify fish in ponds. Honey, mainly from the California buckeye, is also poisonous.

To the physician: Gastric lavage or emesis; symptomatic.

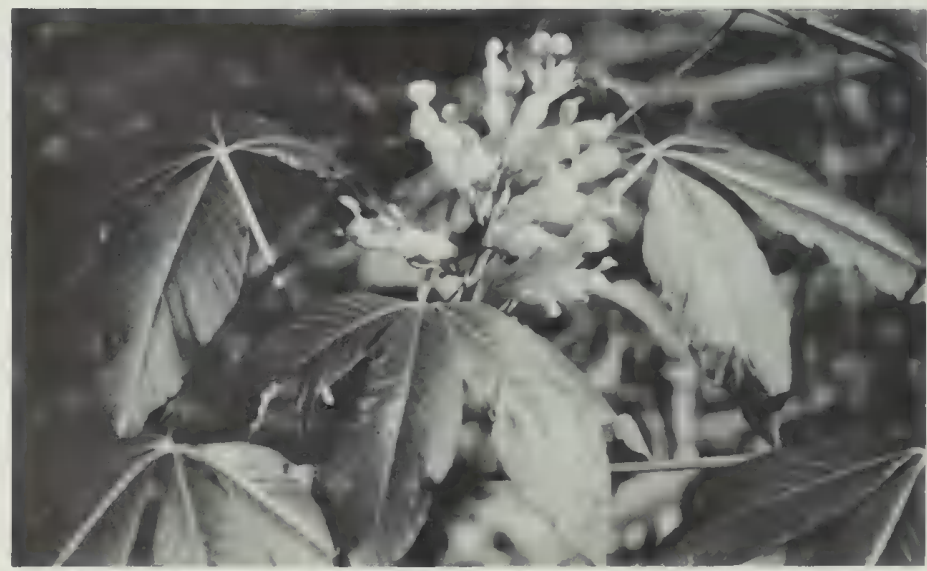



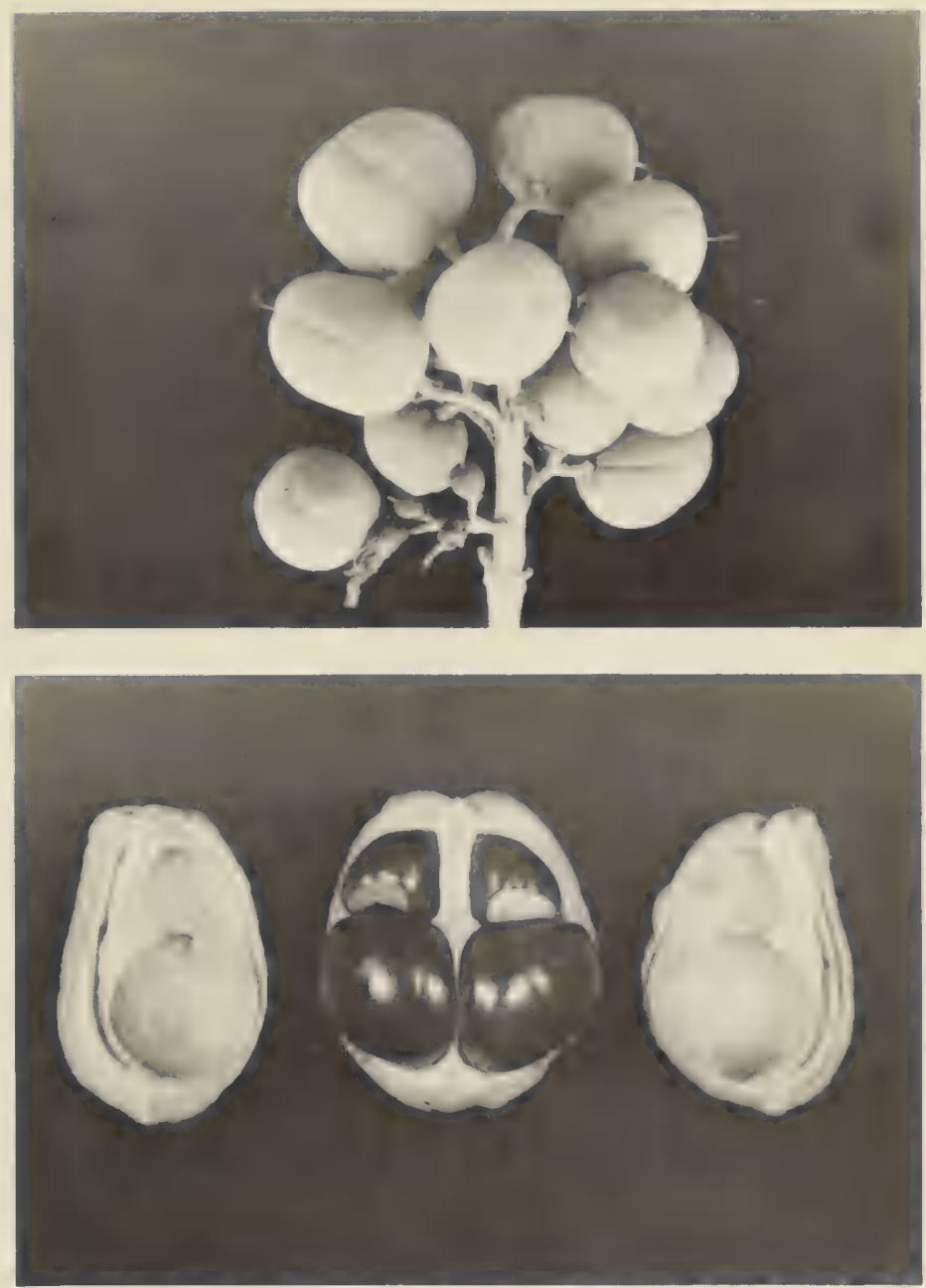

Figure 28. Painted buckeye (Aesculus sylvatica) Shrub with five leaflets, yellow flowers, and poisonous brown seeds in leathery husks.

Enthroxylon coca Lam.--Coca

Coca is an evergreen shrub or tree with alternate, simple leaves, small flowers which vary from yellow to white, and red to brownish drupes. It is a native in South America and is extensively cultivated in South America, Ceylon, India, and Java. Coca is occasionally cultivated in southern Florida, 
California, and Hawaii and could be of danger if the leaves are eaten in quantity by children.

Coca has a long and fascinating history, known back to pre-Incan graves of the sixth century. It was known as the "divine plant" of the Incas during the tenth century in Peru. Chewing of coca leaves increases energy, decreases hunger, and dulls pain and generally enables the user to work harder and with less food than he could otherwise. The Spanish, who conquered Peru in the early sixteenth century, took advantage of these properties and encouraged coca chewing among the Indians so that they could endure the slavelike work in the silver and gold mines.

Today coca claims more addicts than any other narcotic fifteen million in South America, mostly in Peru. The coca addict chews the leaves two to three times a day, particularly before work, along with lime or alkaline ashes of certain plants which aid in the extraction of the narcotic alkaloids. This drug has, through many generations, been of primary importance in the psychological disturbances and general racial degeneration in the Andean region and is of major social and political concern today in those regions.

In addition to numerous aromatic and sweet alkaloids, coca leaves contain cocaine, used extensively as a local anesthetic since the late nineteenth century. Now, synthetic substitutes have generally replaced its use by the physician. Cocaine, however, is a potent and dangerous habit-forming alkaloid. The "dope fiend" of the novelist is a cocaine addict.

Coca leaves are also important in the soft-drink industry. In 1887, A. G. Candler of Atlanta, Georgia, obtained a formula from Brazil for medical purposes, and the drink, made from a combination of coca leaves and the cola nut (a plant of the chocolate family), was obtainable by prescription only from his wholesale drug business. As the stimulating properties of the coca-cola drink became known, it gradually developed into the prosperous business of today. The cocacola syrup contains caffeine from the cola nut plus the fatty acids from the coca leaves after the alkaloids have been removed. The drink is therefore quite lacking in the narcotic effects received from chewing the coca leaves. 
Poisoning: Cocaine produces various symptoms depending on the individual. Some people are affected by very small amounts with headache, rapid respiration, delirium, coma, or convulsions with wide dilation of pupils. Persons addicted to cocaine eventually develop digestive disturbances, muscular twitching, insomnia, mental, moral, and physical deterioration, often resulting in death.

To the physician: Gastric lavage or emesis; symptomatic, activated charcoal.

\section{CALTROP FAMILY - Zygophyllaceae}

Guaiacum officinale L.-Lignum vitae

This small evergreen tree of the American tropics yields the valuable lignum vitae, an extremely hard and heavy wood, and also the resin guaiacum used for medicines, stains, and as a chemical indicator. The resin in the wood and fruit is poisonous if eaten in quantity. The tree is occasionally planted in southern Florida, Mexico, southern California, and Hawaii as an ornamental.

\section{GINSENG FAMILY - Araliaceae}

Hedera helix L.-English ivy, ivy

Description: Woody, climbing, or creeping vine with numerous short aerial roots; leaves evergreen, leathery, alternate, and simple, stalked, the blade palmately veined and variously shaped in different horticultural varieties; flowers small and greenish; fruit a small, 3-5-seeded black berry in clusters $4-10$.

Occurrence: A native of Europe, ivy is very frequently planted as an ornamental vine. It occasionally escapes or persists in various habitats throughout most of the United States, Hawaii, and southern Canada.

Poisoning: The leaves and berries contain the saponic glycoside hederagenin. Symptoms are excitement, difficult breathing, and coma. The related Aralia spinosa L., Hercules' club or devil's walkingstick, of the eastern United States has black berries that may also be poisonous if eaten in quantity. 
To the physician: Gastric lavage or emesis; symptomatic and supportive, paraldehyde $(2-10 \mathrm{cc}$.) IM, oxygen and artificial respiration as necessary.

CARROT FAMILY-Apiaceae, Umbelliferae

Cicuta maculata L.-Water hemlock, spotted water hemlock, spotted cowbane (Figure 29)

Description: Perennial herbs 3-7 ft. tall with clustered, short and thickened tuberous roots and hairless, purplestriped or -mottled stems which are hollow except for

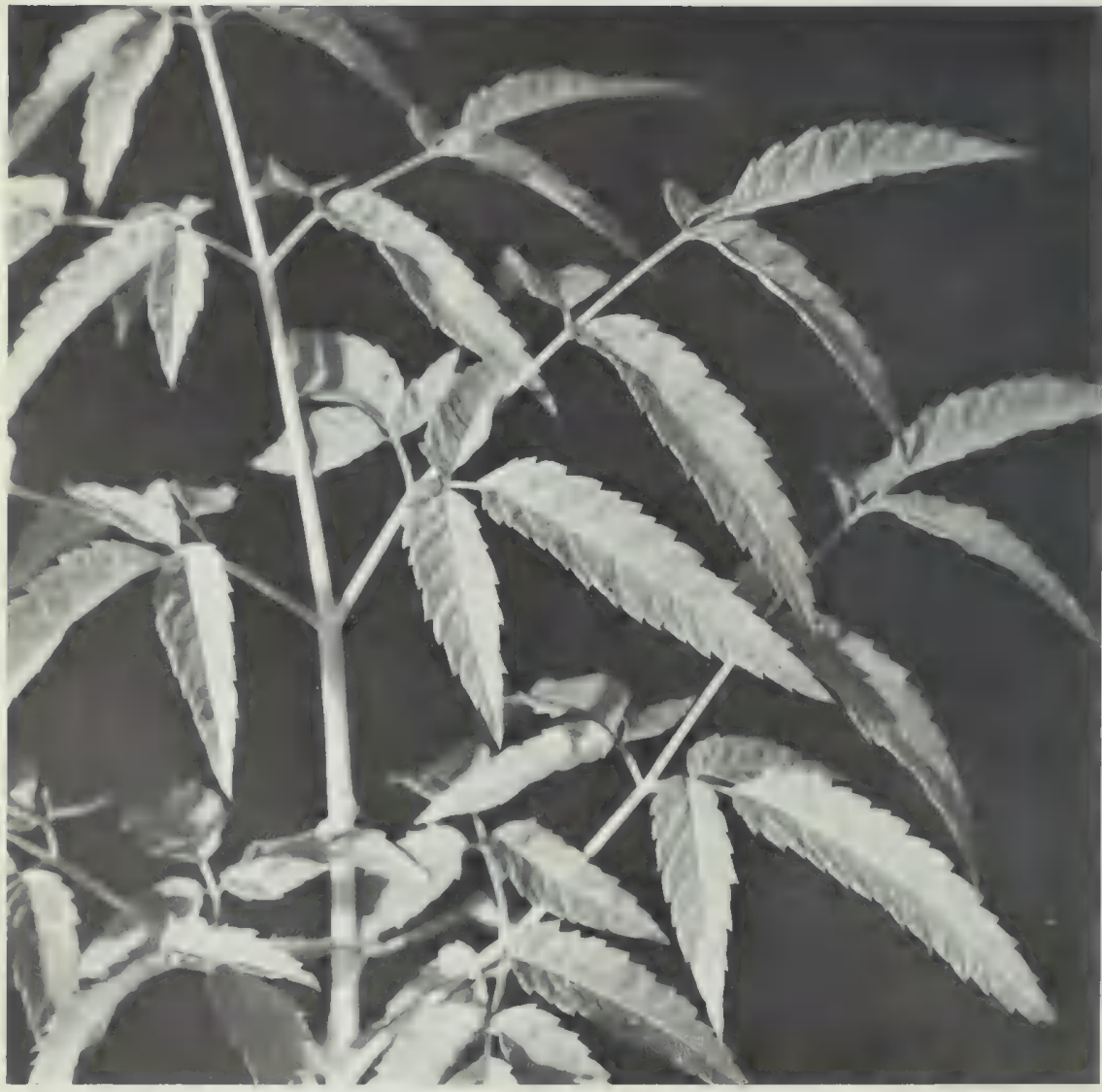

Figure 29. Water hemlock (Cicuta maculata) A common herb with very large divided leaves, flot-topped clusters of small white flowers, and a cluster of tuberlike roots; note cavities at base of the stem. Drawing of root a USDA Photograph. 
Poisoning: The poisonous chemicals are found mostly in the rootstock and much less in the aboveground parts of the plant. The root is extremely poisonous, and one mouthful of root is sufficient to kill a grown man. It is so often mistaken for wild parsnip or wild artichoke that deaths are frequent. Children have been poisoned by making peashooters and whistles from the hollow stems. Symptoms are diarrhea, violent convulsions and spasms, tremors, extreme stomach pain, dilated pupils, frothing at mouth, delirium, and death.

To the physician: Gastric lavage or emesis; symptomatic; control convulsions with parenteral short-acting barbiturates.

Conium maculatum L.-Poison hemlock, poison fool's parsley (Figure 30)

Description: A biennial herb with a hairless purplespotted or -lined hollow stem to $8 \mathrm{ft}$. tall by the second

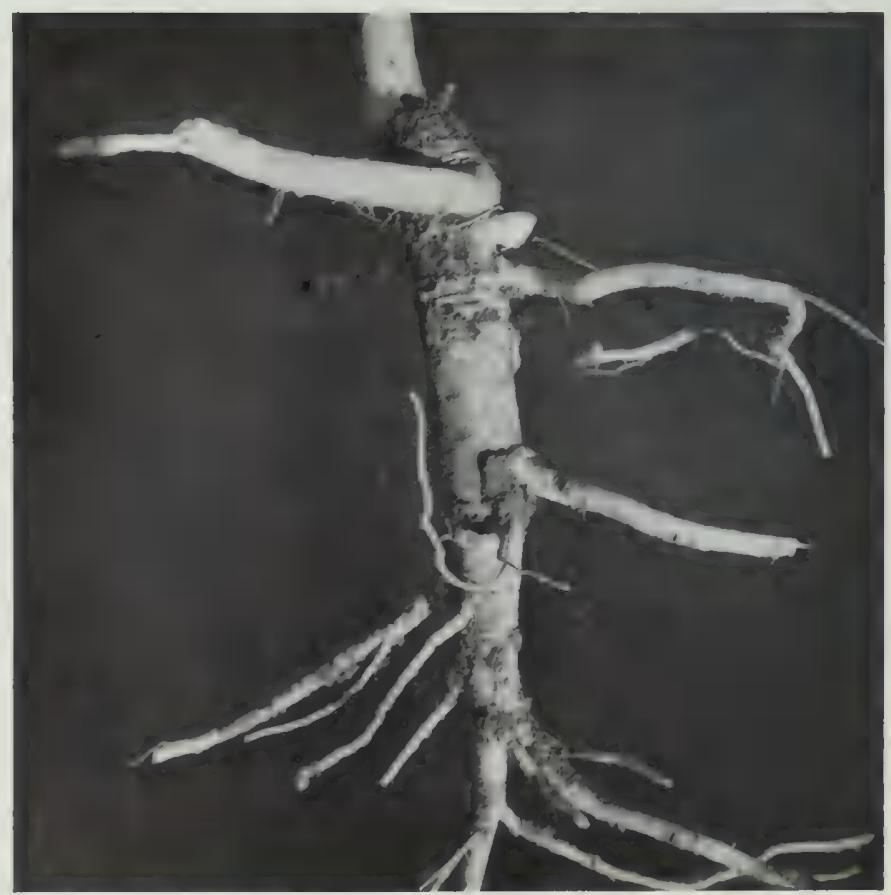

Figure 30. Poison hemlock (Conium maculatum) A European herb of historical fame and a weed in the U.S. The leaves are very deeply divided into minute leaflets (USDA Photograph). The root is a single taproot. (See facing page.) 
season; taproot long, solid, and turnip-like; leaves large, 3-4 times pinnately divided, alternate and with a clasping stalk; the leaflets very minute; flowers and fruit similar to those in Cicuta.

Occurrence: A native of Eurasia, poison hemlock is found occasionally as a weed in waste places, marshy areas, and

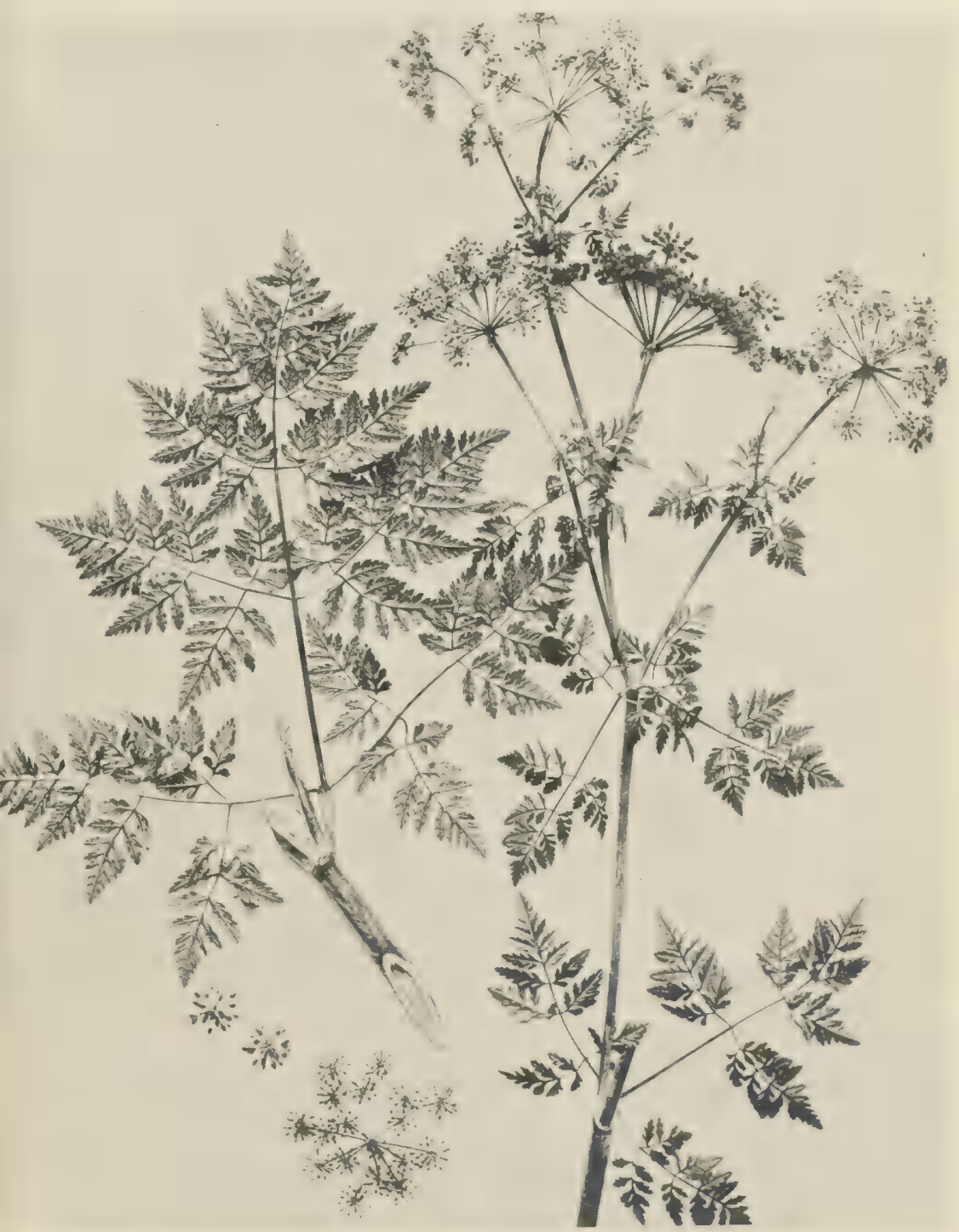


roadside ditches throughout eastern United States, the Rocky Mountains, Pacific coast, and southern Canada.

Poisoning: This is one of the most noted of the poisonous plants since it was used by the early Greeks as a regal means of dying. The offenders would crown themselves with a garland of flowers; then, with a brave smile and appropriate final remarks to those gathered, they would gulp the cup of hemlock. So went Socrates and others. It is not such a regal death in the United States, where, quite by accident or ignorance, the leaves are sometimes mistaken for parsley or the seeds are mistaken for anise. The taste is quite unpleasant, however, and toxic quantities are seldom consumed. Symptoms are vomiting and diarrhea, muscular weakness, nervousness, trembling, dilation of pupils, weak pulse, convulsions, coma, and death. The poisonous principles are coniine and other alkaloids; they occur in greatest concentration in the seeds and root.

To the physician: Gastric lavage or emesis; saline cathartic; keep airway clear, oxygen and artificial respiration; anticonvulsive therapy.

Note: The two hemlocks just mentioned (Cicuta and Conium) should not be confused with the trees called hemlock, which are conifers of the genus Tsuga and not at all poisonous.

\section{MUSTARD FAMILY-Brassicaceae, Cruciferae}

Various members of the mustard family, both wild and cultivated throughout the area, can cause vomiting and diarrhea if eaten raw and in quantity by small children. The roots are the most dangerous. Cabbage, mustard, kale, brussels sprouts, cauliflower, broccoli, rutabaga, turnip, radish, cress, horseradish, and stock are examples.

\section{GOURD FAMILY - Cucurbitaceae}

Momordica charantia L.-Wild balsam apple, balsam pear, bitter gourd

Description: Climbing or creeping vine; leaves alternate, deeply palmately lobed, to $2 \frac{1}{2}$ in. across; flowers yellow, 
tubular, small; fruit warty, orange-yellow, $11 / 2-5$ in. long, oblong, and tapered at both ends, the seeds and pulp red.

Occurrence: This little vine is found on the Coastal Plain from Florida to Texas in sandy soils and waste grounds. It is cultivated in gardens in Hawaii.

Poisoning: The seeds and wall of the fruit contain a purgative causing vomiting and diarrhea. One fruit is sufficient to cause severe stomach and intestinal disorders in a child. The red fleshy covering around the seed (aril) is harmless and is sucked from the seeds by children and adults alike.

To the physician: Gastric lavage or emesis; symptomatic.

SPURGE FAMILY - Euphorbiaceae

Aleurites fordii Hemsl._-Tung oil tree, tung nut (Figure 31 )

Description: Deciduous tree to $25 \mathrm{ft}$. tall; leaves alternate, simple, long-stalked, heart-shaped, to $10 \mathrm{in.} \mathrm{long,} \mathrm{margins}$

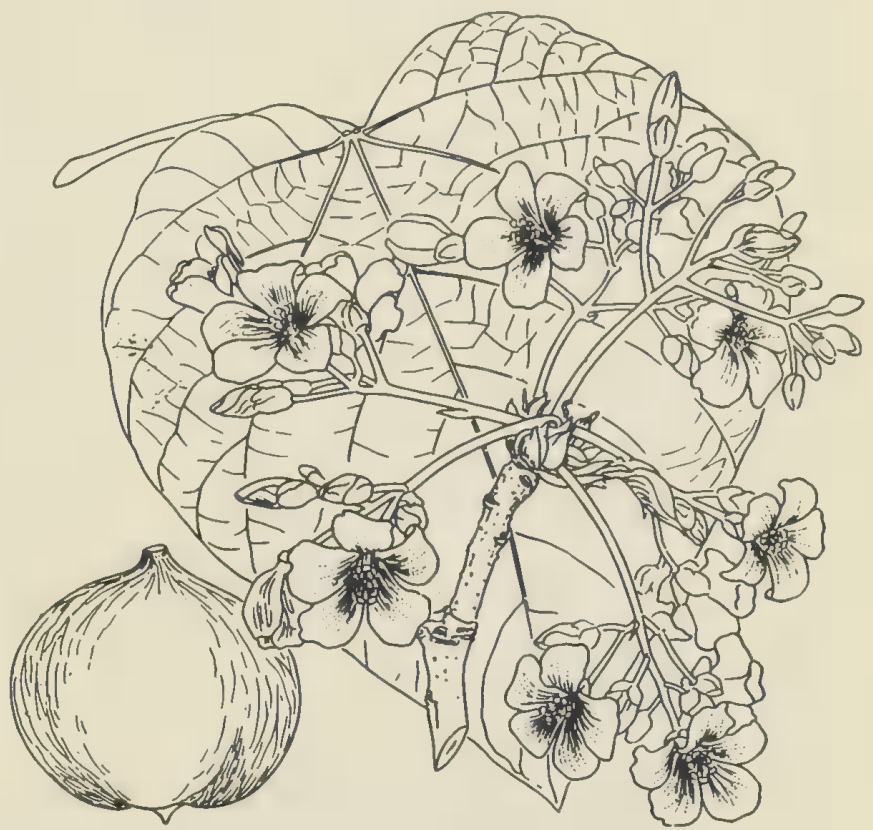

Figure 31. Tung nut (Aleurites fordii) Tree commercially planted for tung oil. The attractive seeds are extremely dangerous. Courtesy of the Florida Agricultural Experiment Station. 
smooth; flowers pale pink to white, petals $5-7$, in large panicles; fruits on drooping stalks, $2-3$ in. across, globular, turning brown at maturity, seeds $3-7$ with rough seed coats.

Occurrence: Tung oil tree is a native of China and is planted in the Gulf Coast region from northern Florida to Texas. Large commercial orchards are planted for the tung oil. Trees are also planted in the same area as ornamentals and for shade. Related species are less toxic. The candlenut ( $A$. moluccana Willd.) has edible seeds which are roasted and eaten in Hawaii, but raw seeds are poisonous.

Poisoning: All parts of the tung oil tree contain a saponin and phytotoxin. Symptoms from eating the attractive seeds are very severe stomach pain with vomiting, diarrhea, weakness, slowed breathing, and poor reflexes. Death may occur. A single seed can cause severe poisoning, and cases are frequent where the trees are common.

To the physician: Gastric lavage or emesis; symptomatic; control convulsions with parenteral short-acting barbiturates.

\section{Euphorbia spp.-Spurge}

Description: Numerous species of upright or prostrate herbs or shrubs, sometimes cactus-like; juice milky and acrid; leaves alternate or opposite, simple, smooth or toothed; "flowers" (cup-shaped structures bearing minute male and female flowers inside) greenish and often bearing glands or white petal-like appendages on the rim of the cup; fruit a globose, 3-lobed capsule on a long stalk extending from the cup.

E. corollata L.-Flowering spurge

Slender, diffusely branched herb; leaves $1-2$ in. long, green, and smooth margined; white petal-like appendages of the "flower" conspicuous. This is a common native weed of fields, woods, and disturbed areas throughout eastern United States.

E. cyparissias L.-Cypress spurge

Glabrous perenrial with erect stems to $1 \mathrm{ft}$. tall; leaves crowded above, narrowly linear, $1 / 2-1$ in. long. A native of Eurasia, this popular border plant is cultivated in gardens 
or yards and occasionally escapes in various parts of the United States.

E. lathyris L.-Caper spurge, mole plant, sassy jack

Glabrous annual to $3 \mathrm{ft}$. tall; leaves mainly opposite, $11 / 2-5$ in. long; capsule about $1 / 2$ in. across. This is a native of Europe which is occasionally cultivated and sometimes escapes as a weed in various areas throughout the United States.

E. marginata Pursh-Snow-on-the-mountain

Annual herb to $2 \mathrm{ft}$. tall; leaves $1-3$ in. long, toothless, the upper leaves conspicuously bordered with white; "flower" with conspicuous white petal-like appendages. Widely cultivated in gardens and lawns as border plants, it is a native of dry plains and valleys from Montana to Mexico and sometimes escapes in eastern United States. The use of a decoction of this plant in an effort to cause abortion resulted in the death of a young woman.

E. milii Ch. des Moulins (E. splendens Hook.)-Crownof-thorns (Figure 32)

A woody, branched, very spiny, shrublike plant to $4 \mathrm{ft}$. tall; leaves few and scattered mostly on the new growth, $1-21 / 2$

Figure 32. Crown-of-thorns (Euphorbia milii) A shrubby, spiny, ornamental plant with milky juice. 
in. long, not toothed; "flowers" located above 2 broad red bracts each about $1 / 2$ in. across. This attractive shrub is cultivated as a house or patio plant, or very commonly grown outside in southern United States and Hawaii.

\section{E. pulcherrima Willd--Poinsettia}

A shrub with large alternate leaves, blades 3-6 in. long, not toothed or with a few large teeth; "flowers" clustered at the top with red, pink, or cream leaves just below and forming the showy parts of the plant. This is a popular winter-flowering shrub used extensively at Christmas as an indoor ornamental, and planted outside in southern United States and Hawaii as a shrub or hedge.

E. tirucallii L.-Milk bush, Indian tree spurge, pencil tree, Malabar tree, monkey fiddle (Figure 33)

A succulent, spineless, shrublike plant, the branches green and cylindric, about $1 / 4-1 / 2$ in. thick; leaves linear, small, and only a few limited to the tips of the branches and soon dropping. This rather odd-looking plant is cultivated as a potted plant for the house and patio.

Poisoning: The spurges contain a toxic principle in the milky sap which can cause dermatitis in some people and severe poisoning if eaten in quantity. There are records of death caused by caper spurge and snow-on-the-mountain and severe irritation to the mouth, throat, and stomach by other species. These various spurges are of particular importance since many are very common in lawns or in the home.

To the physician: Gastric lavage or emesis; symptomatic.

Note: It is hearsay that all plants with milky juice are poisonous, for there are a number of harmless and even very edible plants such as lettuce, dandelion, or mulberry with this characteristic. Nevertheless, since many poisonous plants, such as milky-cap mushroom, spurge, dogbane, and milkweed do have milky juice, it should be considered a signal for caution.

Hippomane mancinella L.-Manchineel

The fruit of the manchineel is extremely poisonous if 


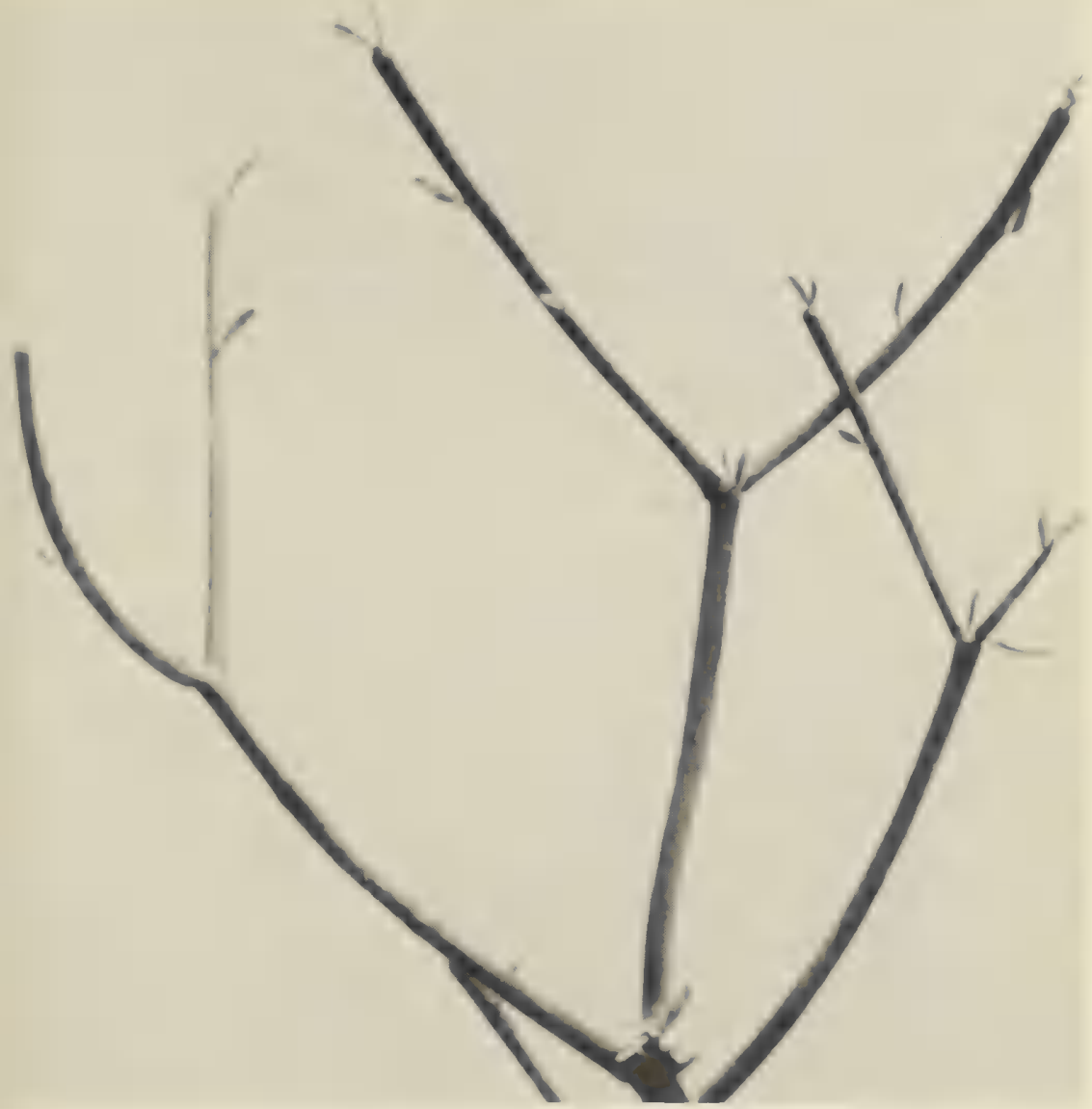

Figure 33. Milk bush or pencil tree (Euphorbia firucallii) An unusual succulent ornamental with milky juice.

eaten, causing stomach pain, vomiting, and bloody diarrhea. See p. 17 for a description of the tree.

To the physician: Gastric lavage or emesis; mineral oil.

Hura crepitans L.-Sandbox tree, monkey dinner bell

This large spiny tree from the American tropics is occasionally planted as an ornamental in southern United States and Hawaii for the curious explosive fruits. The capsules, when ripe, spring open with explosive violence and loud noise and throw the seeds many feet. The milky 
juice causes severe vomiting and diarrhea when eaten. Two or 3 seeds are sufficient to cause severe symptoms. The bark is used to kill fish in some tropical areas.

To the physician: Gastric lavage or emesis; symptomatic. Jatropha spp.

Description: Trees and shrubs; leaves alternate, stalked, palmately veined, and 3-5 lobed or deeply cut into 9-11 segments; flowers red or yellow, small; fruit a capsule.

J. curcas L.-Purge nut, curcas bean, physic nut, Barbados nut (Figure 34)

This species is widely cultivated in Florida and Hawaii as an ornamental.

J. gossypifolia L.-Bellyache bush

This is a shrub cultivated as an ornamental in southern Florida and Hawaii.

J. integerrima Jacq.-Peregrina

This species is cultivated as an ornamental in southern Florida.

J. multifida L.-Physic nut, coral plant

Physic nut is a native of tropical regions and is frequently planted from southern Florida to Texas and in Hawaii.

Poisoning: Sap from all parts of the plants contains curcin, a toxalbumin. The attractive fruits or seeds, not infrequently eaten by children, cause nausea, violent vomiting, bloody diarrhea, and coma from a few minutes to several hours after eating. Three seeds are possibly sufficient to cause severe symptoms. It is considered one of the chief causes of poisoning in south Florida.

To the physician: Gastric lavage or emesis; symptomatic; treat for shock.

Manihot esculenta Crantz-Cassava, manioc, tapioca

Cassava, a bushy herb or shrub and native of Brazil, is widely cultivated throughout the tropics for the tuberous edible roots which are used as a starchy food. The underground tubers, similar to sweet potatoes, are boiled and 
eaten or fixed in various ways such as in the formation of tapioca. There is no real danger as normally used.

The raw root, or peelings of the tubers, however, can form high concentrations of prussic acid sufficient to cause death from cyanide poisoning. The greatest danger lies in the areas of southern United States where the plants are occasionally cultivated and the roots are available to children or to those adults unfamiliar with the correct process of fixing the roots.

To the physician: Immediate gastric lavage or emesis: treat for cyanide poisoning.

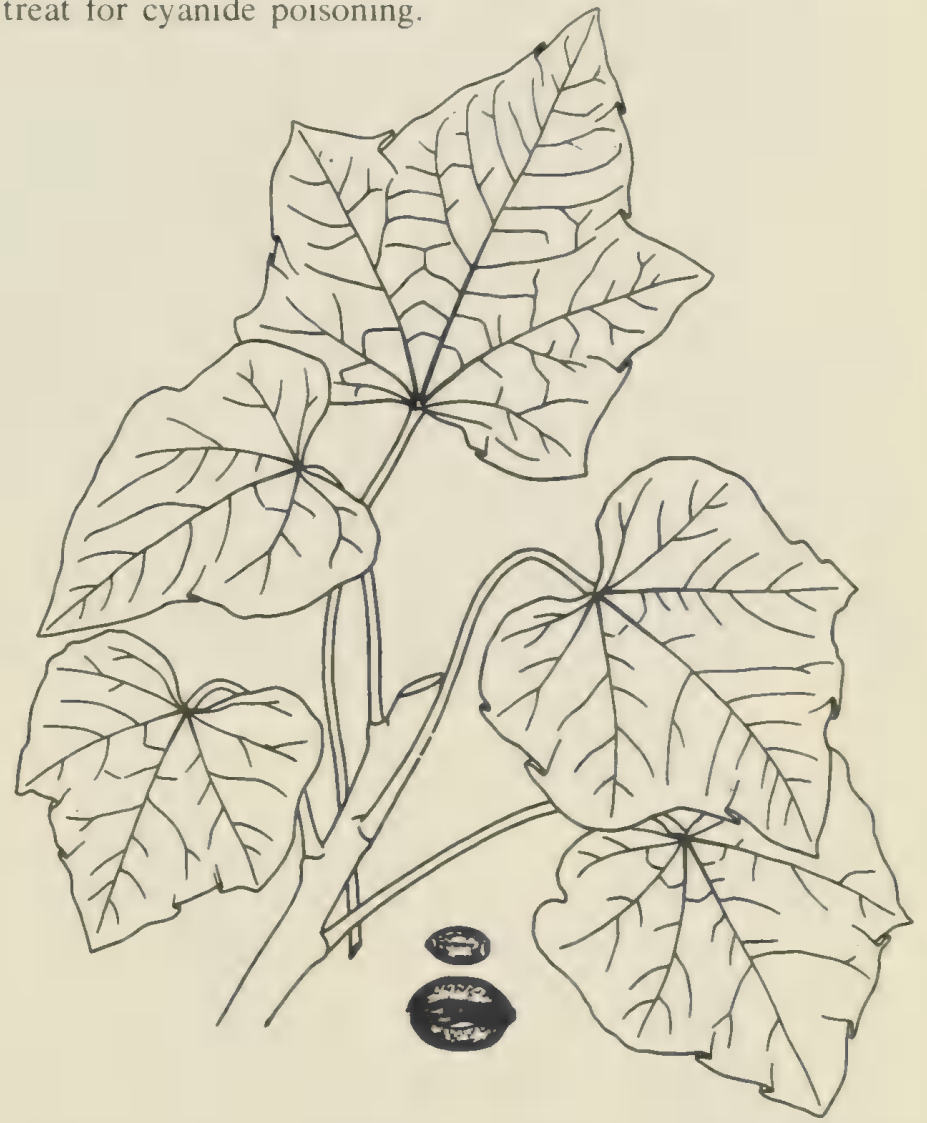

Figure 34. Purge nut or Barbados nut (Jatropha curcas) An ornamental of tropical regions with poisonous seeds. Courtesy of the Florida Agricultural Experiment Station. 


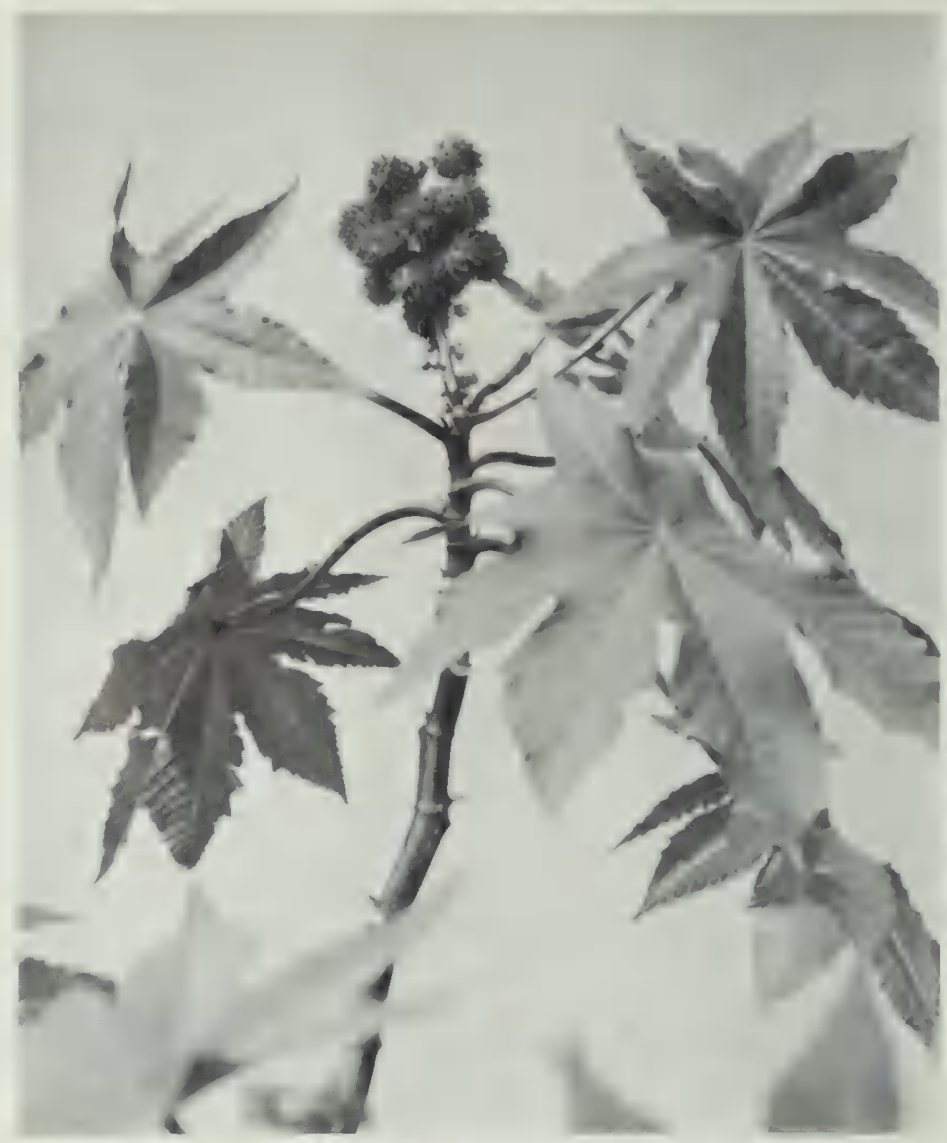

Figure 35. Castor bean (Ricinus communis) An attractive ornamental and commercial plant with very dangerous seeds. (See facing page.) Close-up of seeds a USDA Photograph.

Ricinus communis L.-Castor bean, castor-oil plant (Figure 35)

Description: Shrublike herb, stems 4-12 ft. tall, branched, green to reddish or purple; leaves alternate, simple, longstalked, to $30 \mathrm{in}$. wide and palmately lobed with 5-11 long lobes which are toothed on the margins, green or reddish; fruits oval, green or red, and covered with fleshy spines; seeds 3 per capsule, about $1 / 2-3 / 4$ in. across, elliptical, glossy, black or white or usually mottled with gray, black, brown, and white. 


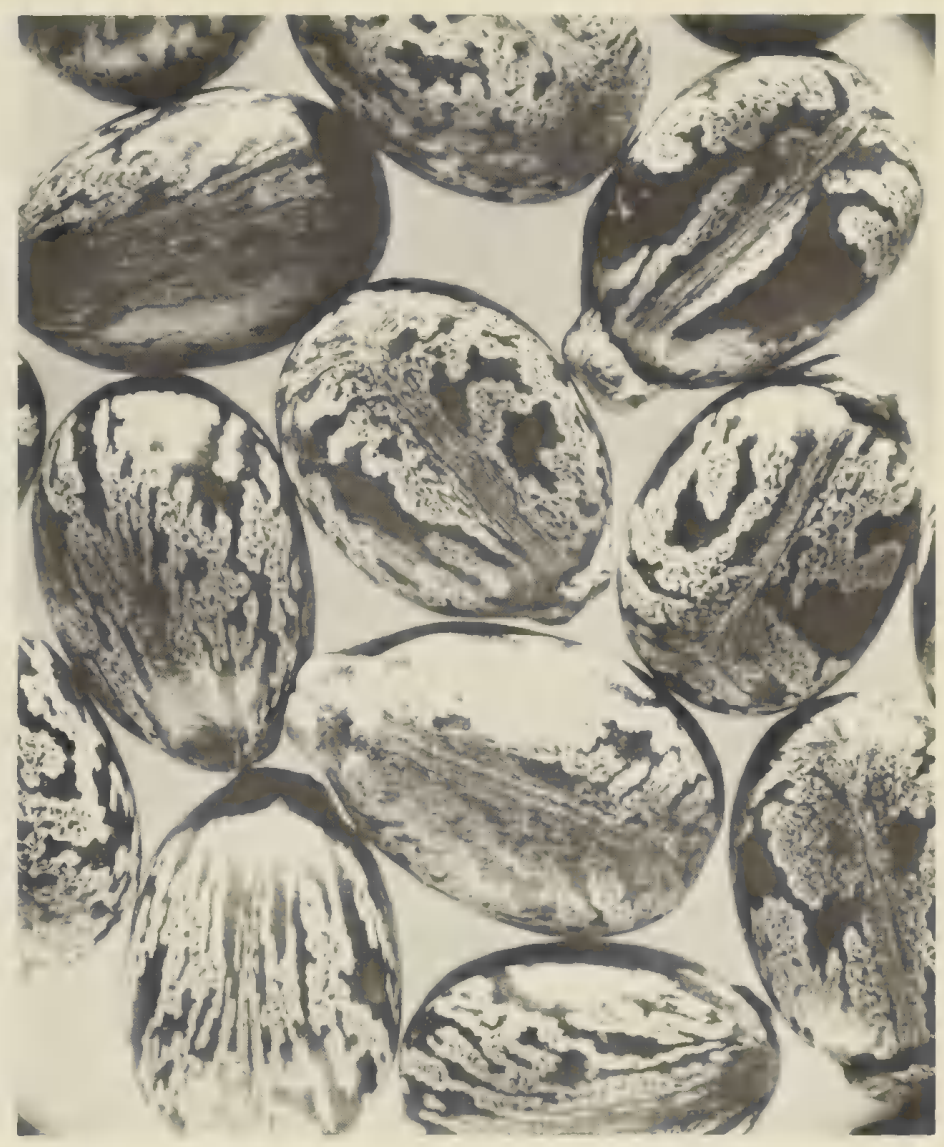

Occurrence: Castor bean is cultivated as an ornamental in yards, and occasionally escapes, mostly in the southern United States and lower altitudes in Hawaii. It is grown commercially in California and southern states for the oil extracted from the seeds.

Poisoning: The seeds, if chewed, are most toxic; leaves are less toxic. Ricin, a phytotoxin, causes burning of the mouth and throat, nausea, vomiting, severe stomach pains, diarrhea, excessive thirst, prostration, dullness of vision, convulsions, uremia, and death. One to 3 seeds can be fatal to a child; 2 to 4 seeds may cause very severe poisoning or fatality in an adult, and 8 are generally fatal to an adult. 
Death from uremia may occur up to 12 days after eating. If seeds are swallowed without chewing, poisoning is unlikely because of the hard seed coat.

This is a commonly cultivated plant, and the seeds are readily available for children to play with or for making necklaces. The danger may be eliminated if the flower stalks or seed heads are removed before the fruits are mature. If this is done regularly, castor bean can be a beautiful, and safe, ornamental plant for the yard. Otherwise it is one of the chief causes of poisoning among children.

The seeds are used for the extraction of castor oil, used as a medicinal drug, an ingredient in soaps, and as a lubricant.

To the physician: Immediate gastric lavage or emesis; supportive; keep urine alkaline with 5-15 gm. sodium bicarbonate daily.

\section{HEATH FAMILY_Ericaceae}

Kalmia latifolia L.-Mountain laurel, mountain ivy, ivy bush (Figure 36)

Description: Large evergreen shrubs to $35 \mathrm{ft}$. tall; leaves nearly all alternate, $1 \frac{1}{2}-41 / 2$ in. long, margin not toothed, bright green below and dark green above; flowers in terminal clusters, white to rose, anthers held in small pockets in the side of the corolla tube until pollination; fruit a dry capsule.

Occurrence: Mountain laurel is found in moist woods and along streams, on mountain tops and in heath balds (laurel slicks) of eastern Canada southward in the Appalachian Mountains and Piedmont and infrequently in the eastern Coastal Plain. This is one of the most beautiful flowering shrubs of the Appalachians. It is the state flower of Connecticut and Pennsylvania.

The related $K$. angustifolia $\mathrm{L}$. and $K$. polifolia Wang., lambkill, sheep laurel, wicky, swamp laurel, are small shrubs with opposite or whorled leaves and narrow inflorescences of small flowers. They occur in wet meadows, bogs, and pocosins from Alaska to California and Colorado and northeastward to eastern Canada and southward in the 


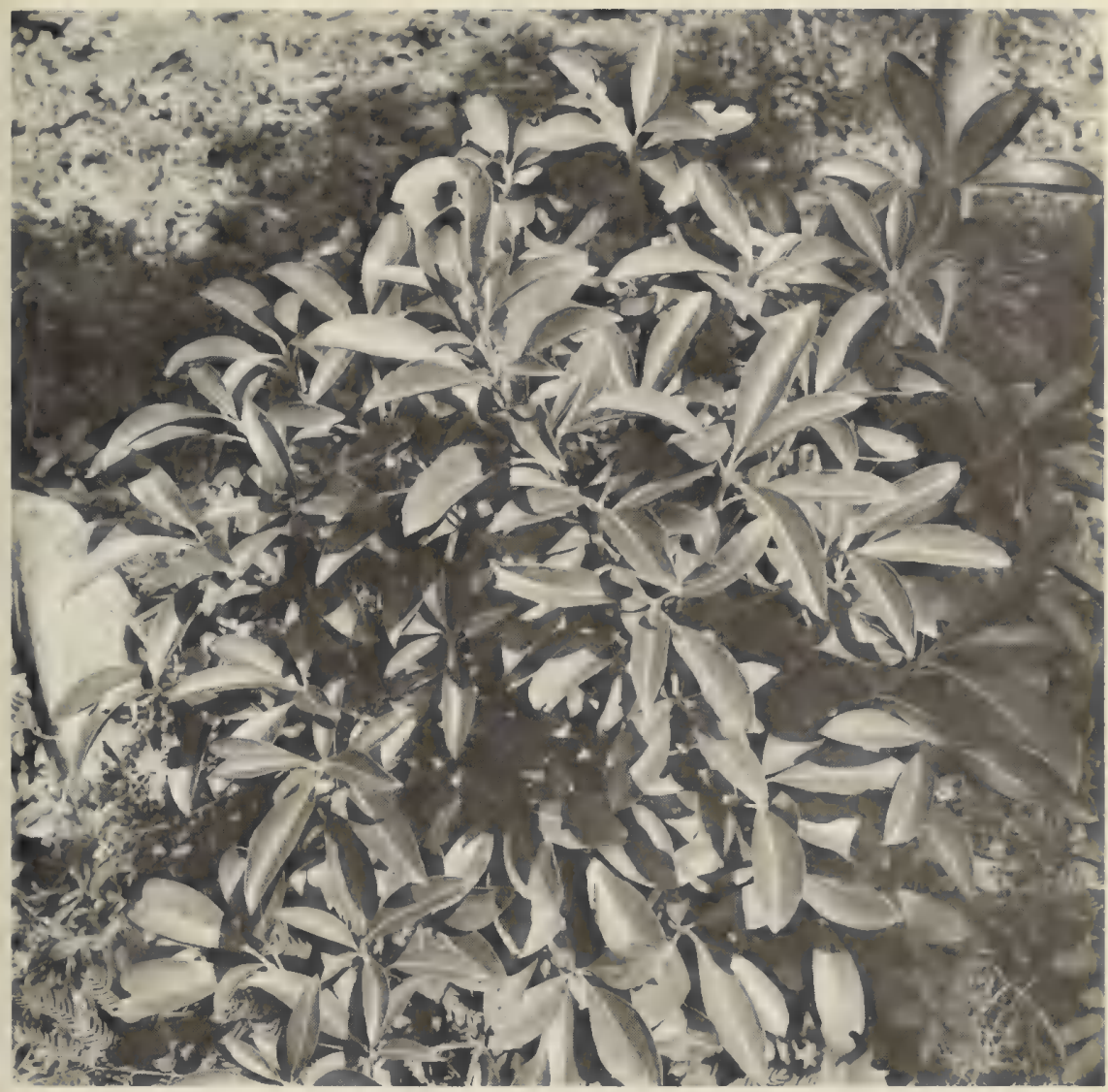

Figure 36. Mountain laurel (Kalmia latifolia) Beautiful evergreen shrub with clusters of pink flowers.

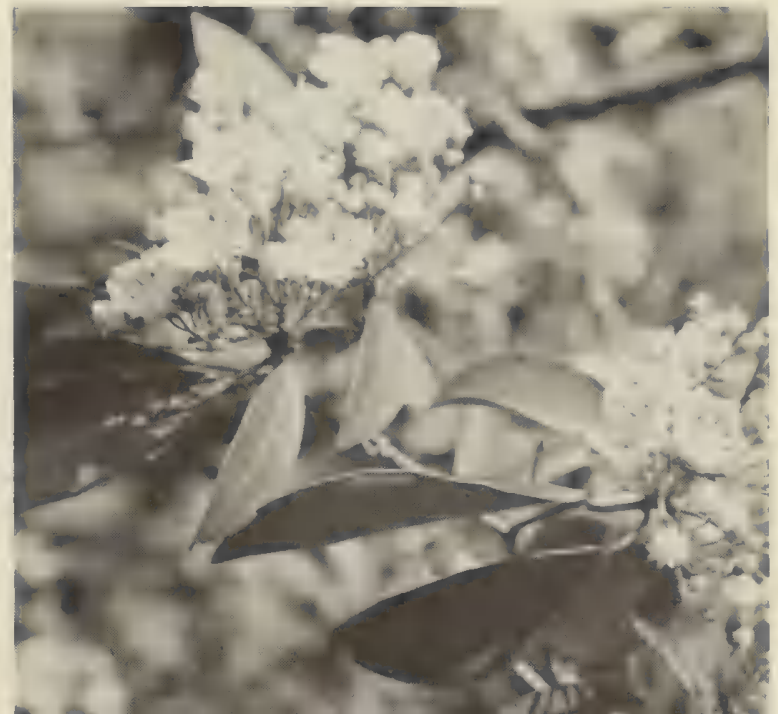


eastern Coastal Plain and bogs of the mountains to South Carolina.

Poisoning: The leaves, twigs, flowers, and pollen grains contain andromedotoxin, which is a toxic resinoid causing watering of the mouth, eyes, and nose, loss of energy, slow pulse, vomiting, low blood pressure, lack of co-ordination, convulsions, and progressive paralysis of arms and legs until death. Poison honey is made occasionally in the mountains when bees visit laurel or rhododendron. The honey is so very bitter and astringent to taste, however, that poisonous amounts would not be eaten. Children have been poisoned by sucking on the flowers and making "tea" from the leaves.

To the physician: Gastric lavage or emesis; activated charcoal; atropine; hypotensive drugs.

Rhododendron spp.-Rhododendron, laurel, rose bay, azalea (Figure 37)

Rhododendrons are evergreen shrubs often forming dense growths in Canada and southward in the Appalachians and the West Coast. The leaves are larger than in Kalmia and the larger showy flowers are in globose clusters. Rhododendron maximum $\mathrm{L}$. is the most common in the East and is the state flower of West Virginia; $R$. macrophyllum D. Don is common on the West Coast and is the state flower of Washington.

Azaleas are native deciduous shrubs of the United States or evergreen species introduced from Asia and cultivated extensively for the showy flowers.

Poisoning: Rhododendrons and azaleas contain the same toxic principle as found in Kalmia. Although cases of poisoning are rare, they should be suspected of possible danger.

\section{OLIVE FAMILY-Oleaceae}

Ligustrum vulgare L.-Privet, ligustrum, hedge

This deciduous shrub with small opposite leaves is very commonly planted as a hedge or shrub and has escaped cultivation into woods and along creeks throughout the 
area. The blue or nearly black berries have been the cause of fatal poisoning to children in Europe. Although few cases of poisoning have been recorded for this country, privet should be treated with caution and the fruits kept away from infants. There are a number of species of Ligustrum which are deciduous or evergreen and commonly planted.

\section{LOGANIA FAMILY-Loganiaceae}

Gelsemium sempervirens (L.) Ait. f.-Yellow jessamine, Carolina jessamine (Figure 38)

Description: Woody vine, trailing or high-climbing; leaves opposite, short-stalked, lanceolate, $1 / 2-21 / 2$ in. long, margin smooth; flowers in early spring, yellow and very aromatic, tubular with 5 petal lobes, $1-1 \frac{1}{2}$ in. long; fruit a thin, flattened capsule, less than 1 in. long and with a short beak at the top.

Occurrence: Yellow jessamine is found throughout the southeastern Coastal Plain and eastern Piedmont northward to Virginia; it occurs in woods, on fences, in fields and thickets. It is very common and is one of the most beautiful vines of the early spring in the southeast. It is the state flower of South Carolina. The less common G. rankinii Small, in the Coastal Plain from North Carolina to Louisiana, is similar to $G$. sempervirens but is not aromatic. It may also be poisonous.

Poisoning: The alkaloids gelsemine, gelseminine, and gelsemoidine are found throughout the plant, with greatest concentrations in the roots and nectar of the flowers. Children have been severely poisoned by chewing on the leaves and sucking the nectar from the flowers. Honeybees are also poisoned, and a poison honey is occasionally made. Symptoms are profuse sweating, muscular weakness, convulsions, depression, and paralysis of the motor nerve endings. Rootstocks are used as a source of drugs for medicinal purposes.

To the physician: Gastric lavage or emesis; symptomatic; atropine $2 \mathrm{mg}$. IM as needed; artificial respiration.

The well-known poison strychnine comes from the seeds of Strychnos nux-vomica L., also of this family. The flowers 


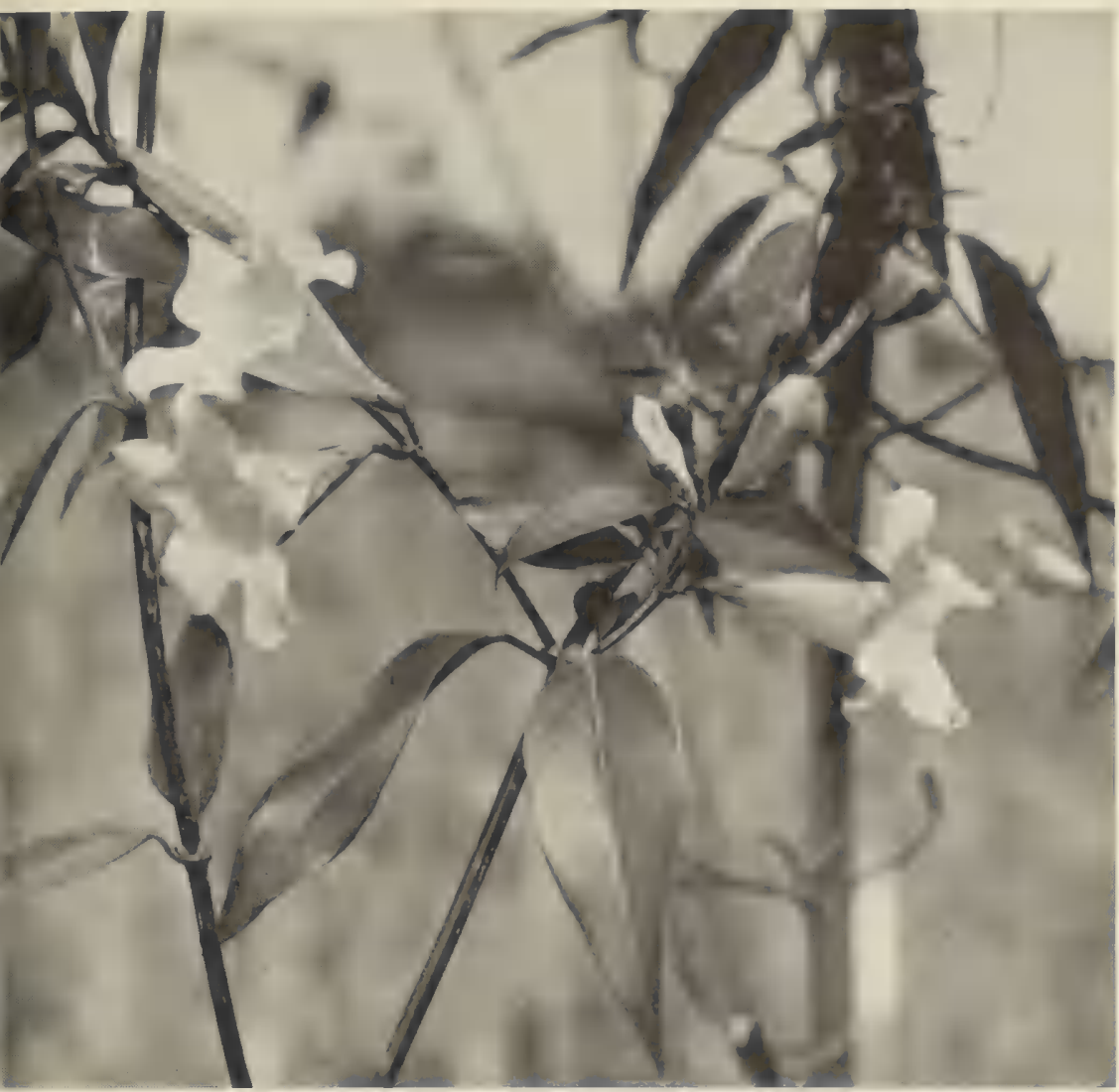

Figure 38. Yellow jessamine (Gelsemium sempervirens) A trailing or highclimbing vine with yellow and aromatic flowers.

are also poisonous. It is a native of India and is planted rarely in Hawaii.

DOGBANE FAMILY-Apocynaceae

Allamanda cathartica L.-Yellow allamanda (Figure 39)

Description: A woody vine most commonly pruned to a shrub to $15 \mathrm{ft}$. tall; leaves glossy and leathery, elliptical, 4-6 in. long, opposite or in whorls of 3-4; flowers yellow, aromatic, bell-shaped with 5-petal lobes and a tubular throat, in clusters near the ends of the branches; fruit a prickly capsule. 


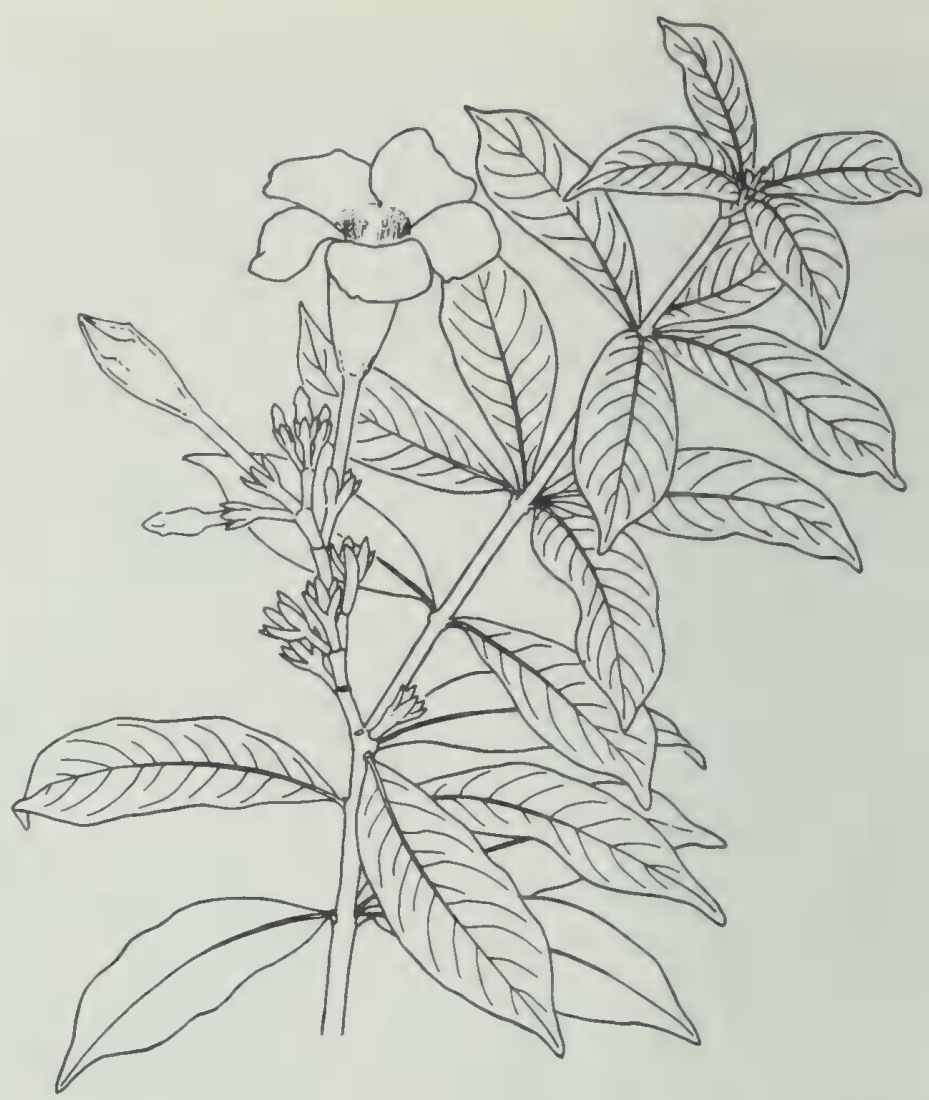

Figure 39. Yellow allamanda (Allamanda cathartica) A popular ornamental shrub of the subtropics and tropics with yellow waxy flowers. Courtesy of the Florida Agricultural Experiment Station.

Occurrence: A native of Brazil, yellow allamanda is very commonly cultivated as an ornamental in southern United States and Hawaii.

Poisoning: All parts, but mostly the fruit and cell sap in the stems and leaves, cause a minor stomach upset. The action of the extract, long known by the native tribes of South America, is the basis for the specific epithet cathartica named by Linnaeus in 1771 .

To the physician: Gastric lavage or emesis; symptomatic. Apocynum cannabinum L.-Dogbane, Indian hemp (Figure 40)

Description: Perennial herbs with milky juice; leaves 


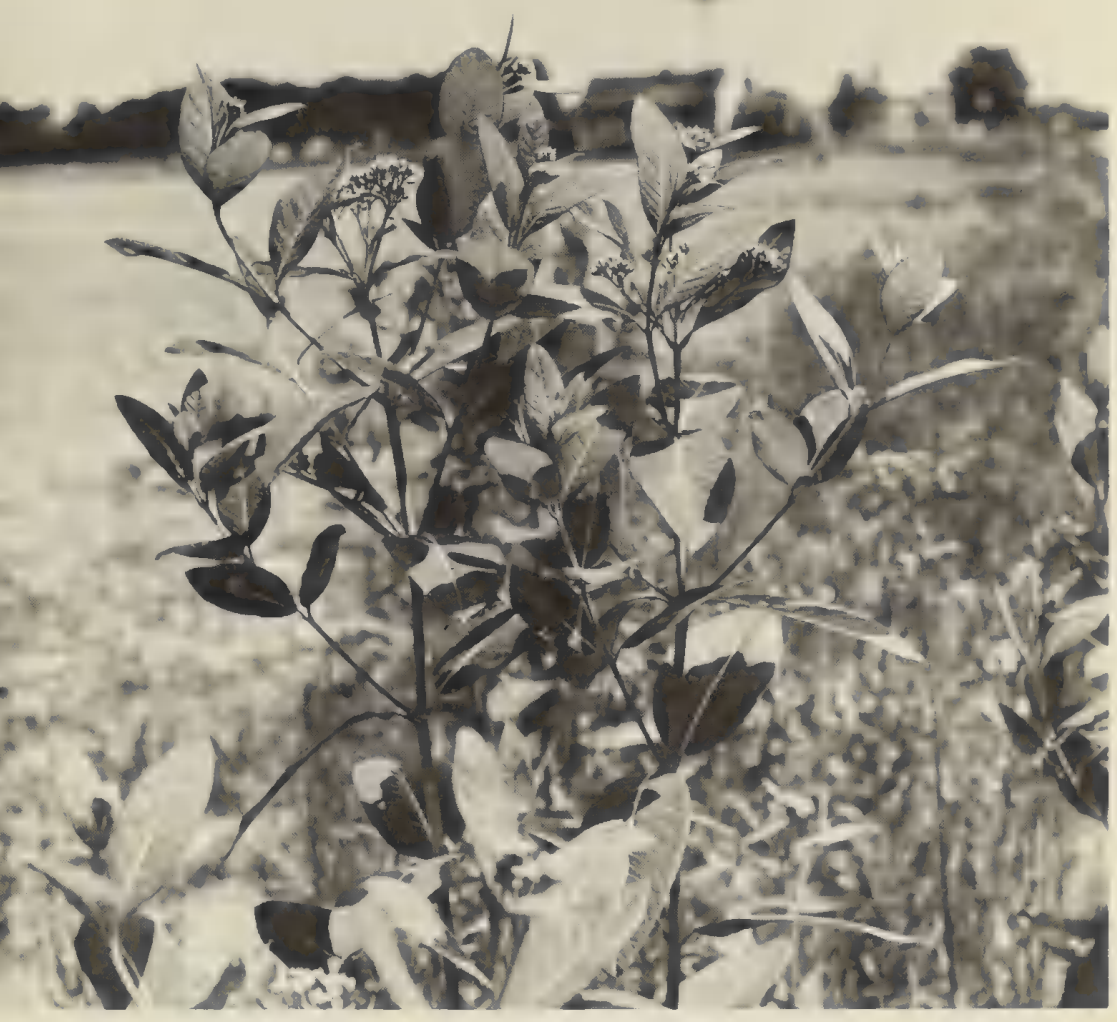

Figure 40. Dogbane (Apocynum cannabinum) A common native weed of potential danger to children.

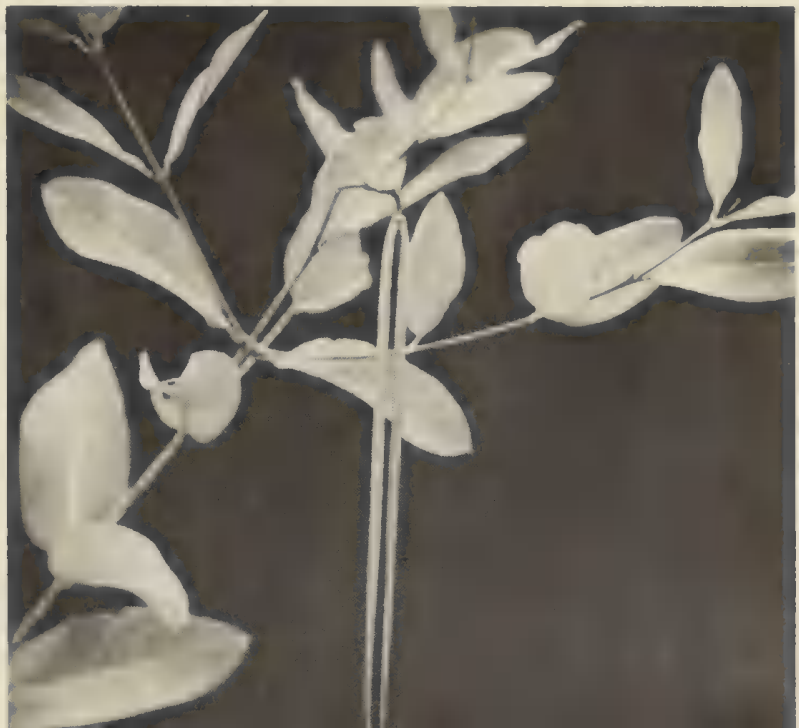


opposite, simple, margins not toothed; flowers small, pinktinged, appearing in early summer; fruit 2 long and slender follicles containing many seeds with long silky hairs.

Occurrence: Dogbane is a common weed in open fields and pastures, along roadsides, and in waste places throughout the United States and Canada. The related species may also be poisonous.

Poisoning: Although cases of poisoning to humans are not known, dogbane should be suspected since many authorities consider it poisonous to livestock.

\section{Ervatamia coronaria Stapf.—Crape jasmine (Figure 41)}

This shrub, a native of India and naturalized in many tropical areas, has waxy white flowers $1 \frac{1 / 2-2}{2}$ in. across, often double in some forms, and quite fragrant.

It is planted in southern Florida and considered potentially

Figure 41. Crape jasmine (Ervatamia coronaria) A potentially poisonous shrub cultivated in the subtropics and tropics. Courtesy of the Florida Agricultural Experiment Station.

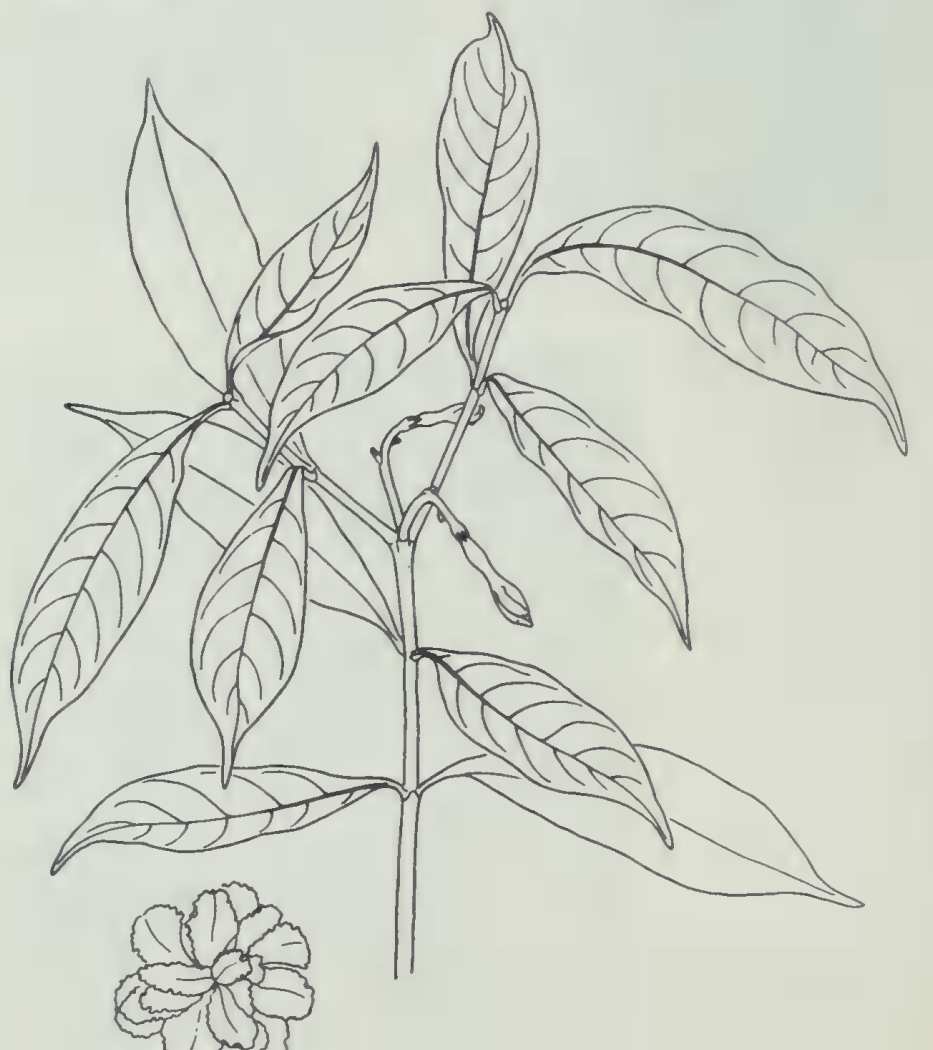


poisonous although no cases have been reported in this country.

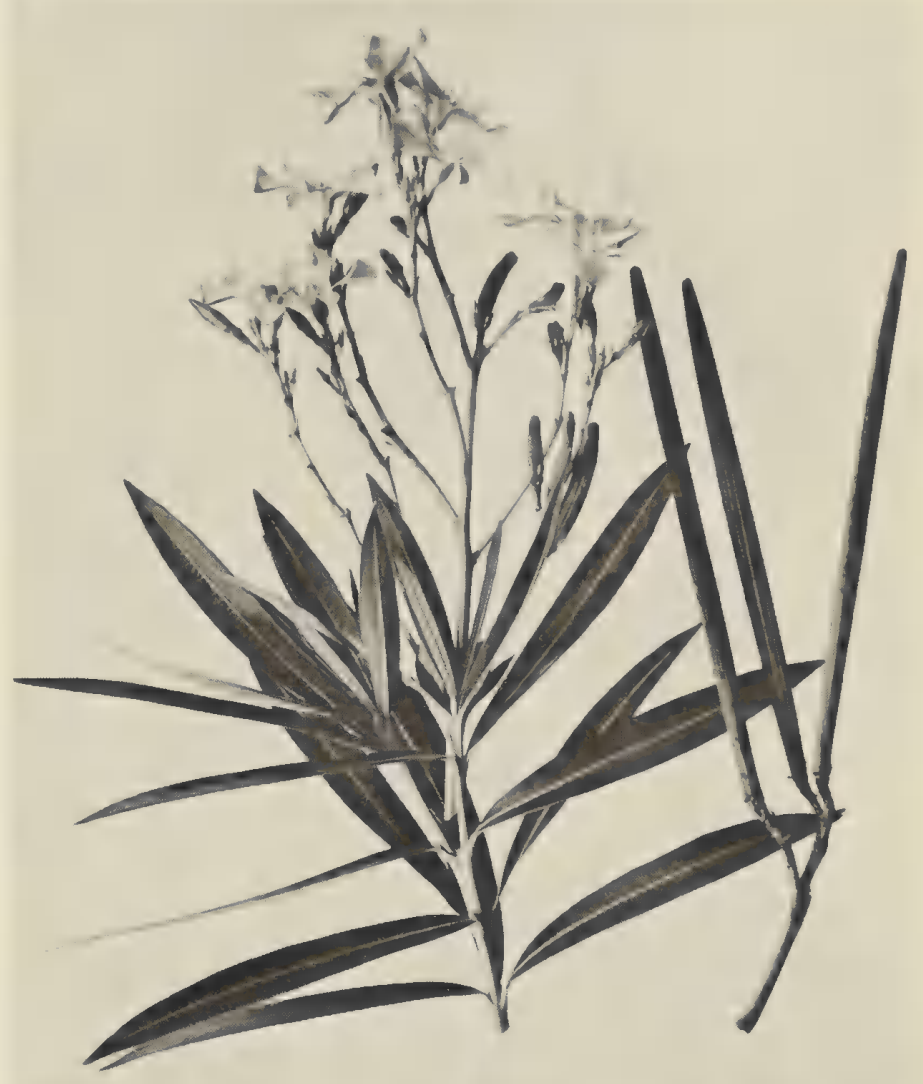

Figure 42. Oleander (Nerium oleander) A dangerous evergreen tree or shrub of warm elimates. USDA Photograph.

Nerium oleander L.-Oleander (Figure 42)

Description: An evergreen shrub or small tree to $25 \mathrm{ft}$. tall, with thick gummy clear sap; leaves short-stalked, opposite or in whorls of 3, narrow, leathery, 3-10 in. long, margins not toothed, veins light yellowish and conspicuous; flowers appearing in summer, in clusters at the tips of the 
twigs, white to pink to deep red, about $1-3$ in. across and sometimes double in certain horticultural forms.

Occurrence: Oleander is a native of southern Europe and has been commonly cultivated as an ornamental in southern United States and California. N. indicum Mill. is common in Hawaii.

Poisoning: The twigs, green or dry leaves, and flowers contain cardiac glycosides nerioside and oleandroside. These are extremely poisonous and cause nausea, severe vomiting, stomach pain, dizziness, slowed pulse, irregular heartbeat, marked dilation of pupils, bloody diarrhea, drowsiness, unconsciousness, paralysis of the lungs, and death. A single leaf is said to be sufficient to kill an adult, and severe poisoning has resulted from using the branches as skewers to roast meat over an open fire in Florida; children have been poisoned by chewing the leaves and also by sucking the nectar from the flowers. A poison honey is made by bees visiting the flowers.

To the physician: Gastric lavage or emesis; symptomatic and supportive; potassium, procainamide, quinidine sulfate, disodium salt of edelate ( $\mathrm{Na}_{2}$ EDTA) have all been used effectively.

\section{Ochrosia elliptica Labill-Ochrosia plum}

A small tree native of New Caledonia, it is grown in Florida and Hawaii for its ornamental foliage and fruits. The bright red, white-fleshed fruits (drupes) are considered poisonous.

Thevetia peruviana Schum.-Yellow oleander, lucky nut, tiger apple, be-still tree

Description: A shrub or tree to $30 \mathrm{ft}$. tall with a diffusely branched dense crown; leaves alternate, dark green, and glossy, linear, 6 in. long and $1 / 4-1 / 2$ in. wide; flowers yellow or dull orange, tubular to 3 in. long and with 5 petal lobes, in small clusters at the tips of twigs; fruit a fleshy triangular drupe turning yellow then black.

Occurrence: This attractive shrub, which is native to tropical America, is commonly cultivated as an ornamental in southern United States and Hawaii. 
Poisoning: A cardiac glycoside, thevetin, is found throughout the plant but is most concentrated in the fruit. One drupe can cause death, preceded by vomiting, weak pulse, and convulsions. Deaths have been reported in Florida and the Hawaiian Islands. It is considered to be the most frequent cause of poisonings in Hawaii.

To the physician: Gastric lavage or emesis; supportive; atropine.

Urechites spp._Yellow nightshade, wild allamanda

These are woody vines or shrubs, native of southern Florida, Central America, and the West Indies. The flowers are tubular, somewhat funnel-shaped, 5-parted, and yellow; all parts have milky juice; seed pods (follicles) long and slender.

The follicles cause burning of the mouth and throat, drowsiness, paralysis, convulsions, and heart failure if eaten in quantity.

To the physician: Gastric lavage or emesis; symptomatic.

\section{MILKWEED FAMILY - Asclepiadaceae}

Cryptostegia grandiflora $\mathrm{R}$. Br.-Rubber vine, purple or pink allamanda

Description: A woody vine with milky sap, often pruned to a shrub; leaves opposite, dark waxy green, leathery, to 5 in. long; flowers purple, funnel-shaped; fruit a sharply angled follicle.

Occurrence: This attractive vine is cultivated as an ornamental in southern United States and Hawaii and has escaped in waste places in those areas.

Poisoning: All parts may cause severe stomach and intestinal upset, and cases of death have been reported from India. The related milkweeds (Asclepias spp.) are poisonous to livestock and may be dangerous to children if eaten in quantity. Also the related Calotropis gigantea Ait., crownflower, of Hawaii is dangerous.

To the physician: Gastric lavage or emesis; symptomatic. 


\section{HONEYSUCKLE FAMILY-Caprifoliaceac}

Sambucus spp.-Elder, elderberry

Description: Shrubs with soft wood and large pith with long internodes between the opposite, pinnately divided leaves; leaflets 5-11 per leaf, toothed on the margins, deciduous; flowers small, 5-lobed, white, in large terminal clusters; fruit berry-like and juicy, red or black.

S. canadensis L.-Elder, elderberry (Figure 43)

Flowers in flat-topped clusters; fruit purple-black; pith of stem white. This is a very common shrub in woods and low fields and waste places or along ditches from Canada south to Florida and Arizona.

Figure 43. Elderberry (Sambucus canadensis) A common shrub with divided leaves and flat-fopped clusters of small white flowers. Some parts are edible, some poisonous.

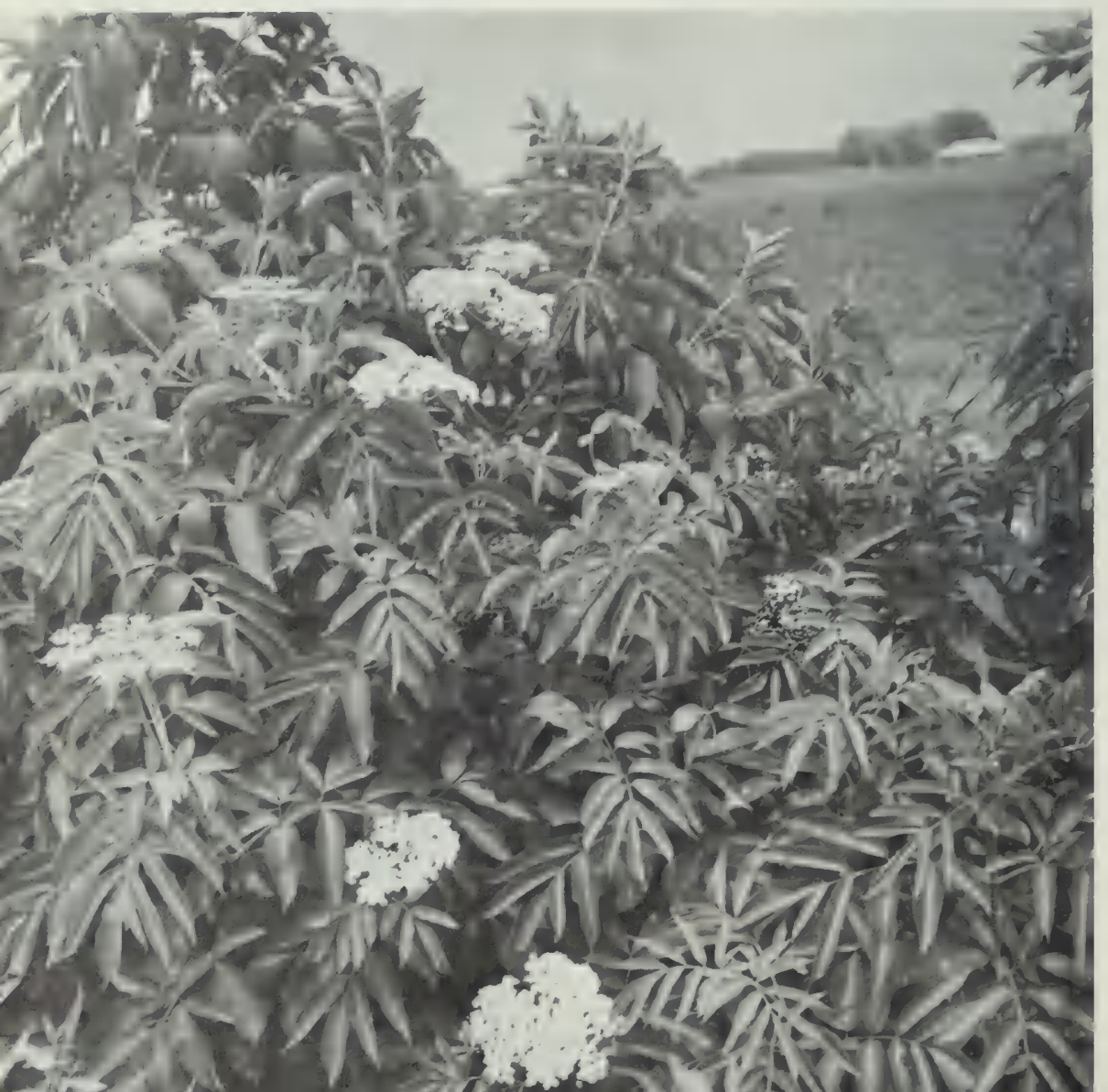


S. mexicana var. bipinnata (Schl. \& Cham.) SchwerinMexican elder

This variety is the common elder in Hawaii.

S. pubens Michx.-Red-berried elder

Flowers in ovoid clusters; fruit red; pith of stem brown. This species is fairly common in moist open woods and fields, Alaska to southern California, eastward in Canada, south in the Rockies to Colorado and New Mexico, and into North Carolina and Georgia along the higher elevations of the Appalachians.

S. simpsonii Rehd.-Gulf elder, southern elder

Similar to $S$. canadensis but the lower leaflets are again pinnately divided. It is a common shrub of roadside ditches. hammocks, and marshes from Florida to Louisiana.

There are other species in western United States and Canada, from the Rockies to the Pacific coast, and in Hawaii. All are potentially dangerous.

Poisoning: The roots, stems, and leaves, and much less the flowers and unripe berries, contain a poisonous alkaloid and cyanogenic glycoside causing nausea, vomiting, and diarrhea. Children have been poisoned by making blowguns, whistles, and popguns out of the stems and having them in their mouths. The flowers and ripe fruit are edible without harm and are frequently used for pies, wine, jelly, and pancakes.

To the physician: Gastric lavage or emesis; treat for cyanide poisoning.

\section{POTATO FAMILY - Solanaceae}

Atropa belladonna L.-Belladonna, deadly nightshade

Description: Coarse, branched herb to $5 \mathrm{ft}$. tall: leaves alternate, simple, ovate and smooth-margined, appearing crowded because of short axillary branches with leaves: flowers dull purple, tubular and about 1 in. long: fruit a purple to black berry with a persistent 5-lobed calyx.

Occurrence: Belladonna is a native of Europe and is planted as a garden ornamental in the United States. 
Poisoning: The alkaloid atropine is found throughout the plant (berries, leaves, roots, flowers) but the black berries have been the part usually eaten. Symptoms are fever, rapid heartbeat, dilation of pupils, skin flushed hot and dry. It can be fatal, with as few as 3 berries sufficient to kill a child. Atropine, in correct amounts, is one of the most useful plant drugs.

To the physician: Gastric lavage ( 4 per cent tannic acid solution) or emesis; pilocarpine for dry mouth and visual disturbance.

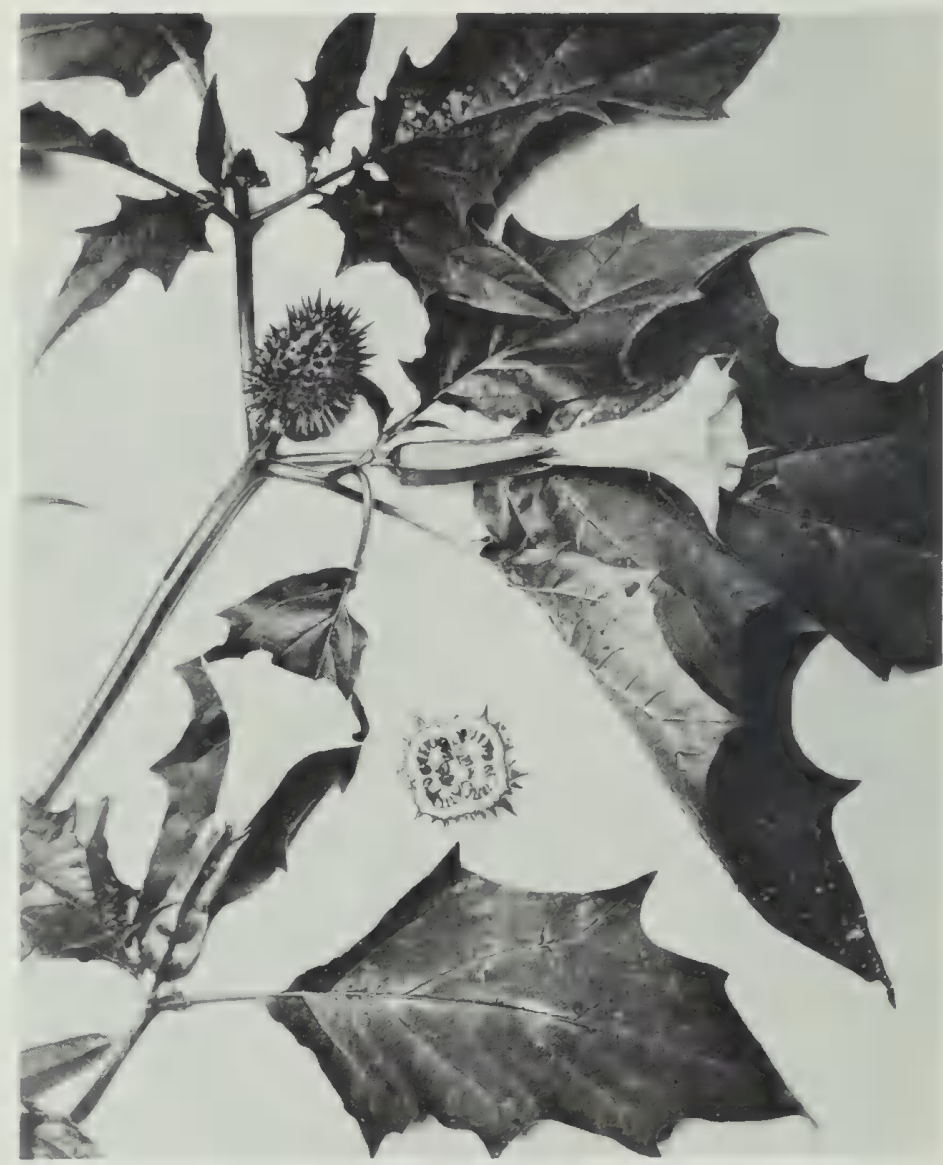

Figure 44. Jimsonweed (Datura stramonium) A frequent weed of fields and disturbed areas with white to bluish flowers and prickly fruits. USDA Photograph. 
Description: A sprawling shrub to $12 \mathrm{ft}$. tall; leaves alternate, simple and smooth-margined; flowers tubular, $1 / 3-1$ in. long, greenish white, greenish yellow, or cream; fruit a small berry.

\section{C. diurnum L.-Day-blooming jessamine}

Flowers white and aromatic during the day; berry purple. This is cultivated and has escaped in Florida and Hawaii.

C. nocturnum L.-Night-blooming jessamine, poisonberry

Flowers greenish white to cream, aromatic at night; berry white. It is cultivated as an ornamental in southern United States and is one of the most common cestrums in Hawaii.

C. parqui L'Her.-Green cestrum, willow-leaved jessamine

Similar to $C$. nocturnum but the leaves are less than $1 \mathrm{in}$. wide. It is cultivated as an ornamental and found growing wild in woods and along roadsides from Florida to Texas.

Poisoning: Eating of any part of these plants can result in symptoms resembling atropine poisoning with headache, nausea, dizziness, hallucinations, muscular spasms and nervousness, high temperature, watering of mouth, and paralysis. Cases of poisoning among children and pets are on record.

To the physician: Gastric lavage or emesis; symptomatic.

Datura stramonium L.-Jimsonweed, Jamestown weed, thornapple, stinkweed, datura (Figure 44)

Description: Large annual to $5 \mathrm{ft}$. tall, wide-branching near the tip; stem green to purplish, ill-scented; leaves alternate, simple, ovate-elliptic, 3-8 in. long, short-stalked, with irregular large teeth on the margin; flowers funnelshaped, white to bluish purple; fruit a dry, ovoid capsule covered with many sharp prickles.

Occurrence: Jimsonweed is a very common weed of fields, pastures, gardens, roadsides, and waste places; widespread throughout North and South America and Hawaii.

\section{D. metaloides Dunal}

Found in fields, along roadsides, and on plains from Colorado south to Texas, Mexico, and California. 
D. metel L.-Metel, downy thornapple, devil's trumpet

An ornamental shrublike herb of the eastern United States and Hawaii.

D. suaveolens H.\&B.-Angel's trumpet (Figure 45)

An ornamental shrub or small tree cultivated in southern United States and Hawaii for the large (to I ft. long) trumpetlike white flowers.

Poisoning: All parts, particularly the seeds and leaves, contain the alkaloids hyoscyamine, atropine, and hyoscine (scopolamine). Symptoms are thirst, pupil dilation, dry mouth, redness of skin, headache, hallucinations, nausea, rapid pulse, high blood pressure, delirium, convulsions, coma, and death. Children have been poisoned by sucking nectar from the flowers, eating the seeds or making "tea" from the leaves. Even a very small amount (4-5 grams) of leaves or seeds can be fatal to a child. A family of four was poisoned when seeds of jimsonweed were mistakenly added to homemade soup. The leaves and seeds are used as a source of drugs for medicinal purposes.

Jimsonweed has an interesting place in American history. During the time of the Virginia uprising known as Bacon's Rebellion, which occurred in Jamestown in 1676, the soldiers sent to stop the rebellion unfortunately ate the berries of this plant for lack of other food and became deathly ill. The name "jimsonweed" is therefore a corruption of the older and more meaningful "Jamestown weed."

To the physician: Gastric lavage or emesis; pilocarpine for dry mouth and visual disturbance, morphine, caffeine, etc.

Hyoscyamus niger L.-Black henbane, henbane

Description: Erect annual or biennial herb with coarse, hairy stems 1-5 ft. tall; leaves alternate, simple, oblong with a few coarse teeth, not stalked; flowers in the leaf axils, corolla tubular and 5-lobed, greenish yellow or yellowish with purple veins; fruit a rounded capsule inclosed by a 5 lobed calyx.

Occurrence: Black henbane is cultivated and has escaped along roads, in waste places, and around buildings across 
Nicandra physalodes (L.) Gaertn.-Apple-of-Peru, shoofly plant

This large herb is closely related to Physalis and differs by its pale blue (rather than yellow) corolla and dry (rather than juicy) berry. It has been introduced from Peru and has become established, out of cultivation, as an occasional weed in barn lots and fields throughout most of the United States and Hawaii. The poisoning is expected to be similar to that in Physalis, although no cases have been reported.

\section{Nicotiana tabacum L.-Tobacco}

Aside from the effects from smoking, tobacco leaves have caused severe poisoning when eaten as cooked greens. The related $N$. glauca Graham (tree tobacco) is a shrub or small tree cultivated as an ornamental in Florida and California and is a weed in California and Hawaii. It has been the cause of illness in children sucking the flowers, and death when leaves were chopped up and used in a green salad. $N$. trigonophylla Dunal (wild tobacco) of dry desert soils in southwestern United States caused poisoning and one death in a California family that ate the leaves as boiled greens. Additional species are possibly equally dangerous.

Poisoning: The alkaloid nicotine is extremely poisonous, causing severe vomiting, diarrhea, slow pulse, dizziness, collapse, and respiratory failure.

To the physician: Gastric lavage or emesis; activated charcoal, artificial respiration and oxygen, tannin administered orally.

Physalis spp.-Ground cherry, Jerusalem cherry, Chinese lantern, strawberry tomato

Description: Perennial herbs with erect stem spreading at the top, often much branched; leaves alternate, simple, smooth-margined or irregularly toothed; flowers axillary, nodding, mostly solitary, corolla short, funnel-shaped or bell-shaped, yellowish or yellow-green with a dark center; fruit a globose juicy berry turning yellow and mostly enclosed by the enlarged calyx. 
Occurrence: There are a number of species native in pastures, meadows, fields, woods, and roadsides throughout the United States. Some types are cultivated as ornamentals. $P$. peruviana $\mathrm{L}$. is common in Hawaii and is used for jelly and preserves.

Poisoning: The leaves and unripe fruit are poisonous.

To the physician: Gastric lavage or emesis; symptomatic.

Solandra spp.-Trumpet flower, chalice vine

These very large funnel- to bell-shaped, showy, white or yellow flowers are cultivated as house plants or outside in southern United States and Hawaii.

Poisoning is similar to that in Solanum and has resulted from children eating the leaves and tlowers.

\section{Solanum spp.-Nightshade}

Description: Herbs or shrublike plants with simple alternate leaves; flowers with calyx and corolla 5-lobed and wide-spreading, the large yellow anthers erect and conspicuous; fruit a berry.

S. americanum Miller and S. nigrum L.-Nightshade, black nightshade (Figure 46)

Annual branched herbs with dark dull green leaves, ovate or lanceolate, toothless to slightly toothed on the margins; flowers small and white; fruit black when ripe, glossy and in an umbel ( $S$. americanum) or dull and in a raceme (S. nigrum). S. americanum is a common native weed of waste places, old fields, ditches, and roadsides, fence rows, or edges of woods throughout the United States. The European $S$. nigrum is established as a weed in similar habitats in the United States and Hawaii.

S. carolinense L.-Horse nettle, wild tomato (Figure 47)

This is a very common prickly weed throughout the United States. The yellow berries are conspicuous and sometimes used as a source of drugs for medicinal purposes. A child died a few years ago in Philadelphia from eating the berries. 


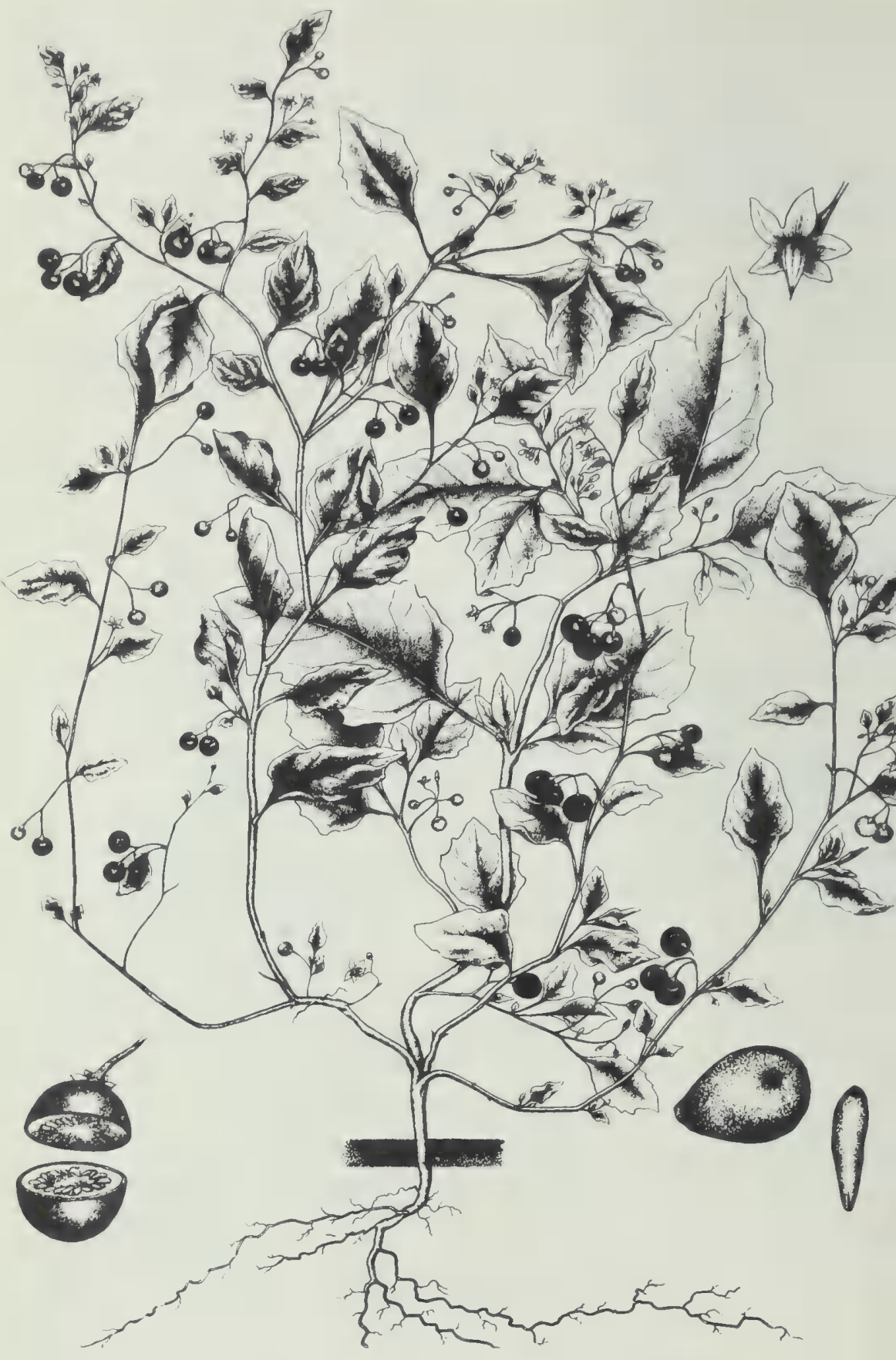


S. dulcamara L.-Deadly nightshade, climbing nightshade, European bittersweet (Figure 48)

A woody vine or shrub with purple flowers and red berries. It is a native of Eurasia and has become naturalized on moist stream or pond banks and in low damp woods from Canada to California, Kansas, Tennessee, and North Carolina.

S. pseudocapsicum L.—Jerusalem cherry

Growing wild in Hawaii or as an ornamental potted plant throughout the United States, this species is prized for its bright red berries.

S. sodomeum L.-Apple of Sodom, yellow-fruited popolo

This is a common weed in Hawaii. It is a prickly shrub with blue flowers.

S. tuberosum L.-Potato, irish potato, white potato

This common vegetable is grown throughout the area and only rarely escapes cultivation.

All other species of Solanum should be suspected of being poisonous.

Poisoning: Solanine, a glyco-alkaloid, is found throughout the plant, with the highest concentrations in the unripened fruit. Symptoms are stomach pain, lower temperature, paralysis, dilated pupils, vomiting, diarrhea, shock, circulatory and respiratory depression, loss of sensation, and death. Solanine is extremely toxic and small amounts can be deadly.

Misconceptions occur concerning the poisonous qualities of the solanums, probably because of the harmless nature of the completely ripe fruit of certain species. Many are considered edible. However, cases of poisoning from eating the unripened fruits have been reported from the Hawaiian Islands and North America. Children have been poisoned from black nightshade, deadly nightshade, and horse nettle. Green and spoiled potatoes, and potato sprouts have caused severe cases of poisoning. Never eat potato tubers if they look spoiled or green below the skin, and always discard the sprouts.

To the physician: Gastric lavage or emesis; symptomatic; support respiration, paraldehyde $(2-10 \mathrm{ml}$. IM). 


\section{SNAPDRAGON FAMILY-Scrophulariaceae}

\section{Digitalis purpurea L.-Foxglove}

Description: Biennial herb with alternate, simple, toothed leaves; flowers in a showy terminal raceme, tubular to 3 in. long, pendent, purple, pink, rose, yellow, or white and spotted on the inside bottom of the tube; fruit a dry capsule.

Occurrence: Foxglove is a native of Europe and is commonly planted in the United States and Hawaii as a garden ornamental. It is naturalized and locally abundant in cleared lands in western United States.

Poisoning: Foxglove has long been known as a source of cardiac or steroid glycosides, some commonly used today for medicinal purposes. Poisoning in adults results mostly from overdoses of the drug digitalis, or much more rarely in children from sucking the flowers or eating the leaves or seeds. Symptoms include nausea, diarrhea, stomach pain, severe headache, irregular heartbeat and pulse, tremors, convulsions, and death.

To the physician: Gastric lavage or emesis; supportive; atropine, potassium, procainamide, quinidine sulfate, disodium salt of edelate ( $\mathrm{Na}_{2}$ EDTA) have all been used effectively.

\section{VERVAIN FAMILY - Verbenaceae}

Duranta repens $\mathrm{L}$. - Golden dewdrop, pigeonberry, duranta, skyflower

Description: Drooping shrub to $18 \mathrm{ft}$. tall with stems trailing and often thorny; leaves opposite, rounded, coarsely toothed, to $4 \mathrm{in.}$ long; flowers lilac-blue with yellow eye, to $1 / 2$ in. across; fruit yellow-orange, to $1 / 2$ in. across, an 8 seeded berry inclosed by the calyx, in a drooping raceme.

Occurrence: Duranta is a native of tropical America and is cultivated in southern United States and Hawaii as an ornamental shrub or for hedges. It is especially attractive when loaded with masses of yellow-orange berries. Certain horticultural forms have larger flowers or of different colors.

Poisoning: The berries contain a saponin causing drowsi- 
ness, fever, and convulsions. Deaths of children from eating the berries are on record.

To the physician: Gastric lavage or emesis; symptomatic.

Lantana camara L._Lantana, red sage (Figure 49)

Description: Perennial shrub with square twigs and a few scattered spines; leaves simple, opposite or whorled, with toothed margins, ovate, $1-5$ in. long; inflorescence a flattopped cluster of small flowers $1-2$ in. across and on a long stalk; flowers small and tubular, 4-parted, white, yellow, or pink changing to orange or red; fruit a drupe, greenish and becoming blue-black when ripe, about $1 / 4-3 / 8$ in. across, fleshy.

Occurrence: Lantana is cultivated as an ornamental shrub in pots or porches or patios in the northern United States and Canada, or as a lawn shrub in the southeastern Coastal Plain, Texas, California, and Hawaii. It is a native of dry woods in the southeastern United States and has escaped cultivation and become weedy in some areas. It is considered to be one of the chief causes of poisoning in Florida.

Poisoning: The fruit contains an alkaloid lantanin or lantadene A. The green, unripened fruit is the most dangerous. Symptoms are stomach and intestinal irritation, muscular, weakness, circulatory collapse, and death. Acute symptoms resemble atropine poisoning. All species are suspected of poisoning.

To the physician: Gastric lavage or emesis; symptomatic and supportive.

\section{LOBELIA FAMILY - Lobeliaceae}

Lobelia spp.-Lobelia, Indian tobacco, cardinal flower

Description: Herbs with alternate, simple leaves; flowers in a terminal raceme, corolla white, blue, or red, tubular and 2-lipped, with 2 lobes forming the upper lip and 3 forming the lower; fruit a capsule.

Occurrence: There are numerous species of lobelia native in fields, woods, and roadsides throughout the United States. 


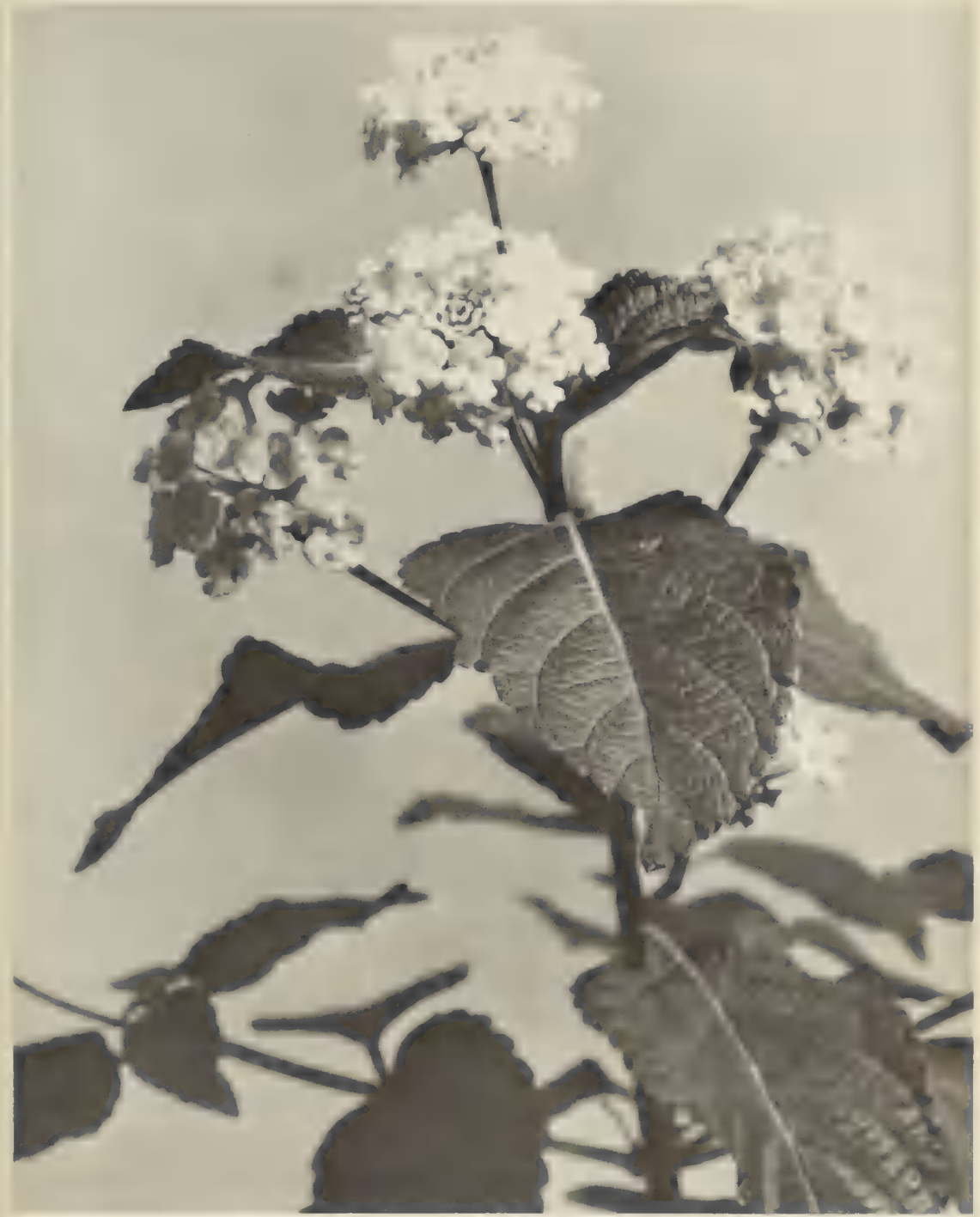

Figure 49. Lantana (Lantana camara) Weed or ornamental shrub with attractive yellow, orange, or red flowers and blue-black berries. USDA Photograph.

Poisoning: All parts of the plant contain the alkaloids lobelamine, lobeline, and others. Symptoms include nausea, progressive vomiting, exhaustion and weakness, prostration, stupor, tremors, convulsions, coma, and death. Most cases of 
human poisoning have resulted from overdoses of a homemade medicinal preparation from $L$. inflata L. (Indian tobacco), which is sometimes used as a commercial source of a medicinal drug.

To the physician: Gastric lavage or emesis; artificial respiration; atropine $2 \mathrm{mg}$. IM as needed.

\section{ASTER FAMILY - Asteraceae, Compositae}

Arnica montana L.-Leopard's-bane, mountain tobacco, mountain snuff, arnica root

Description: Perennial, erect herb to $2 \mathrm{ft}$. tall, unbranched or slightly branched, hairy; basal leaves clustered, 2-5 in. long, stem leaves opposite, few and smaller; flower heads deep yellow, solitary or $3-4$ in a cluster, each $2-3$ in. across; fruit a small achene.

Occurrence: A native of Europe, arnica is occasionally cultivated in rock gardens or borders of flower beds in northern United States and Canada.

Poisoning: The extract of this European plant is used in medicine, but the flowers and roots have caused vomiting, drowsiness, and coma when eaten by children.

To the physician: Gastric lavage or emesis; symptomatic.

Eupatorium rugosum Houtt.-White snakeroot, fall poison (Figure 50)

Description: Perennial herb to $4 \mathrm{ft}$. tall with opposit leaves which are ovate, long-stalked, and coarsely toothed on the margins; flowers small, white, in small heads which are arranged in rounded clusters at the top of the plant; fruit a small achene.

Occurrence: White snakeroot is a showy weed of roadsides, fields, open woods, and pastures from Canada southward to Georgia, eastern Texas, and Minnesota; common in the Appalachians and upper Midwest, less frequent in the Piedmont and eastern Coastal Plain.

Poisoning: The eritire plant contains tremetol, a complex alcohol, and certain glycosides. A common condition in early colonial times, called "milk sickness," became one of 


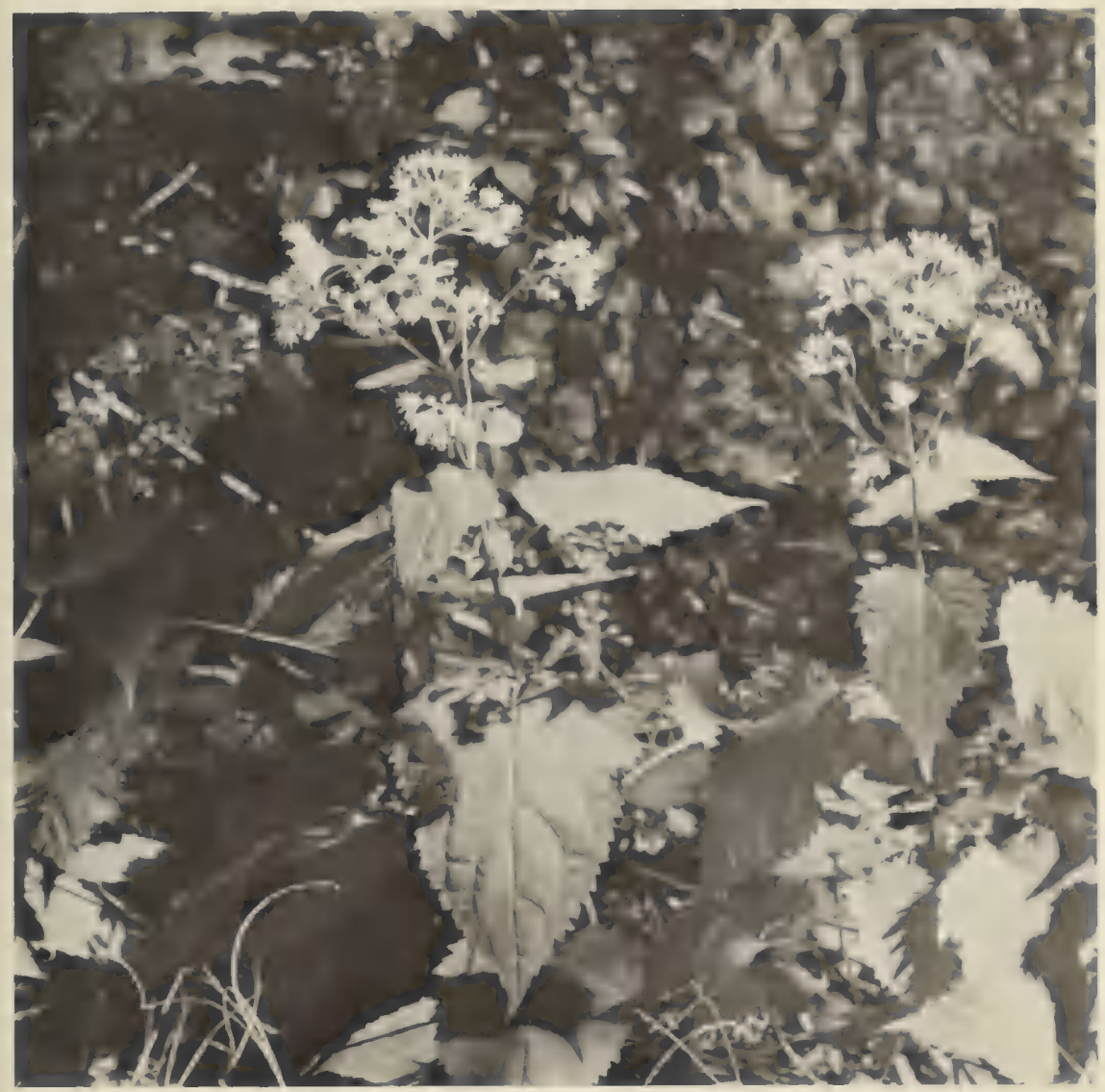

Figure 50. White snakeroot (Eupatorium rugosum) A common herb and the cause of "milk sickness" in eastern United States.

the most important causes of human death, reaching its peak during the early 1800's. The greatest number of recorded cases were in North Carolina, Illinois, Indiana, and Ohio. There is a "Milk-sick Ridge" in western North Carolina which attests to the difficulties of those times. This illness was caused by the cows eating white snakeroot so that the poisonous chemical was concentrated in the milk. Symptoms resulting from drinking this poisonous milk included weakness, nausea, severe vomiting, tremors, jaundice, constipation, prostration, delirium, and death. 
With processed milk, the condition is now rare, the only danger occurring when raw milk is used from the family cow.

To the physician: Symptomatic; treat for liver damage and anuria.

Haplopappus heterophyllus (Gray) Blake-Rayless goldenrod, jimmy weed, burrow weed

Description: Erect bushy plant 2-4 ft. tall; leaves alternate, slender, and sticky; flowers yellow, in many small heads of 7-15 flowers, clustered at the tips of the stems.

Occurrence: Rayless goldenrod is common in fields or ranges, around watering sites, and along stream banks from Kansas, Oklahoma, and Texas to Colorado, New Mexico, Arizona, and into Mexico. Other species of Haplopappus may be equally dangerous.

Poisoning: Like Eupatorium rugosum, tremetol is present throughout the plant and similar milk sickness has been a problem in sections of the southwestern United States.

To the physician: Gastric lavage or emesis; symptomatic; treat for liver damage and anuria.

\section{Poisonous and non-poisonous berries}

The list which follows includes many native and cultivated berries in the United States and Canada which are often eaten, particularly by children. These are listed here so that one can find out quickly whether a particular kind is poisonous or safe. Although poisonous berries account for many of the cases of poisoning in children, the vast majority of the different kinds are edible. All fleshy fruits (berries, drupes, and pomes) are included under the commonly used term "berry."

It is probably safest to teach children to eat only plants served to them, yet we would never want to deprive any child of the joys of gathering and eating wild fruits. Extensive berry picking should be limited, however, to the 
commonly eaten types such as strawberry, blackberry, dewberry, red and black raspberry, cranberry, gooseberry, blueberry, huckleberry, citrus, persimmon, pawpaw, plum, apple, and grape. All of these are perfectly safe.

Many berries have long been looked upon with suspicion or thought of as poisonous, perhaps through folklore or because they just look poisonous. However, many of these are edible, in the sense of being nonpoisonous, although sometimes not very palatable. In a few cases some of our common berries are unclassified as to their poisonous or edible nature and should be treated with caution. Never eat large quantities of an unknown berry.

Remember that birds, squirrels, and pets often can eat many poisonous fruits without harm, so do not trust what you see them eat. Also keep in mind that it takes fewer berries to poison a child than an adult.

Some of the common uses are given under "Notes on Edibility." For more information see Fernald and Kinsey (1958), Gillespie (1959), Harrington (1967), Heller (1953), Morton (1962), and others on edible plants.

\section{NOTES ON EDIBILITY OF BERRIES}

Achras spp.-Sapodilla, dilly: Raw, only when fully ripe Actaea spp.-Baneberry: Poisonous, see pp. 4446 Akebia quinata-Akebia: Raw

Aleurites spp.-Tung nut, candlenut: Poisonous, see pp. 89 90

Amelanchier spp.-Serviceberry, shadberry: Raw, pies, pudding, jelly

Ampelopsis spp.-Ampelopsis, cissus: Unknown, caution! Anacardium occidentale - Cashew apple: Raw, jelly, preserves Annona spp.-Custard apple, pond apple, sweetsop, soursop, cherimoya: Raw, jelly

Aralia spp.-Sarsaparilla, Hercules' club, spikenard: Jelly; poisonous if raw, see p. 83

Arctostaphylos spp.-Bearberry, kinnikinik, manzanita: Raw, jelly, cider, cooked Ardisia escallonioides-Marlberry, dogberry: Raw, but not good 
Areca catechu-Betel nut: Poisonous, see p. 42 Arecastrum romanzoffianum-Queen palm: Caution! Arisaema triphyllum-Jack-in-the-pulpit: Raw, but peppery Aronia spp.-Chokeberry: Jelly

Artabotrys uncinatus-Ylang-ylang: Inedible, but not poisonous

Artocarpus spp.—Breadfruit, jackfruit, jakfruit: Raw, jelly, dried

Asimina spp.-Pawpaw, dog apple: Raw, pies, caution! Asparagus officinalis-Asparagus: Caution!

Atropa belladonna-Belladonna: Poisonous, see pp. 111-112 Averrho carambola-Carambola: Raw, jelly, drink

Belamcanda chinensis-Blackberry lily: Caution!

Berberis spp.-Barberry: Raw, wine, jelly, pies

Berchemia scandens-Supplejack: Caution!

Blighia sapida-Akee: Caution! see p. 78

Bourreria ovata-Bahama strongbark, strongbark: Raw, but not good

Bumelia spp.-Buckthorn, blackhaw, saffron plum: Raw Byrsonima lucidum-Locust berry: Raw, but "soapy" taste

Calla palustris-Wild calla: Dried

Callicarpa americana-Beautybush, French mulberry: Raw, but not good

Calocarpum sapota-Red sapote: Raw, jam

Calophyllum inophyllum-Mast-wood: Caution!

Cananga odorata-Lanalana: Raw, but not good

Capsicum frutescens-Chili pepper: Caution!

Carica papaya-Papaya: Raw or cooked

Carissa grandiflora-Natal plum, carissa: Raw, jelly, preserves, sauce

Caryota spp.-Fishtail palm: Caution!

Casasia clusiaefolia-Seven-year apple: Raw fruit pulp Caulophyllum thalictroides-Blue cohosh: Poisonous, see p. 48

Celastrus scandens-Bittersweet: Poisonous, see p. 74 Celtis spp.-Hackberry, sugarberry: Raw but astringent Cephalocereus spp.-Tree cactus: Raw, only when ripe 
Cestrum spp._Jessamines: Poisonous, see p. 113

Chaenomeles spp.-Flowering quince: Jelly, jam

Chenopodium capitatum-Strawberry blite: Raw, cooked

Chionanthus virginicus-Fringe tree, old man's beard:

Unknown

Chrysobalanus spp.-Cocoplum, gopher apple, ground oak: Raw, jelly

Chrysophyllum spp._-Olive plum, satin leaf, star apple: Raw, jelly

Citharexylum fruticosum-Florida fiddlewood: Raw, but not good

Citrus aurantifolia-Key lime, lime: Juice, pies

Citrus aurantium-Sour orange, Seville orange: Juice, marmalade

Citrus spp.-Orange, lemon, grapefruit: Raw, marmalade, juice

Citrus trifoliatus - Trifoliate orange: Very sour

Clintonia borealis-Clintonia: Unknown. caution!

Clusia rosea-Pitch apple: Caution!

Coccoloba spp.-Sea grape, shore grape, pigeon plum: Raw, jelly, juice, wine

Coccothrinax argentata-Silver palm, thatch palm: Raw, but not good

Cocculus spp.-Moonseed: Caution! may be poisonous Cocos nucifera-Coconut palm: Raw, cooked

Comandra spp.--Bastard toadflax: Caution!

Cordia sebestena-Scarlet cordia, geiger tree: Raw, if ripe Cornus spp.-Dogwood, bunchberry: Raw, cooked

Cotoneaster spp.-Cotoneaster: Unknown

Crataegus spp.-Hawthorn: Raw, jelly

Cycas circinalis_Cycad, false sago palm: Poisonous, see p. 34 Cydonia oblonga-Quince: Jelly

Daphne mezereum-Daphne: Poisonous, see pp. 72-73

Diospyros spp._Persimmon, black sapote: Raw, pies, pudding - when ripe

Diphylleia cymosa-Umbrella leaf: Caution!

Disporum spp.-Disporum, yellow mandarin: Caution!

Dovyalis spp.-Kei-apple, ketembilla: Jelly, preserves 
Duchesnea indica-Indian strawberry: Raw, but not good Duranta repens-Pigeonberry: Poisonous, see pp. 121-122

Elaeagnus spp.-Oleaster, silverberry, Russian olive: Jelly Empetrum spp.-Crowberry, curlewberry: Raw, pies, jelly Ephedra spp.-Ephedra: Caution!

Eriobotrya japonica-Loquat, Japan plum: Raw, jelly

Eugenia spp.-Surinam cherry, white stopper, Java plum: Raw, jelly

Euonymus spp.-Strawberry bush: Poisonous, see p. 74

Feijoa sellowiana-Guarsteen, pineapple-guava: Raw, jam Ficus spp.-Fig: Raw, preserves

Flacourtia indica-Ramontchi: Jelly

Forestiera spp.-Wild olive: Caution!

Fortunella spp.-Kumquat: Raw, but acid

Fragaria spp.-Strawberry: Raw, jelly, pies, preserves

Gaultheria spp--Moxieplum, teaberry, wintergreen, salal: Raw

Gaylussacia spp.-Huckleberry, crackberry: Raw, jelly, pies Ginkgo biloba-Ginkgo, maidenhair tree: Raw (kernel, not outside)

Harrisia spp.-Apple cactus, prickly apple: Raw

Hedera helix-English ivy: Poisonous, see pp. 83-84

Heteromeles arbutifolia-Christmas berry: Raw, cooked, wine

Hippomane mancinella-Manchineel: Poisonous, see pp. 92-93

Hylocereus undatus - Night-blooming cereus, pitaya: Raw Ilex spp.-Holly: Caution! see p. 74

Jatropha spp.-Purge nut: Poisonous, see pp. 94-95 Juniperus spp._Juniper, cedar: Used for flavoring

Karwinskia humboldtiana-Coyotillo: Poisonous, see p. 75

Lantana spp.-Lantana: Poisonous, see pp. 122-123

Ligustrum spp._Privet: Caution! see pp. 100, 102

Lindera benzoin-Spicebush, benzoin: Dried for tea 
Linum spp.-Flax: Cooked

Liriope spp.-Lily turf: Caution!

Litchi sinesis_-Litchi, lychee: Raw, dried (litchi nuts)

Lonicera spp.-Honeysuckle, waterberry: Raw, but not good Lucuma nervosa-Eggfruit, canistel: Raw

Lycium spp.-Matrimony vine, box-thorn: Caution!

Mahonia spp.-Mahonia, Oregon holly: Unknown, caution! Maianthemum canadense-Wild lily-of-the-valley: Caution! Malpighia glabra-Barbados cherry: Jam

Malus spp.-Apple, crab apple: Raw, jelly, pies

Mammea americana-Mammee apple, mamey: Jelly, preserves

Mangifera indica-Mango: Raw, jelly, stewed

Medeola virginiana-Indian cucumber: Unknown, caution! Melia azedarach-Chinaberry: Poisonous, see pp. 77-78

Melicocca bijuga-Spanish lime, mamoncillo: Raw

Melothria pendula-Creeping cucumber, melonette: Raw, but strong laxative

Menispermum canadense-Moonseed: Poisonous, see pp $43-44$

Metopium toxiferum-Poisonwood: Poisonous, see p. 18 Mitchella repens-Partridgeberry: Raw, but dry

Momordica charantia-Balsam pear: Poisonous, see pp. 88-89

Monstera deliciosa-Ceriman, monstera: Raw, if fully ripe Morus spp.-Mulberry: Raw, pies, jelly_if ripe

Myrtus communis-Myrtle: Raw, flavoring

Nandina domestica-Nandina: Unknown

Nicandra physalodes-Apple-of-Peru: Poisonous, see p. 116 Nyssa spp.-Sour gum, black gum, tupelo: Raw, but acrid

Ochrosia elliptica-Ochrosia plum: Poisonous, see p. 108 Opuntia spp.-Opuntia cactus, prickly pear: Raw or cooked, jelly

Osmanthus spp.-Osmanthus, devilwood: Unknown

Panax quinquefolia-Ginseng: Raw, but not good Parthenocissus quinquefolia-Virginia creeper: Poisonous, see pp. 75-76 
Passiflora spp.-Passion fruit, maypop: Raw, drink Peltandra virginica-Arrow arum, green arrow: Dried, boiled Peraphyllum ramosissimum-Squaw apple: Raw, jelly Persea americana-Avocado: Raw, when ripe

Persea borbonia-Redbay, sweetbay: Raw, but not good Phorodendron serotinum-Mistletoe: Poisonous, see pp. 76-77

Photinia spp.-Christmas berry: Unknown

Phyllanthus acidus - Otaheite gooseberry: Pies, preserves Physulis spp.-Ground cherry, husk tomato: Jelly if ripe, see pp. 116-117

Phytolacca spp.-Pokeberry: Pies if ripe, see pp. 50-54

Podophyllum peltatum-Mayapple, mandrake: Raw, jelly if ripe, see pp. $47-48$

Polygonatum spp.-Soloman's seal: Caution!

Pometia pinnata-Langsir: Roasted

Poncirus trifoliata-Trifoliate orange: Not good, sour

Pontederia cordata-Pickerelweed, pikeweed: Raw, boiled, dried

Prunus spp.-Cherry, plum, peach: Pulp only, see pp. 60-61 Psidium guajava—Guava: Raw, jelly, paste

Punica granatum-Pomegranate: Raw, drink

Pyracantha spp.-Pyracantha, firethorn: Raw, but not good Pyrularia pubera-Buffalo nut: Caution!

Pyrus spp.-Pear: Raw, jelly

Reynosia septentrionalis_-Darling plum: Raw or cooked Rhacoma spp.-Rhacoma, Christmas berry: Raw Rhamnus spp.-Buckthorn, cascara: Caution! see p. 75 Rhodomyrtus spp.-Downy myrtle, finger cherry: Caution! see p. 73

Rhus spp. (not Toxicodendron)—Sumac: Tea

Ribes spp.-Currant, gooseberry: Raw, jelly

Rivina humilis-Rouge plant: Caution!

Rosa spp.--Rose, rose hip: Raw, jelly

Roystonea spp.-Royal palm: Raw, when ripe

Rubus spp.-Thimbleberry, juneberry, loganberry, blackberry, boysenberry, raspberry, dewberry, nagoonberry, cloudberry, salmonberry, wineberry: Raw, jelly, pies, wine 
Sabal palmetto_-Cabbage palm, palmetto palm: Raw, syrup -when ripe

Sambucus spp.-Elderberry: Raw, wine, jelly-only when ripe, see pp. 110-111

Sapindus spp.--Soapberry: Caution!

Sassafras albidum-Sassafras: Not good

Schinus terebinthifolius - Christmas berry: Caution!

Serenoa repens-Saw palmetto: Not good

Shepherdia spp.-Soapberry, buffalo berry, bullberry: Raw. jelly, drink

Sideroxylon foetidissimum-False mastic, jungle plum: Raw, but acid and bitter

Smilacina racemosa-False Solomon's seal, scurvyberry:

Smilacina racemosa-False Solomon's seal, scurvyberr: Caution!

Smilax spp.-Smilax, greenbrier, carrion flower: Raw

Solanum spp.-Nightshade: Poisonous, see pp. 117-120

Sorbus spp.-Mountain ash: Raw, when fully ripe

Spondias spp.-Hogplum, wi tree, vi apple: Raw, preserves

Streptopus spp.-Twisted stalk, Mandarin, liverberry, scootberry, wild cucumber: Caution!

Strychnos nux-vomica-Strychnine: Poisonous, see p. 102

Symphoricarpos spp.-Snowberry, waxberry: Caution!

Symplocos tinctoria-Sweetleaf, horsesugar: Not good

Taxus spp.-Yew, ground hemlock: Raw aril; seed poisonous, see pp. 34-35

Thevetia peruviana-Tiger apple: Poisonous, see pp. 108 109

Torreya spp.-Torreya, stinking cedar: Caution!

Toxicodendron spp.-Poison ivy, oak, and sumac: Poisonous, see pp. $18-22$

Trillium spp.-Trillium, wake-robin: Unknown

Triosteum spp.-Wild coffee, feverwort, tinker's weed, horse gentian: Dried, roasted, drink

Umbellularia californica-California laurel, California bay: Raw, roasted

Vaccinium spp.-Blueberry, cranberry, sparkleberry: Raw, jelly, pies 
Vihurnum spp.-Hobblebush, haw, wild raisin, arrowwood, nannyberry, squashberry: Raw, jelly, pies

Vitis spp.-Grape: Raw, jelly, wine

Waldsteinia fragarioides-Barren strawberry: Raw, but not good

Washingtonia filifera-Washington palm, fan palm: Raw, roasted

Wikstroemia spp.-Akia: Caution!

Ximenia americana-Tallowwood plum, hog plum: Raw, but caution!

Zamia spp.-Coontie, Florida arrowroot: Poisonous, see p. 34

Zizyphus jujuba-Jujube: Raw, dried, candied, jam

Zizyphus mauritiana-Indian jujube: Jelly, preserves 


\section{POISONING OF PETS}

Questions concerning the poisoning of pets are so frequent that the subject should be mentioned briefly. With the animal population exploding just as is the human population, it is not surprising that poisoning of pets is increasing and often presents a serious and complex diagnostic and therapeutic problem for the veterinarian. Coupled with the increased numbers of pets and adding to the potential poisonings is the greater use of exotic plants in and around the home, some of which are poisonous to humans and pets alike.

The great majority of poisoning in pets results from their taking the toxic material in food and water, although occasionally poisoning may result from absorption through a wound or even the unbroken skin. Malicious poisoning is most frequently carried out against dogs and cats, although livestock are sometimes involved. The use of various chemicals to control rabbits, foxes, rats, mice, etc. is common practice, and domesticated animals can be poisoned easily by this bait or even by eating the sick or dead vermin that have eaten the poison. Accidental poisoning may also occur from various substances carelessly left out and available for pets as well as children: chemical dips, dusts and sprays, kerosene, fumigants, soil sterilants, fertilizers, fungicides, herbicides, expended clay pigeons, discarded storage batteries, and many others.

Poisoning of pets by native and cultivated plants is often overlooked and usually dismissed by many people since dogs and cats are primarily meat-eaters. This is a mistake, for while it is true that approximately 90 per cent of their diet 
is meat, the remaining 10 per cent can be almost anything, including poisonous plants. If eaten in sufficient quantity, most plants poisonous to humans and livestock will also be toxic to dogs and cats and other pets. Cases of such poisoning are fairly common.

Pet birds such as canaries have been poisoned by various fruits or seeds of native and cultivated plants around the home. Dogs have been poisoned by mushrooms, fruits such as balsam pear and nightshade, and bulbs of hyacinth and narcissus. Cats have been poisoned by eating English ivy, and the increased popularity of philodendrons in the home has caused a parallel increase in serious illnesses and numerous deaths among cats by this plant.

Proper care of pets should include a realization of the potential poisoning by plants around the home. 


\section{GLOSSARY}

ACHENE: A small dry indehiscent one-seeded fruit.

ALTERNATE: Leaf arrangement when only one leaf is at any one level on the stem (Figure 52).

ANNUAL: A plant completing its entire life cycle in one growing season and dying back in the winter.

ANTHER: Pollen sac, on the stamen of a flower (Figure 55).

ARIL: A fleshy or pulpy outer covering of a seed, or an appendage of a seed.

AXIL: The upper angle that a leaf stalk or petiole makes with the stem that bears it.

BERRY: A type of fruit which is usually more or less fleshy throughout.

BIENNIAL: A plant which requires two years to complete its life cycle. The first year's growth is generally vegetative only.

BLADE: The broad and flattened portion of a leaf (Figure 53).

BRACT: A much-reduced leaf, the small scalelike leaves associated with the flowers, or a highly modified leaf associated with flower clusters.

CALYX: A collective term for the sepals of a flower (Figure 55).

CAP: The expanded top of a mushroom (Figure 51). CAPSULE: A type of fruit which is dry, splits along two or more lines, and has more than one row of seeds.

COMA: A condition of insensibility.

CONVULSION: A violent uncontrolled series of muscular contractions. 
COROLLA: A collective term for the petals of a flower (Figure 55).

DELIRIUM: A state of frenzied excitement.

DIARRHEA: Abnormal and frequent discharge of liquid stools from the intestines.

DILATION OF PUPILS: Enlargement of the pupils in the eyes.

DRUPE: A fruit type with a fleshy outside and a stony pit enclosing the seed.

EMETIC: A chemical or substance that causes vomiting, such as syrup of ipecac, a strong solution of table salt, a strong solution of prepared mustard, or strong soapy water.

FOLLICLE: A type of fruit which is dry and opens along only one side.

GILLS: Platelike structures on the bottom of the cap, bearing spores in a mushroom (Figure 51).

GLABROUS: Not hairy.

GLOBOSE: Round or nearly so in general form; spherical.

INFLORESCENCE: The arrangement or grouping of flowers in a branch system (Figure 55).

LANCEOLATE: Narrow, with widest point near the base and tapering to the apex (Figure 54).

LEAFLET: The bladelike portion of a divided (compound) leaf (Figure 52).

LEGUME: Practically any dry fruit splitting along two lines and having one row of seeds. The fruit type of the bean family.

NARCOTIC: A drug which in moderate doses causes insensibility and relieves pain; in larger doses produces stupor and convulsions.

NAUSEA: Uneasiness of the stomach with a desire to vomit.

NODE: Position on a stem where a leaf is attached (Figure 52),

OPPOSITE: Two leaves, opposing each other, at any one level on a stem; two leaves at a node (Figure 52).

OVARY (of flower): Lower portion of pistil, contains the ovules (Figure 55).

OVATE: Relatively wide and broadest near the base (Figure 54). 
OVOID: Egg-shaped, with the greatest diameter near the base.

OVULE: Structure in ovary which contains the egg and which develops into the seed after fertilization of the egg.

PALMATE: Radiating from a common point: palmately veined (Figure 52) or palmately divided leaf (Figure 53).

PANICLE: A rather broad and often many-branched inflorescence (Figure 55).

PERENNIAL: Plants that continue to live year after year.

PERIANTH: Collective term for the sepals and petals of a flower (Figure 55).

PETAL: One unit of the inner whorl of sterile leaflike parts of a flower; usually colored and showy (Figure 55).

PETIOLE: The stalk of a leaf.

PINNATE: Arranged along a central axis; pinnately veined (Figure 52) or pinnately divided leaf (Figure 53).

PISTIL: The central structure(s) of a flower which develops into the fruit after fertilization (Figure 55).

PITH: The soft spongy central cylinder of most stems (Figure 52).

POLLEN: Minute granular structures produced in the anthers of the flower (Figure 55) and necessary for sexual reproduction in seed plants.

POME: A fleshy fruit with a fleshy outer portion and a papery "core"; an apple is a pome.

RACEME: A rather elongated and slender inflorescence in which the pedicels are attached to a simple central axis and are unbranched (Figure 55).

RESPIRATORY: Pertaining to the lungs and other organs for breathing.

RHIZOME: An underground stem, often horizontal.

RING: A thin, loose tissue around the stalk of a mushroom; often called the veil or annulus (Figure 51).

ROOTSTOCK: A rhizome or the perennial source of stems and roots; or used as a general term for any root system.

SALIVATION: An excessive discharge of saliva from the mouth.

SEED: A ripened ovule after fertilization of the egg; 
embryonic plant within a protective coat, which will germinate into a new plant.

SEPAL: One unit of the outer whorl of sterile leaflike parts of a flower; often green but sometimes colored (Figure 55).

SIMPLE: A leaf blade which is not divided into leaflets (Figure 53).

SPASM: An uncontrolled and unnatural muscular contraction.

SPIKE: An inflorescence which is generally long, slender and with sessile flowers (Figure 55).

SPORE: A minute structure, not a seed, which is capable of developing into a new individual; a reproductive body in non-seed plants.

STALK: Stemlike structure at the base of a flower or leaf (used here in place of pedicel, peduncle, petiole) (Figure 53).

STAMEN: The part of the flower in which the pollen is produced; the pollen-bearing organ of a flower composed of anther (pollen sac) and filament (stalk) (Figure 55). STIPULE: One or two small bracts or leaves at the base of a leaf (Figure 53).

STUPOR: Partial or complete unconsciousness.

TREMOR: An involuntary trembling, shivering, or shaking. TUBER: Swollen and fleshy underground stem (as a potato). UMBEL: A branched flat-topped cluster of small flowers (Figure 55).

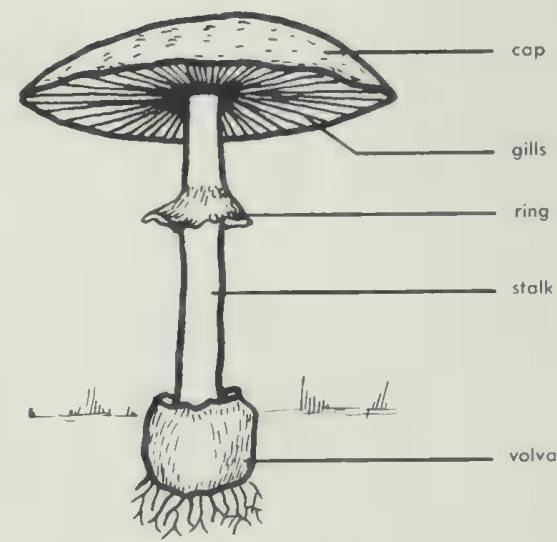

Figure 51. Parts of a mushroom. 
VOLVA: Swollen cup at base of some mushrooms (Figure $51)$.

WHORLED: Three or more leaves at a node (Figure 52).
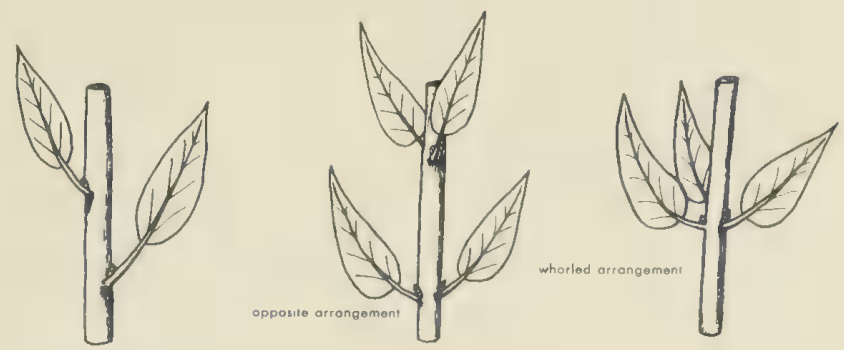

alternate arrangemen
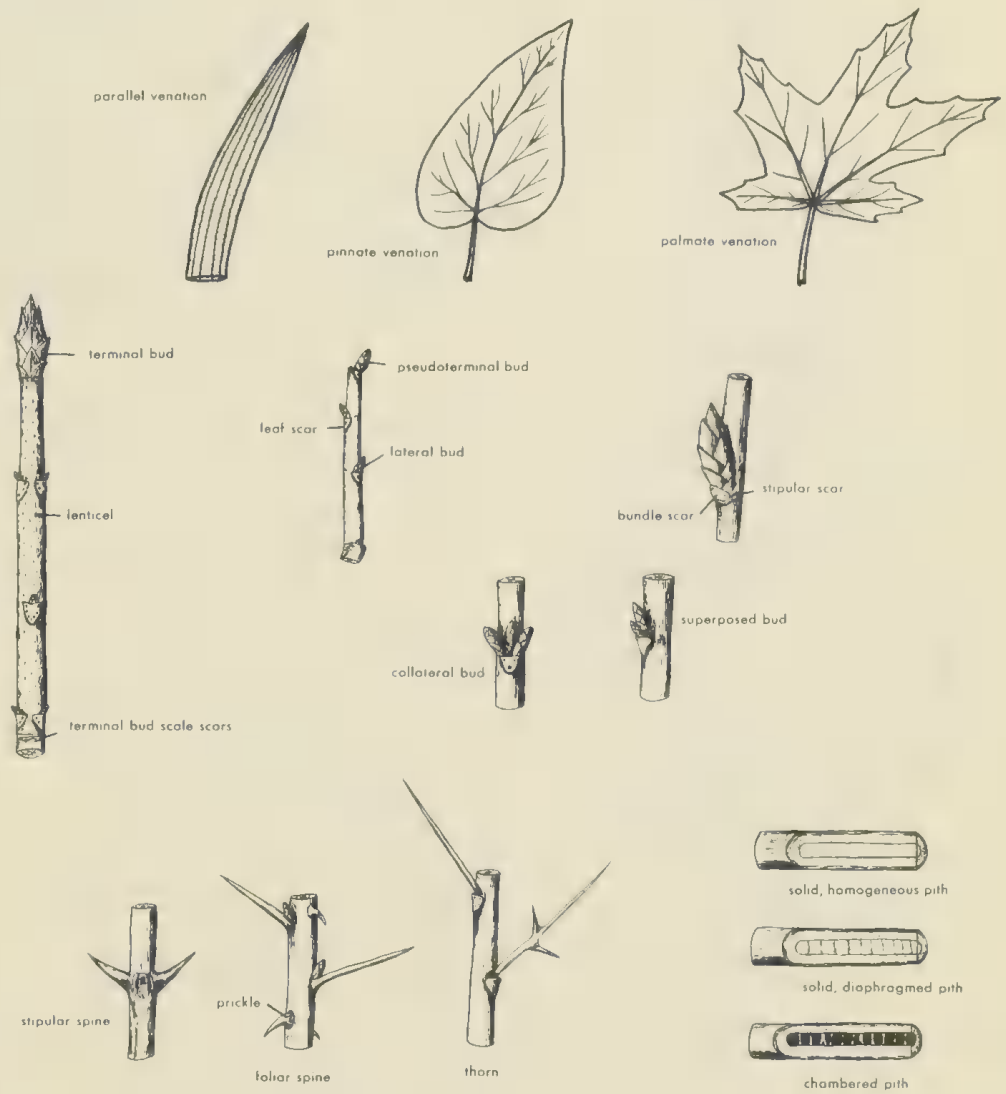

Figure 52. Twigs and leaves. 

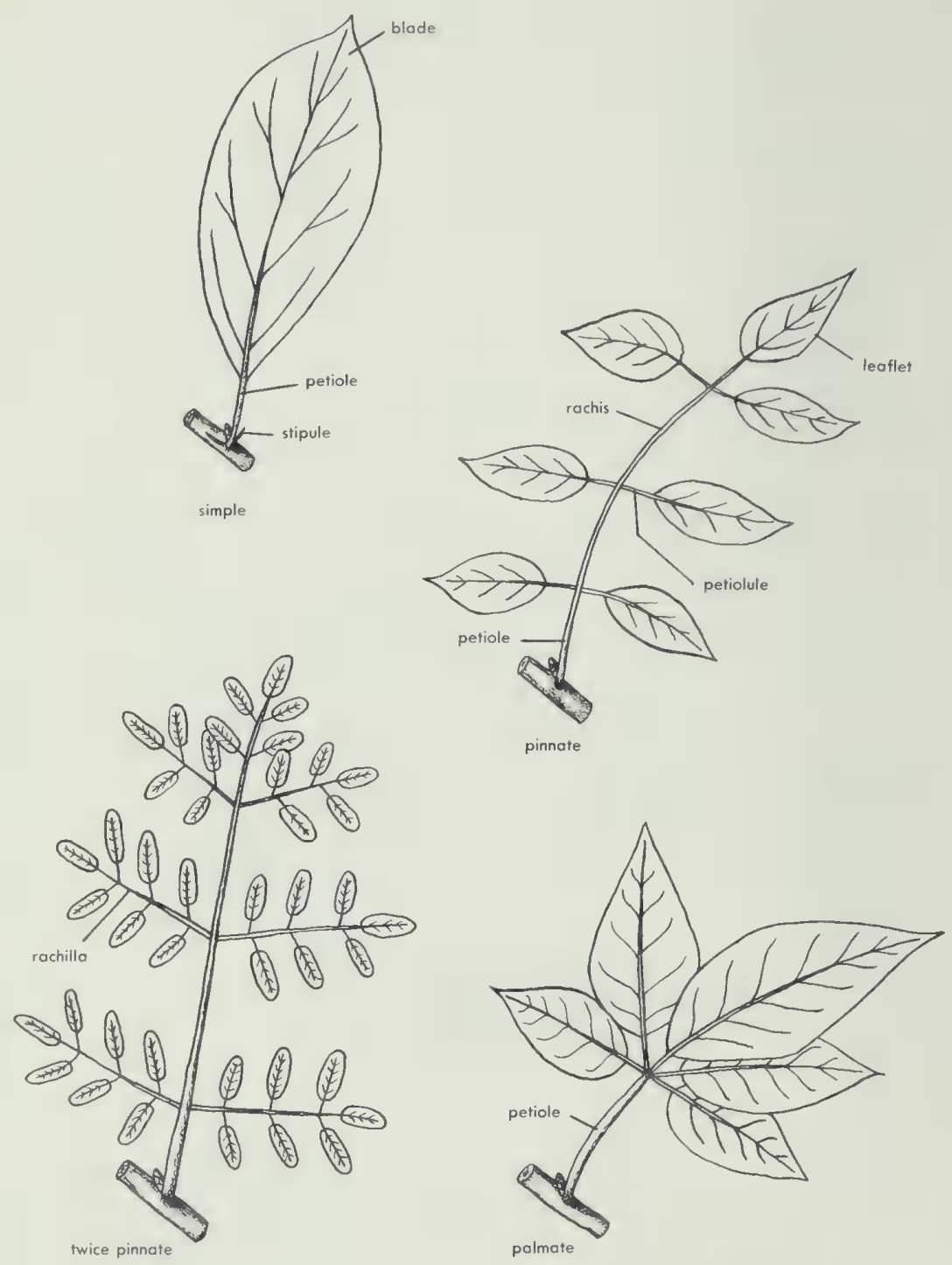

Figure 53. Leaf forms. 

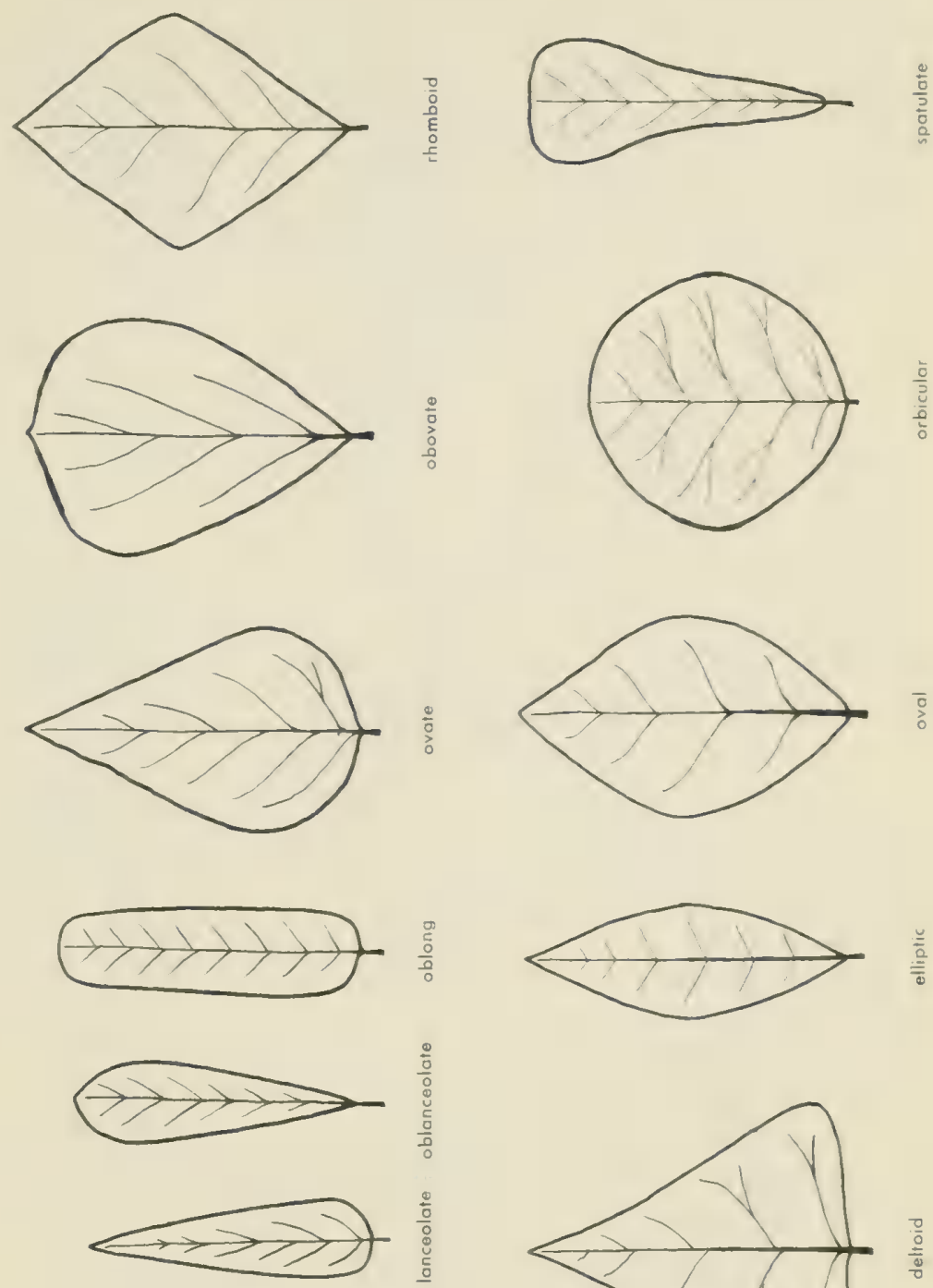

$\leftrightarrow \rightarrow \rightarrow \rightarrow \longrightarrow \rightarrow \longrightarrow$ :

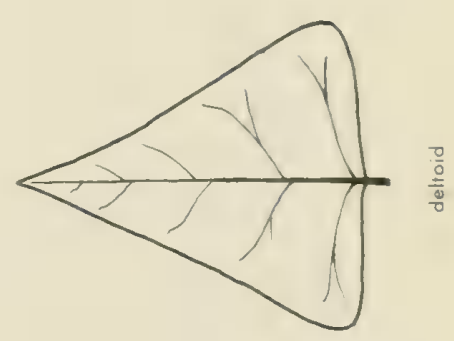

Figure 54. Leaf shapes. 

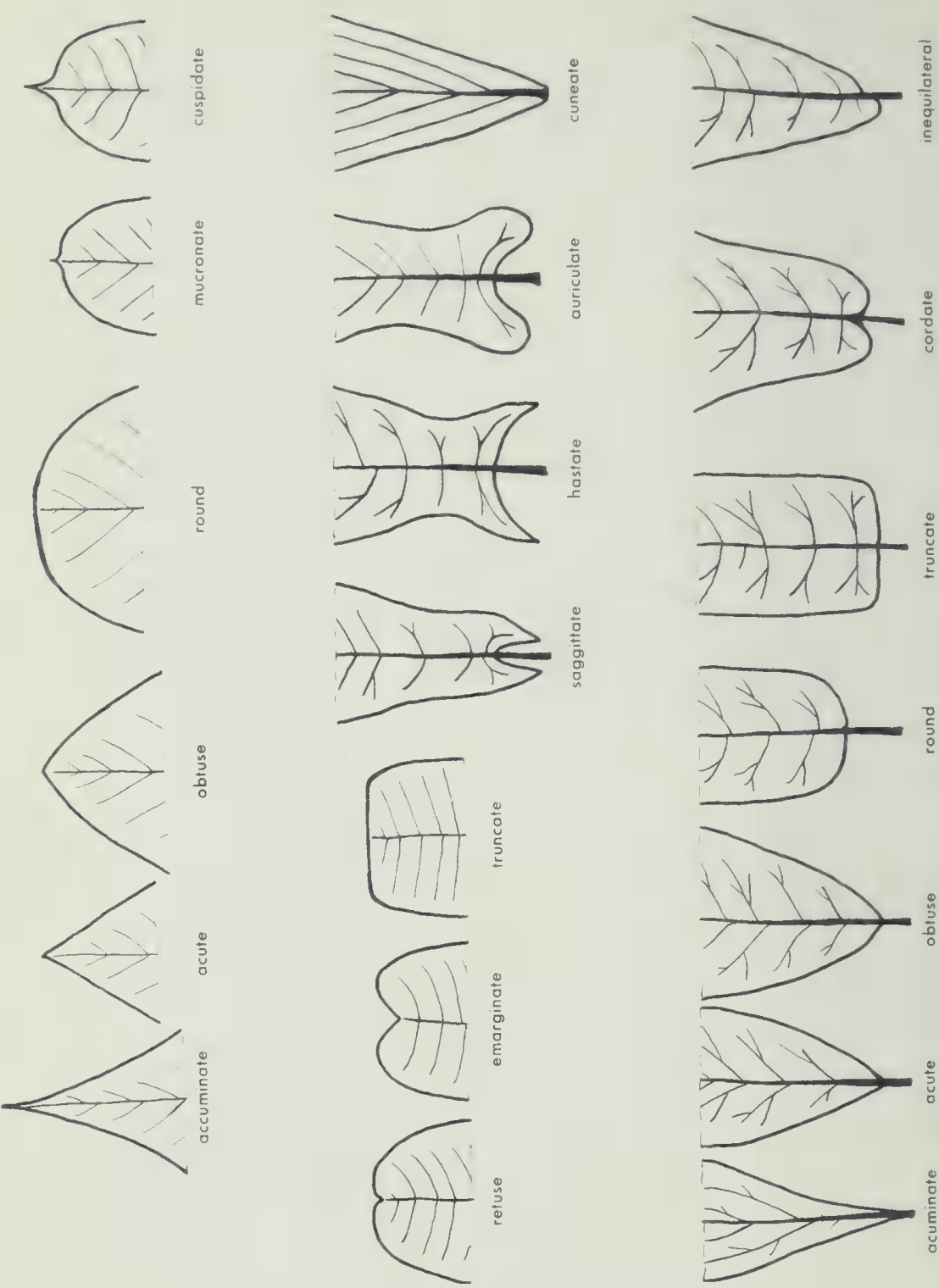

Figure 54. Leaf shapes.

\section{Glossary}




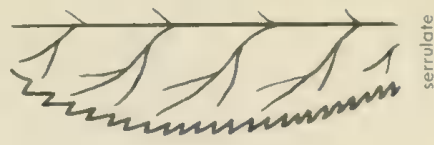

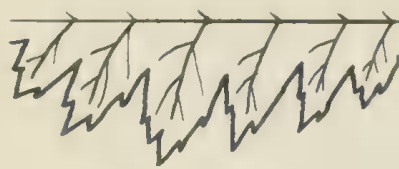

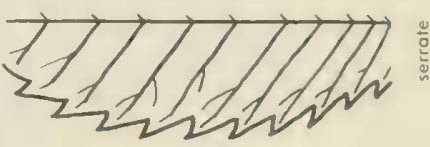

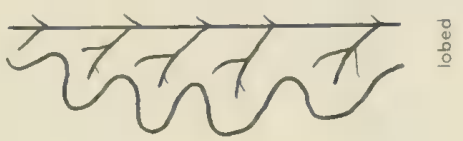

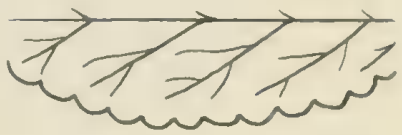

गे
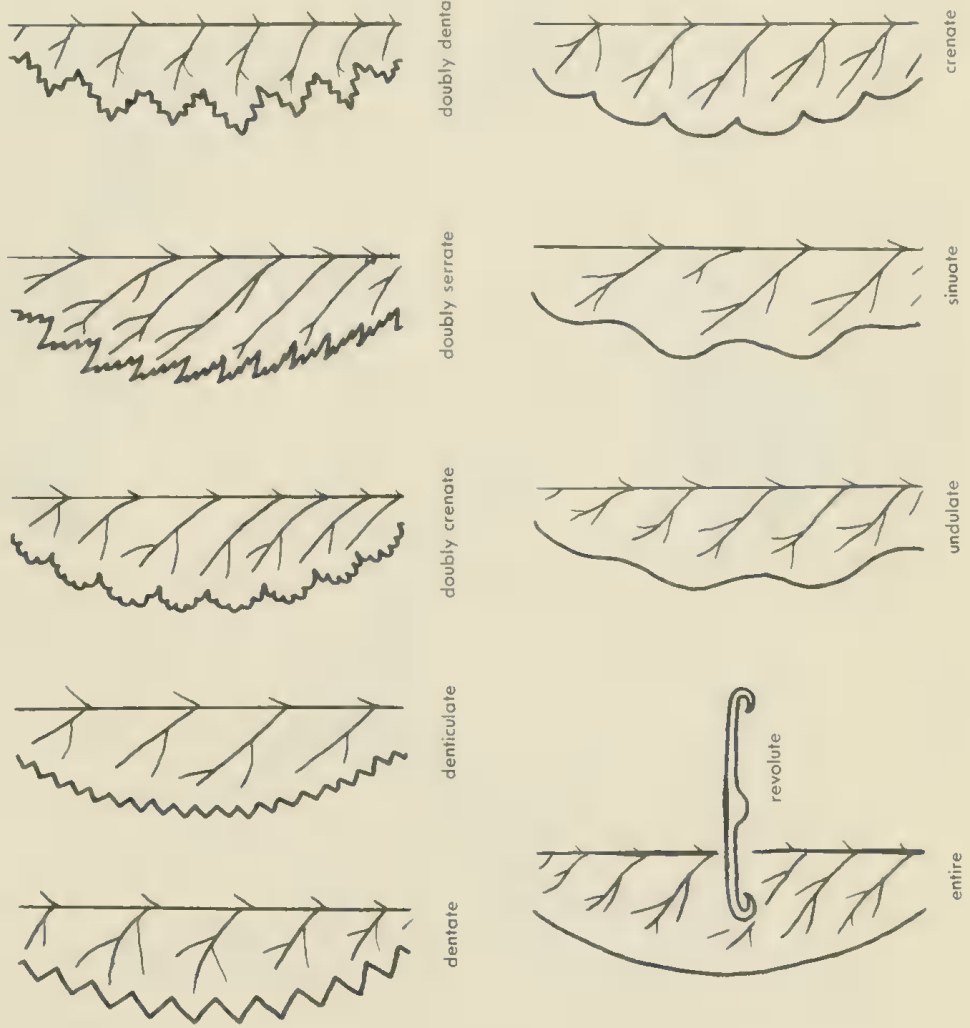

Figure 54. Leaf shapes. 

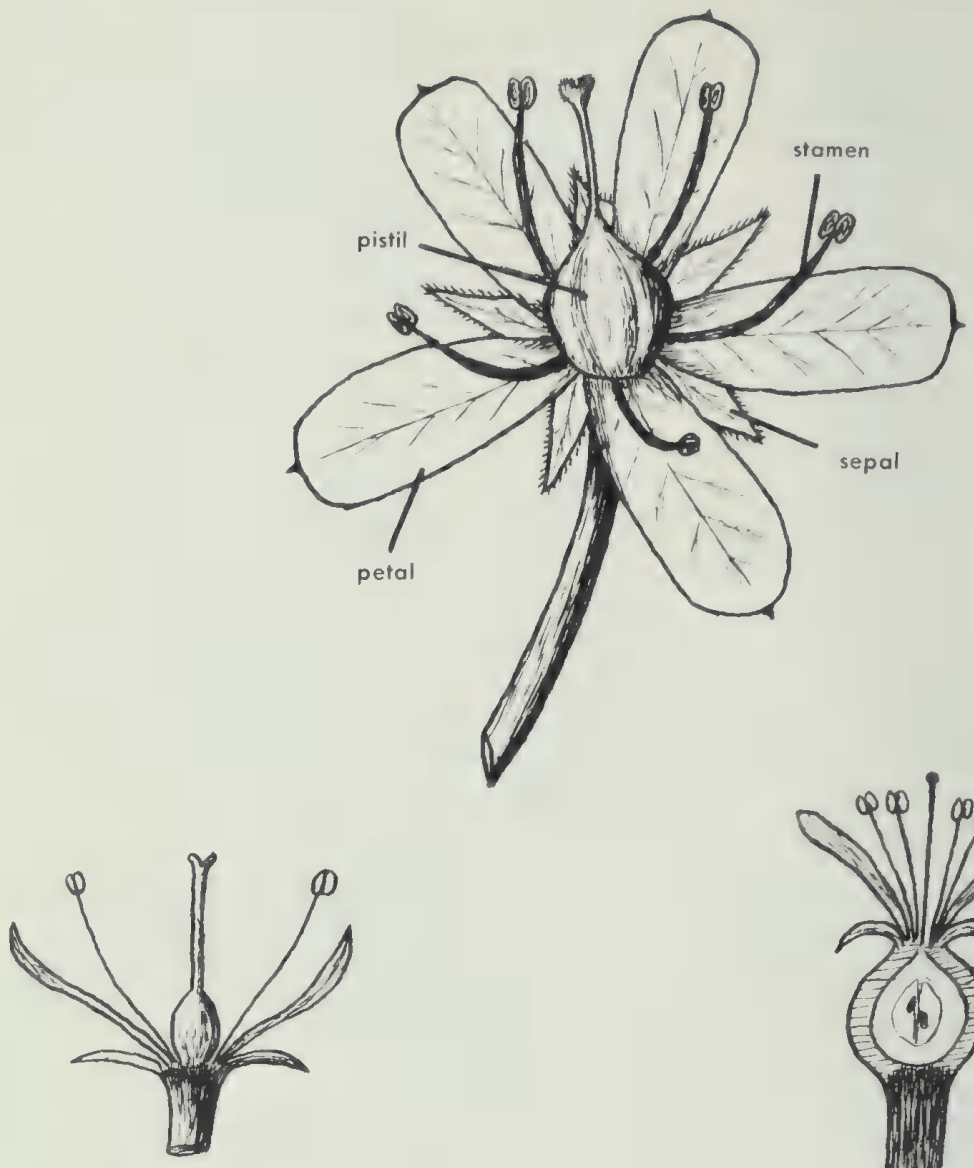

hypogynous
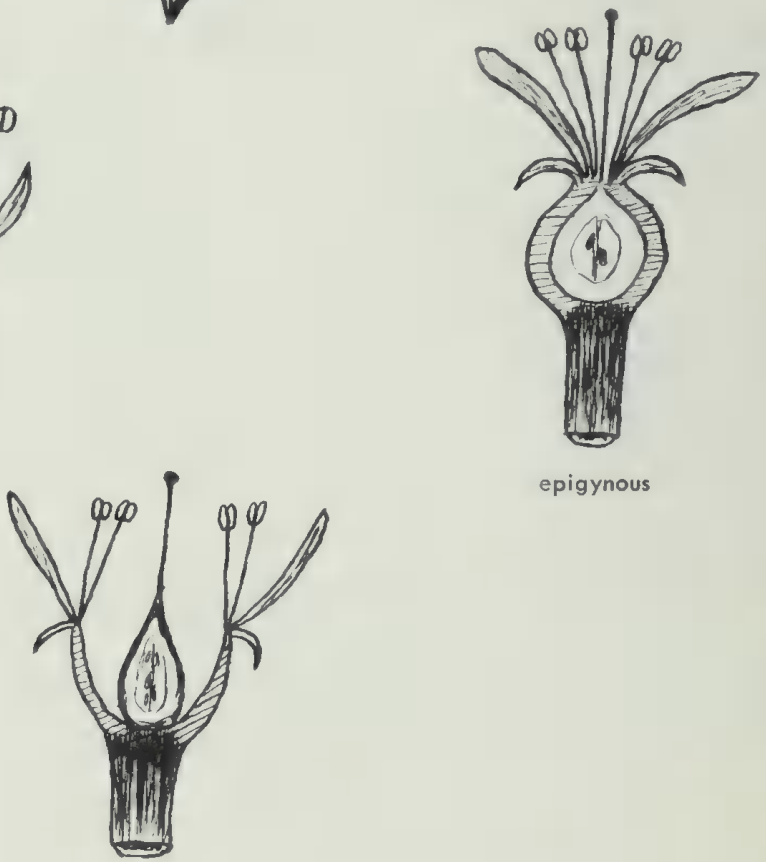

epigynous

perigynous

Figure 55. Flower parts and inflorescences. 


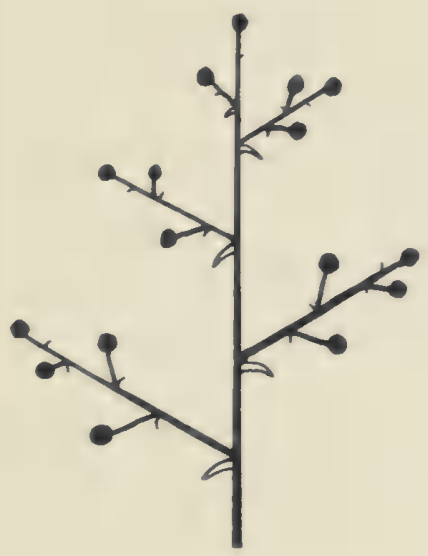

panicle

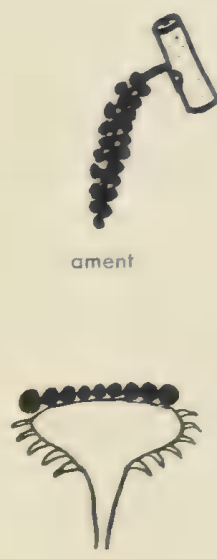

head

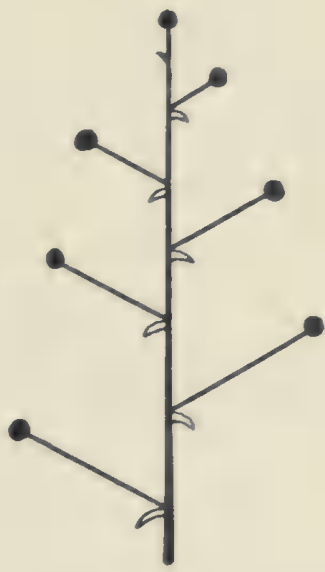

raceme

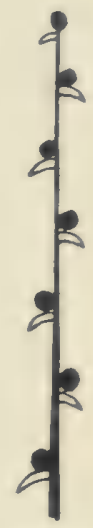

spike

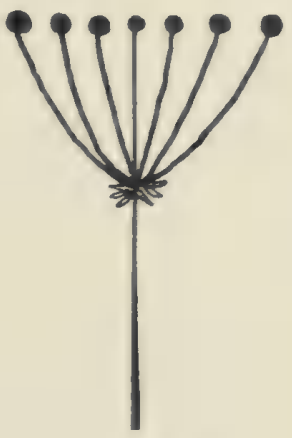

umbel

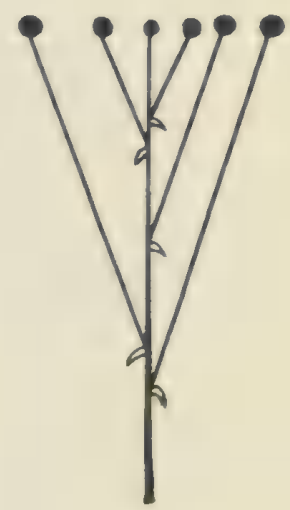

corymb 


\section{BIBLIO(;RAPHY}

\section{GENERAL REFERENCES}

Arena, Jay M. Poisoning: Chemistry, Symptoms, Treatments. Springfield, Ill.: Charles C. Thomas, 1963. Baskin, Esther. The Poppy and Other Deadly Plants. New York: Delacorte Press, 1967.

Deichmann, W. B., and H. W. Gerarde. Symptomatology and Therapy of Toxicological Emergencies. New York: Academic Press, 1964.

Duncan, Wilbur H. Poisonous Plants in the Southeastern United States. Athens, Ga: the author, 1958.

Fernald, M. L., and A. C. Kinsey. Edible Wild Plants of Eastern North America (revised by R. C. Rollins). New York: Harper and Row, 1958.

Gillespie, W. H. Edible Wild Plants of West Virginia.

New York: Scholar's Library, 1959.

Hardin, James W. Commercial Herbs, Roots and Pollens of North Carolina. North Carolina Agricultural Experiment Station Bulletin 435, 1968.

Harrington, H. D. Edible Native Plants of the Rocky Mountains. Albuquerque: University of New Mexico Press, 1967.

Harvey, R. B., et al. Pesky Plants. University of Minnesota Agricultural Experiment Station Bulletin 381, 1944. Hesler, L. R. Mushrooms of the Great Smokies. Knoxville: University of Tennessee Press, 1960.

Hood, Mary V. Outdoor Hazards, Real and Fancied. New York: Macmillan, 1955. 
Kingsbury, John M. Poisonous Plants of the United States and Canada. Englewood Cliffs, N.J.: PrenticeHall, 1964.

Deadly Harvest: A Guide to Common Poisonous Plants. New York: Holt, Rinehart and Winston, 1965. Lampe, Kenneth F., and Rune Fagerström. Plant Toxicity and Dermatitis: A Manual for Physicians. Baltimore: Williams and Wilkins, 1968.

Marderosian, Ara Der. "Poisonous Plants in and around the Home," American Journal of Pharmaceutical Education, XXX (1966), 115-140.

Modell, Walter, and Alfred Lansing. Drugs. Morristown, N.J.: Silver Burdett, 1967.

Morton, Julia F. "Ornamental Plants with Poisonous Properties," Proceedings of the Florida State Horticultural Society, LXXI (1958), 372-380; LXXV (1962), 484-491.

Wild Plants for Survival in South Florida. Miami: Hurricane House, 1962.

Phillips Petroleum Company. Pasture and Range Plants, Sec. IV: Poisonous Grassland Plants. Bartlesville, Okla.: Phillips Petroleum, 1957.

Ramsbottom, J. Poisonous Fungi. New York: Penguin Books, 1945.

Sievers, A. F. American Medicinal Plants of Commercial Importance. USDA Miscellaneous Publication 77. 1930.

West, Erdman. Poisonous Plants Around the Home. Florida

Agricultural Experiment Station Circular S-100, 1957 Wolfe, H. S. Miscellaneous Tropical and Sub-tropical Florida Fruits. Florida and USDA Cooperative Extension Bulletin 109, 1941.

Wyeth Laboratories. The Sinister Garden: A Guide to the Most Common Poisonous Plants. New York: Wyeth Laboratories, 1966. 


\section{POISONOUS PLANT MANUALS, BY STATE AND CANADA}

Alabama

Cory, C. A., et al. Poisonous Plants of Alabama. Alabama Polytechnic Institute Extension Circular $71,1924$.

Alaska

Heller, Christine A. Wild Edible and Poisonous Plants of Alaska. University of Alaska and USDA Cooperative Extension Service Bulletin F-40, 1953.

California

Sampson, A. W., and H. E. Malmsten. Stock-poisoning Plants of California. California Agricultural Experiment Station Bulletin 593, 1942.

Canada

Fyles, F. Principal Poisonous Plants of Canada. Canada Department of Agriculture, Dominion Experimental Farms Bulletin 39 (2nd ser.), 1920.

McLean, A., and H. H. Nicholson. Stock Poisoning Plants of the British Columbia Ranges. Canada Department of Agriculture Publication 1037, 1958. Colorado

Durrell, L. W., et al. Poisonous and Injurious Plants in Colorado. Colorado Agricultural Experiment Station Bulletin 412-A, 1952.

Connecticut

Shepard, C. E., E. M. Bailey, and D. C. Welden. Notes on Livestock Poisoning in Connecticut. Connecticut Agricultural Experiment Station Bulletin $470,1943$.

Florida

Maxwell, Lewis S. Florida's Poisonous Plants, Snakes, Insects. Tampa: L. S. Maxwell, 1963.

West, Erdman, and M. W. Emmel. Poisonous Plants in Florida. Florida Agricultural Experiment Station Bulletin 510, 1952.

Georgia

Duncan, W. H., and T. J. Jones. Poisonous Plants 
of Georgia. University of Georgia School of VeteriHawaii

nary Medicine Bulletin XLIX, No. 13, 1949.

Arnold, Harry L. Poisonous Plants of Hawaii. Rutland, Vt.: Charles E. Tuttle, 1968.

Idaho

Gail, Floyd W. Some Poisonous Plants of Idaho. University of Idaho Agricultural Experiment Station Bulletin 86, 1916.

Illinois

Tehon, L. R., C. C. Morril, and R. Graham. Illinois Plants Poisonous to Livestock. Illinois Extension Service Circular 599, 1946.

Indiana

Hansen, A. A. Indiana Plants Injurious to Livestock. Purdue Agricultural Experiment Station Circular 175, 1930.

Lee, O. C., and L. P. Doyle. Indiana Plants Poisonous and Injurious to Livestock. Purdue Agricultural Extension Service Bulletin 240, 1950.

Kansas

Choguill, H. S. Some Poisonous Plants of Kansas.

Kansas Academy of Science Transactions 61(1), 1958. Kentucky

Hyatt, M. T., R. G. Brown, and J. W. Herron. Some Plants of Kentucky Poisonous to Livestock. Kentucky Agricultural Extension Service Circular 502, 1953. Louisiana

Gowanloch, J. N., and C. A. Brown. Poisonous Snakes, Plants and Black Widow Spider of Louisiana. New Orleans: Louisiana Department of Conservation, 1943.

Maryland

Brown, R. G. Plants Poisonous to Livestock. Maryland Agricultural Extension Service Fact Sheet 91, 1955. Reynard, G. B., and J. B. S. Norton. Poisonous Plants of Maryland in Relation to Livestock. Maryland Agricultural Experiment Station Bulletin A-10, 1942. 
Minnesota

Harvey, R. B., et al. Weeds Poisomous to Livestock.

Minnesota Agricultural Experiment Station Bulletin $388,1945$.

Mississippi

Therell, J. S., and W. R. Thompson. Poisonous Trees, Bushes and Stumps. Mississippi Agricultural Extension Service Agronomy Folder 10, 1949.

Montana

Welch, H., and H. E. Morris. Range Plants Poisonous (o) Livestock in Montana. Montana Agricultural Experiment Station Circular 197, 1952.

New Mexico

Hershey, A. L. Some Poisonous Plant Problems of New Mexico. New Mexico Agricultural Experiment Station Bulletin 322, 1945.

Norris, J. J., and K. A. Valentine. Principal Poisonous Plants of New Mexico Ranges. New Mexico Agricultural Experiment Station Bulletin 390, 1954.

New York

Muenscher, W. C., and W. T. Winne. Common Poisonous Plants. Cornell Agricultural Extension Service Bulletin 538, 1955.

North Carolina

Hardin, James W. Poisonous Plants of North Carolina.

North Carolina Agricultural Experiment Station Bulletin 414,1961 .

Stock-poisoning Plants of North Carolina.

North Carolina Agricultural Experiment Station Bulletin 414 (revised), 1966.

North Dakota

Stevens, O. A. Poisonous Plants and Plant Products. North Dakota Agricultural Experiment Station Bulletin 265, 1933.

Ohio

Schaffner, J. H. "Poisonous and Other Injurious Plants of Ohio," Ohio Naturalist, IV (1903), 32.

Oklahoma

Featherly, H. I. Some Plants Poisonous to Livestock 
in Oklahoma. Oklahoma Agricultural Experiment Station Circular C-118, 1945.

Oregon

Gilkey, H. M. Livestock-Poisoning Weeds of Oregon. Oregon Agricultural Experiment Station Bulletin $564,1958$.

Pennsylvania

Graham, E. H. Poisonous Plants of Pennsylvania. Pittsburgh: Carnegic Museum, 1935.

Gress, E. M. Poisonous Plants of Pennsylvania. Pennsylvania Department of Agriculture Bulletin 18(5), No. 531, 1935.

Texas

Walker, A. H. Poisonous Range Plants of Texas. Texas Agricultural Extension Service Leaflet 114, 1949. Sperry, O. E., et al. Texas Range Plants Poisonoms to

Livestock. Texas Agricultural Experiment Station Bulletin 796, 1955.

Utah

Stoddart, L. A., et al. Important Poisonnous Plants of Utah. Utah Agricultural Experiment Station Special Report 2. 1949.

Virginia

Massey, A. B. Poisonous Plamts. Virginia Polytechnic Institute Extension Service Bulletin 222, 1954.

West Virginia

Core, Earl L.. et al. The Poisonous Plants of West Virginia. Charleston: West Virginia Department of Agriculture, 1961.

Wyoming

Beath, O. A., et al. Poisonous Plants and Livestock Poisoning. Wyoming Agricultural Experiment Station Bulletin 324, 1953. 


\section{INDEX TO SCIENTIFIC AND COMMON NAMES}

Abrus precatorias, 62

Achrus, 127

Aconite, 44

Aconilum, 44

columbianum, 44

nepellus, 44

reclinatum, 44

uncinatum, 44

Actaca, 44, 127

alba, 45

arguta, 45

pachvpoda, 45

rubra, 45

Adonis, spring, 46

Adonis vernalis, 46

Aesculus, 79

californica, 79

glabra, 79

hippocastanum, 79

octandra. 79

parryi, 79

parviflora, 79

pavia, 80

sylvatica, 80

Agave, 12

Agrostemma githago, 54, 55

Ailanthus altissima, 12

Akebia, 127

Akebia quinata, 127

Akee, 78,128

Akia, 134

Alder, 9

Aleurites, 127

fordii, 89

moluccana, 90

Algae, 9, 28

Allamanda, pink, 109

purple. 109

wild, 109

yellow, 12, 103, 104

Allamanda cathartica, 12, 103. 104

Almond, 60

Alocasia, 42

Alsike clover, 15
Amanita, Browning, 31

Amanita, 31

brunnescens, 31

vernat, 30

Amaryllidaceae, 39

Amaryllis, 39

A maryllis family, 39

Ambrosia artemisiifolia, 10, 12

Amelanchier, 127

American beech, 72

Ampelopsis, 127

Anacardium occidentale, 12, 127

Anagallis arvensis, 12

Anemone', 46

Angel's trumpet, 114, 115

Annona, 127

Anthemis cotula, 12

Anthurium, 42

Apiaceae, 84

Apocynaceae, 103

Apocynum cannabinum, 104, 105

Apple, 60, 131

cashew, 127

crab, 60, 131

custard, 127

dog, 128

gopher, 129

horse. 14

kei, 129

mammee, 131

may, 47, 132

pitch, 129

pond, 127

prickly, 130

seven-year, 128

squaw, 131

star, 129

thorn, 48, 112, 113

tiger, 108, 133

vi, 133

wild balsam. 88

Apple cactus, 130

Apple-of-Peru, 116, 131

Apple of Sodom, 120

Aquifoliaceae, 74 
Araceae, 40

Aralia, 127

spinosu, 12,83

Araliaceae, 83

Arctostaphylos, 127

Ardisia escallonioides, 127

Areca calechu, 42, 128

Areca nut, 42

Arecaceae, 42

Arecastrum romanzoffianum, 128

Argemone mexicana, 48

Arisaema triphyllum, 12, 41, 128

Arnica montana, 124

Arnica root. 124

Aronia, 128

Arrow, green, 131

Arrow arum, 131

Arrowroot, Florida, 34, 134

Arrowwood. 133

Artabotn's uncinatus, 128

Artocurpos, 128

Arum, arrow, 131

Arum family, 40

Asarum cancidense, 13

Asclepiadaceac, 109

Asclepias, 109

Ash, 9

mountain, 133

poison, 20,21

Asimina, 128

triloba, 13

Asparagus, 13, 128

Asparagus officinalis, 13,128

Aster family, 124

Asteracese, 124

Atropa belladonna, 111, 128

Autumn crocus, 35

Averrhoa carambola, 128

Avocado, 132

Azalea, 100

Bagpod, 63

Bahama strongbark. 128

Balsam apple, wild, 88

Balsam pear, 88,131

Banana family, 35

Baneberry, 44, 45, 127

western, 45

Barbados cherry, 131

Barbados nut, 94.95

Barberry, 128

Barberry family, 47

Barren strawberry, 134

Bastard toadflax, 129

Bay, California, 133

red, 132

sweet, 132

Bean, broad, 68

castor, 96

curcas, 94, 95

English, 68

fava, 68

horse, 68 hyacinth, 64

love, 62

lucky, 62

mescal, 68

prayer, 62

precatory, 62

Windsor. 68

Bearberry, 127

Beautybush, 128

Beech, 9, 72

American. 72

European, 72

Belamcanda chinensis, 128

Belladonna, 111,128

Bellyache bush, 94

Benzoin. 130

Berberidacese, 47

Berberis. 128

Berchemia scandens, 128

Berry, bane. 44. 45

bear, 127

black. 132

blue. 133

boysen, 132

buffalo, 133

bull, 133

bunch, 129

China, 77, 78, 131

choke, 128

Christmas, 130, 132, 133

cloud, 132

coral, 44,45

crack, 130

crow, 130

curlew, 130

dew. 132

dog, 127

elder, 110,132

goose, 132

hack, 128

ink. 50,52

June, 132

liver, 133

locust, 128

logan, 132

marl. 127

nanny, 133

nagoon, 132

partridge, 131

pigeon, $50,52,121,130$

poison, 113

poke, 50.52

salmon, 132

scoot, 133

scurvy, 133

service, 127

shad, 127

silver, 130

snake, 44,45

snow, 133

soap, 133

sparkle. 133

squash, 133 
sugar, 128

tea, 130

thimble, 132

water, 131

wax, 133

wine, 132

Be-still tree, 108

Betel nut, 42, 128

Birch, 9

Bird-of-paradise, 35, 66

Bird pepper, 13

Bitter gourd, 88

Bittersweet, 128

climbing, 74

European, 1/9, 120

Black cherry, 60, 6I

Black gum, 131

Black haw, 128

Black henbane, 114

Black locust, 66, 67

Black nightshade, 117,118

Black sapote, 129

Black snakeroot, 39

Blackberry, 132

Blackberry lily, 128

Bladderpod, 63

Bleeding heart, 13,50,5l

Blighia sapida, 78, 128

Blite, strawberry, 129

Bloodroot, 15, 49

Blue cohosh, 13,48, 128

Blueberry, 133

Bottlebrush buckeye, 79

Bomreria ovata, 128

Bower, virgin's, 13, 46

Box, 58

Box-thorn. 131

Boxwood, 13, 58

Boxwood family, 58

Boysenberry, 132

Brassicaceac, 88

Brazil nut. 73

Brazilian pepper, 15

Breadfruit, 128

Breeches, Dutchman's, 50

Broad bean, 68

Broccoli. 88

Browning amanita, 31

Brussels sprouts, 88

Buckeye. 79 bottlebrush, 79

California, 79

Ohio, 79

painted, 80

red, 80

yellow, 79

Buckeye family. 79

Buckthorn, 75, 128, 132

Buckthorn family. 75

Buckwheat family, 58

Buffalo berry, 133

Buffalo nut, 132

Bull nettle, 16
Bulliberry, 133

Bumclia, 128

Bunchberry, 129

Burning bush, 23, 74

Burrow weed, 126

Buttercup, 14, 47

Buttercup family, 44

Button, mescal, 56, 57

Buxac'cae', 58

Buxus sempervirens, 13, 58

Byrsonima lacidam, 128

Cabbage, 88

Cabbage palm, 132

Cactuc'use, 56

Cactus, apple, 130

opuntia, 131

tree, 128

Cactus family, 56

Cajeput, 14

Caludium, 42

California bay, 133

California buckeye, 79

California laurel, 133

Calla palustris, 128

Calla, wild, 128

Callicarpa americana, 128

Calocarpam sapota, 128

Calophyllum inophyllum, 128

Calotropis gigantea, 109

Caltha palustris, 46

Caltrop family, 83

Camas, death, 39

Campsis radicans, 13,15

Cananga odorata, 128

Candlenut, 90, 127

Canistel, 131

Cannabaceae, 70

Cannubis sativa, 70, 71

Cannonball tree, 73

Caper spurge, 91

Caprifoliaceae, 110

Copsicum frutescens, 13, 128

Carambola, 128

Cardinal flower, 122

Carica papaya, 13, 128

Carrion flower, 133

Carissa, 128

Carissa grandiflora, 128

Carolina jessamine, 102, 103

Carrot, wild, 13

Carrot family, 84

Caryophyllaceae, 54

Caryota, 128 milis, 13

Casasia clusiaefolia, 128

Cascara, 132

Cashew apple, 127

Cashew nut, 12

Cassava, 94

Castor bean, 96

Castor-oil plant, 96

Catalpa, 13 
Cauliflower, 88

Caulophyllum thalictroides, 13. 48,128

Cedar, 9, 130

red, 14

stinking, 133

Celandine, 13, 49

Celastraceae, 74

Celastrus scandens, 74, 128

Celtis, 128

Century plant. 12

Cephalocereus, 128

Cereus, night-blooming, 130

Ceriman, 131

Cestrum, 113 green, 113

Cestrum, 129 diurnum, 113 nocturnum, 113 parqui, 113

Chain, golden. 65

Chaenomeles, 129

Chalice vine, 117

Chelidonium majus, 13, 49

Chenopodium capitatum, 129

Cherimoya, 127

Cherry, 60, 132

Barbados, 131

black, 60,61

finger, 73, 132

ground, 116, 132

Jerusalem, 116, 120

laurel. 60

Surinam, 130

wild, 60,61

Cherry laurel. 60

Chili pepper. 128

Chimaphila umbellata, 13

Chinaball tree. 77.78

Chinaberry, 77, 78, 131

Chinatree. 77.78

Chinese lantern, 116

Chionanthus virginicus, 129

Chokeberry, 128

Christmas berry. 130. 132. 133

Christmas rose, 46

Chrvanthemum, 13

Chrysobalanus, 129

Chrvsophyllum, 129

Cicuta maculata, 84

Citharexylum fruticosum, 129

Cissus, 127

Citrus, 129

aurantifolia, 13, 129

aurantium, 129

trifoliatus, 129

Clematis, 46 virginiana, 13

Climbing bittersweet. 74

Climbing lily, 36, 37

Climbing nıghtshade, 1/9, 120

Clintonia, 129

Clintonia borealis, 129
Clitocybe, 31

illudens, 32

Cloudberry. 132

Clover, alsike, 15

Club, Hercules: 12,83, 127

Clusia rosea, 129

Cnidoscolus, 13 stimulosus, 16

Coca, 81

Coca family. 81

Coccoloba, 129

Coccothrinax argentata, 129

Cocculus, 129

Cockle. 54. 55 corn. 54, 55

Coconut palm, 129

Cocoplum, 129

Cocos nucifera, 129

Coffee, wild, 133

Coffee tree, Kentucky, 64

Cohosh. blue. 13, 48, 128 white, 44, 45

Colchicum autumnale, 35

Colocasia, 42

Comandra, 129

Compositae. 124

Conium maculatum, 13,86

Convallaria, 36 majalis, 36

montana, 36

Coontie, 34. 134

Coralberry, 44,45

Coral plant, 94

Coral sumac, 18

Cordia, scarlet, 129

Cordia sebestena, 129

Corn, squirrel, 50

turkey, 50

Corn cockle, 54, 55

Cornus, 129

Cotoneaster, 129

Cowbane, spotted, 84

Cowitch. 13.15

Coyotillo, 75, 130

Crab apple. 60, 131

Crabseye, 62

Crackberry. 130

Cranberry, 133

Crape jasmine, 106

Crataegus, 129

Creeper, trumpet, 13,15 Virginia, 75, 76, 131

Creeping cucumber, 131

Cress, 88

Crinum, 39

Crocus, autumn, 35

Crosier, 34

Crosier cycas. 34

Crowberry. 130

Crowfoot, 47

Crownflower, 109

Crown-of-thorns, 91

Cruciferae, 88 
Cryplostegia, 13, 109 grandiflora, 109 madagascariensis, 13

Cucumber, creeping, 131 Indian, 131 wild, 133

Cucurbilaceae, 88

Curcas bean, 94,95

Curlewberry, 130

Currant, 132

Custard apple, 127

Cycuduceres, 34

Cycad, 34, 129

Cycas, crosier, 34

Cucas, 34 circinalis, 34,129

Cydonia oblongu, 129

Cypress spurge, 90

Cypripedium, 13

Daffodil, 39

Daisy, 13

Daisy fleabane, 13

Daphne, 72, 129

Daphne mezereum, 72, 129

Darling plum, 132

Datura, 112, 113

Datura, 13,112, 113,115

metaloides, 113

metel, 114

stramonium, 13,112, 113

suaveolens, 114,115

Daubentonia punicea, 63

Daucus carota, 13

Day-blooming jessamine, 113

Deadly nightshade, $111,119,120$

Death camas, 39

Delphinium, 46 ajacis, 13

Destroying angel, 30

Devil's trumpet, 114

Devil's walkingstick, 83

Devilwood, 131

Dewberry, 132

Dewdrop, golden, 121

Dicentra, 13, 50,51 eximia, 51

Dictamnus albus, 22

Dieffenhachia, 40 picta, 40 seguine, 40

Digitalis purpurea, 121

Dilly, 127

Dinner bell, monkey, 93

Dioon, 34

Diospyros, 129

Diphylleia cymosa, 129

Dirca palustris, 13

Disporum, 129

Dittany, 22, 23

Dock, 15

Dog apple, 128
Dog fennel, 12

Dogbane, 104, 105

Dogbane family, 103

Dogberry, 127

Dogwood, 129

Dolichos lablab, 64

Doll's-eyes, 44, 45

Dovyalis, 129

Downy myrtle, 73, 132

Downy thornapple, 114

Duchesnea indica, 130

Dumbcane, 40)

Duranta, 121

Duranta repens, 121,130

Dutchman's breeches, 50

Eggfruit, 131

Elacasnus, 130

Elder, 110

gulf, 111

Mexican, 111

poison, 20.21

red-berried. 111

southern, 111

Elderberry, 110, 132

Elephant ears, 42

Elm, 9

Empetrum, 130

English bean, 68

English ivy, 14, 83, 130

Ephedra, 130

Ericaceae. 98

Erigeron canadensis, 13

Ergot, 29, 71

Eriobotrya japonica, 130

Ervatamia coronaria, 106

Erythroxylaceae, 81

Ervthroxylon coca, 81

Eugenia, 130

Euonymus, 74, 130

Eupatorium rugosum, 124, 125

Euphorbia, 13, 17,90

corollata, 90

cyparissias, 90

lathyris, 91

maculata, 17

marginata, 91

milii, 91

pulcherrima, 92

splendens, 91

tirucallii, 92, 93

Euphorbiaceac, 89

European beech, 72

European bittersweet, 119, 120

Everlasting pea, 65

Eyebane, 17

Fabaceae, 62

Fagaceae, 72

Fagus, 72

grandifolia, 72

sylvatica, 72

Fall poison, 124, 125 
False hellebore, 38

False mastic. 133

False poinciana, 63

False sago palm, 34, 129

False solomon's seal, 133

Fan palm, 134

Fava bean, 68

Feijoa sellowiana, 130

Fern, 34

Fern palm, 34

Feverwort, 133

Ficus, 13, 130

Fiddle, monkey, 92, 93

Fiddlehead. 34

Fiddlewood. Florida, 129

Fig. 13, 130

Finger cherry, 73, 132

Firecracker plant, 80

Firethorn, 132

Fishtail palm. 128 tufted, 13

Flacourtia indica, 130

Flag, 14

Flame vine, Mexican, 15

Flax, 131

Fleabane, daisy, 13

Florida arrowroot, 34, 134

Florida fiddlewood, 129

Flower, cardinal, 122

carrion, 133

crown, 109

kahili. 14

pasque, 46

sky, 121

trumpet. 117

wind, 46

Flowering quince, 129

Flowering spurge, 90

Fool's parsley, poison, 86

Forestiera, 130

Fortunella, 130

Four-o'clock, 56

Four-o'clock family, 56

Foxglove, 121

Fragaria, 130

Frangipani, 14

Fraxinella, 23

French mulberry. 128

Fringe tree, 129

Fumariaceae, 50

Fumitory family, 50

Fungi, 9. 29

Gas plant, 22, 23

Gaultheria, 130

Gaylussacia, 130

Geiger tree, 129

Gelsemium, 14, 102, 103 rankinii, 102

sempervirens, 14, 102, 103

Gentian, horse, 133

Ginger, wild, 13

Ginkgo, 14, 130
Ginkgo biloba, 14, 130

Ginseng, 131

Ginseng family, 83

Gleditsia triacanthos, 65

Gloriosa superba, 36, 37

Glory lily, 36, 37

Glottidium, 63

Golden chain, 65

Golden dewdrop, 121

Golden seal, 46

Goldenrod, rayless, 126

Gooseberry, 132

Gooseberry, hill. 73 otaheite. 132

Gopher apple, 129

Gourd, bitter. 88

Gourd family, 88

Grape, 133

sea, 129

shore. 129

Grape family, 75

Grapefruit. 129

Grass, 9

Green arrow. 131

Green cestrum, 113

Greenbriar. 133

Grevillea banksii, 14

Ground cherry, 116, 132

Ground hemlock, 34, 133

Ground oak, 129

Guaiscum officinale. 83

Guarsteen, 130

Guava, 132 pineapple, 130

Gulf elder, 111

Gum, black, 131 sour, 131

Gymnocladus dioica, 64

Hackberry, 128

Haplopappus heterophyllus, 126

Harrisia, 130

Hashish, 70, 7l

Haw, 133

Hawthorn, 129

Heart, bleeding, 13, 50, 51

Hearts-a-bustin: 74

Heath family. 98

Hedera helix, 14,83, 130

Hedge. 100

Hedysarum mackenzii, 65

Hellebore, 15, 38 false. 38

Helleborus niger, 46

Hemlock, 88

ground, 34,133

poison, 13,86

spotted water, 84

water, 84

Hemp, 70, 71

Hemp. Indian, 104, 105

Hemp family, 70

Henbane, 114 
Henbane, black, 114

Hercules club, 12, 83, 127

Hesperocnide, 14, 22

Heteromeles arbutifolia, 130

Hickory, 9

Hill gooseberry, 73

Hip, rose, 132

Hippeastrum, 39

Hippocastanaceae, 79

Hippomane mancinclla, 14, 17. 92, 130

Hobblebush, 133

Hogplum, 133, 134

Holly, 74, 130

Oregon, 131

Holly family, 74

Honey locust, 64

Honeysuckle, 131

Honeysuckle fámily, 110

Horse apple, 14

Horse bean, 68

Horse gentian, 133

Horse nettle, 117,119

Horsechestnut, 79

Horseradish, 88

Horsesugar, 133

Horseweed, 13

Huckleberry, 130

Hunter's robe, 14

Hura crepilans, 93

Husk tomato, 132

Hyacinth, 38

Hyacinth bean, 64

Hyacinthus orientalis, 38

Hydrangea, 59

mountain, 59

oak-leaf, 59

snowy, 59

Hydrangea, 59

arborescens, 59

macrophylla, 59

quercifolia, 59

radiata, 59

Hydrastis canadensis, 46

Hylocereus undatus, 130

Hyoscyamus niger, 114

Hypericum perforatum, 14

Ilex, 74, 130

vomitoria, 74

Indian cucumber, 131

Indian hemp, 104, 105

Indian jujube, 134

Indian poke, 38

Indian strawberry, 130

Indian tobacco, 14, 122, 124

Indian tree spurge, 92, 93

Inkberry, 50,52

Iris, 14

Irish potato, 120

Ivy, 83

English, 14, 83, 130

mountain, 98, 99

poison, 15, 19, 133
Ivy bush, 98, 99

Jack-in-the-pulpit, 12, 4I, 128

Jack-o'-lantern mushroom, 31, 32

Jackfruit, 128

Jakfruit, 128

Jamestown weed, 112,113

Japan plum, 130

Jasmine, Crape, 106. See also Jessamine

Jatropha, 94, 130

curcas, 94, 95

gossypifolia, 94

integerrima, 94

multifida, 94

stimulosa, 16

Java plum, 130

Jequirity pea, 62

Jerusalem cherry, 116,120

Jessamine, 113, 129. See also Jasmine

Carolina, 102, 103

day-blooming, 113

night-blooming, 113

willow-leaved, 113

yellow, 14, 102, 103

Jetbead, 60

Jetberry bush, 60

Jimmy weed, 126

Jimsonweed, 13, /12, 113

Jonquil, 39

Jujube, 134

Indian, 134

Juneberry, 132

Jungle plum, 133

Juniper, 9, 14, 130

Juniperus, 130

virginiana, 14

Kahili flower, 14

Kale, 88

Kalmia, 98, 99

angustifolia, 98

latifolia, 98, 99

polifolia, 98

Karwinskia humboldtiana, 75, 130

Kei-apple, 129

Kentucky coffee tree, 64

Ketembilla, 129

Key lime, 129

Kinnikinik, 127

Knotweed, 14

Kumquat, 130

Lablab, 64

Laburnum anagyroides, 65

Lactarius, 31

Ladies, naked, 35

Lady's slipper orchid, 13

Lambkill. 98

Lanalana, 128

Langsir, 132 
Lantana, 122, 123, 130

Lantana camara, 122, 123

Lantern. Chinese, 116

Laportea canadensis, 14, 17

Larkspur, 13, 46

Lathyrus, 65

Laurel, 100, 101

California, 133

cherry, 60

mountain, 98,99

sheep. 98

spurge, 72

swamp, 98

Leaf, satin, 129

umbrella, 129

Leatherwood, 13

Lecythidaceae, 73

Lecythis family, 73

Leguminosae, 62

Lemon, 129

Leonurus cardiaca, 14

Leopard's-bane, 124

Lepiota, Morgan's, 32, 33

Lepiota, 32 molybdites, 33

Lignum vitae. 83

Ligustrum, 100

Ligustrum, 130 vulgare, 100

Liliaceae, 35

Lily, blackberry, 128 climbing, 36, 37 glory, 36, 37

Lily family, 35

Lily-of-the-valley, 36 wild, 131

Lily turf, 131

Lime. 13, 129

key, 129

Spanish, 131

Lindera benzoin, 130

Linum, 131

Liriope, 131

Litchi, 131

Litchi sinensis, 131

Liverberry, 133

Lobelia, 14, 122

Lobelia family, 122

Lobelia inflata, 14, 124

Lobeliaceae, 122

Locust, black. 66, 67 honey, 64

Locust berry, 128

Loganberry, 132

Logania family, 102

Loganiaceae, 102

Lonicera, 131

Lophophora williamsii, 56, 57

Loquat, 130 Queensland. 73

Loranthaceae, 76

Love bean, 62

Lucky bean, 62
Lucky nut, 108

Lacuma nervosa, 131

Lychee, 131

Lycium, 131

Lycopersicon esculentum, 115

LSD, 57,71

Maclura pomifera, 14

Macrozamia, 34

Mahogany family, 77

Mahonia, 131

Maianthemum canadense, 131

Maidenhair tree, 14, 130

Malabar tree, 92, 93

Malpighia glabra, 131

Malus, 60, 131

Mamey, 131

Mammea americana, 131

Mammee apple. 131

Mamoncillo, 131

Manchineel, 14, 17, 92, 130

Mandarin, 133

yellow, 129

Mandrake, 14, 47, 132

Mangifera indica, 14, 131

Mango, 14, 131

Manihot esculensa, 94

Manioc, 94

Manzanita, 127

Maple, 9

Marigold, marsh. 46

Marihuana, 70, 7l

Marijuana, 58, 70, 71

Marlberry, 127

Marsh marigold, 46

Marvel-of-Peru, 56

Mastic, false, 133

Mast-wood, 128

Matrimony vine, 131

Mayapple, 14, 47, 132

Maypop, 13!

Meadow saffron, 35

Medeola virginiana, 131

Melalenca leucadendra, 14

Melia azedarach, 77, 78, 131

Meliaceae, 77

Melicocea bijuga, 131

Melonette, 131

Melothria pendula, 131

Menispermaceae, 43

Menispermum canadense, 43,131

Mescal, 56, 57

Mescal bean, 68

Mescal button, 56, 57

Metel, 114

Metopium toxiferum, 14, 18, 131

Mexican elder, 111

Mexican flame vine, 15

Mexican pricklepoppy, 48

Mezereum family, 72

Microcycus, 34

Milk bush, 92.93

Milk purslane, 17 
Milkweed, 109

Milkweed family, 109

Milky-cap mushroom, 31

Mirabilis jalapa, 56

Mistletoe, 27, 76, 77, 132

Mistletoe family, 76

Mitchella repens, 131

Mole plant, 91

Momordica charantia, 88, 131

Monkey dinner bell, 93

Monkey fiddle, 92, 93

Monkey pot, 73

Monkshood, 44

Monstera, 42, 131

Monstera deliciosa, 131

Moonseed, 43, 129, 131

Moonseed family, 43

Moraceae, 70

Morel, 30

Morgan’s lepiota, 32, 33

Morning glory, 71

Morus, 131

alba, 70

rubra, 14, 70

Motherwort, 14

Mountain ash, 133

Montain hydrangea, 59

Mountain ivy, 98, 99

Mountain laurel, 98, 99

Mountain snuff, 124

Mountain tobacco, 124

Moxieplum, 130

Mulberry, 131

French, 128

red, 14,70

white. 70

Mulberry family, 70

Musaceae, 35

Mushroom. 29

Mustard, 88

Mustard family, 88

Myristica fragrans, 42

Myristicaceae, 42

Myrtaceae, 73

Myrtle, 131

downy, 73,132

Myrtle family, 73

Mvrus communis, 131

Nagoonberry, 132

Naked ladies, 35

Nandina, 131

Nandina domestica, 131

Nannyberry, 133

Nurcissus, 39

Natal plum, 128

Nerium, 14, 107, 108 indicum, 108 oleander, 14, 107

Nettle, 17

bull, 16

horse, 117,119

spurge, 13,16 stinging, 15, 22, 23

western stinging, 14

wood, 14, 17

Nicandra physalodes, 116, 131

Nicotiana, 116

glauca, 116

tabacum, 116

trigomophylla, 116

Night-blooming cereus, 130

Night-blooming jessamine, 113

Nightshade, 117, 133

black. 117,118

climbing. $1 / 9,120$

deadly, $111,119,120$

yellow, 109

Nut, areca, 42

Barbados, 94, 95

betel, 42,128

buffalo, 132

candle, 90,127

cashew, 12

lucky, 108

physic, 94, 95

purge, 94, 95, 130

tung, 89, 127

Nutmeg, 42

Nutmeg family, 42

Nycraginaceae, 56

Nysisa, 131

Oak. 9. 72

ground, 129

poison, 15, 19, 133

western poison, 18

Oak family, 72

Oak leaf hydrangea, 59

Ochrosia elliptica, 108, 131

Ochrosia plum, 108, 131

Ohio buckeye, 79

Old man's beard, 129

Oleaceac, 100

Oleander, 14, 107

yellow, 108

Oleaster, 130

Olive, Russian. 130 wild, 130

Olive family, 100

Olive plum, 129

Opium poppy, 49

Opuntia, 131

Opuntia cactus, 131

Orange, 129

Osage, 14

Seville, 129

sour, 129

trifoliate, 129,132

Orchid, lady's slipper, 13

Oregon holly, 131

Ornithogalum umbellatum, 38

Osage orange, 14

Osmanthus, 131

Otaheite gooseberry, 132

Oyster plant, 15 
Painted buckeye, 80

Palm, betel nut, 42 cabbage, 132 coconut. 129 false sago, 34, 129 fan. 134 fern. 34 palmetto. 132 royal, 132 silver, 129 thatch, 129 tufted fishtail, 13 Washington. 134

Palm family, 42

Palmae, 42

Palmetto, saw, 133

Palmetto palm, 132

Panax quinguefolia, 131

Paparer sommiferum, 49

Papaveraceac, 48

Papaya, 13, 128

Paradise tree, 133

Parilla, yellow, 43

Parsley, poison fool's, 86

Parsnip, wild, 22, 23

Purthenocissus, 75, 76, 131 quinquefolia, 75, 76, 131 vilacea, 75

Partridgeberry, 131

Pasqueflower, 46

Passiflora, 131

Passion fruit. 131

Pastinaca sativa, 22

Pawpaw, 13, 128

Pea, everlasting, 65 jequirity, 62 rosary, 62 singletary, 65 sweet, 65 wild sweet, 65

Pea family, 62

Peach, 60, 132

Pear, 132 balsam, 88, 131 prickly, 131

Peltandra virginica, 131

Pencil tree, 13,92,93

Pepper, bird, 13 Brazilian, 15 chili, 128

Peraphvllum ramosissimum, 131

Peregrina, 94

Persea. 132 americana, 132 borbonia, 132

Persimmon, 129

Peru, apple-of-, 116,131 marvel-of- 56

Peyote, 56,57

Phaceliu, 14

Pheasant's eye, 46
Philodendron, 42

Phoradendron, 27, 76, 77, 132 flavescens, 27, 76, 77 serotimum, 27, 76, 77, 132

Photinia, 132

Phvllanthus acidus, 132

Physalis, 116, 132 peruliana, 117

Physic nut, 94, 95

Phviolacca, 132 americana, 50,53 rigida, 50, 53, 54

Phytolaccaceae, 50

Pickerelweed. 132

Pigeon plum, 129

Pigeonberry, 50, 52, 121,130

Pikeweed, 132

Pimpernel, scarlet, 12

Pine, prince's. 13

Pineapple-guava, 130

Pink allamanda, 109

Pink family. 54

Pipsissewa, 13

Pitaya, 130

Pitch apple, 129

Pithecellobium, 14

Pithecellobium dulce, 14

Plum, 60, 132

coco, 129

darling, 132

hog. 133, 134

Japan. 130

Java, 130

jungle, 133

moxie, 130

natal, 128

ochrosia, 108, 131

olive, 129

pigeon, 129

saffron, 128

tallowwood. 134

Plumbago. 14

Plumbage capensis, 14

Plumeria, 14

Podophyllum pelianum, 14, 47, 132

Poinciana, 66 false. 63

Poinciana gilliesii, 66

Poinsettia, 13, 17, 92

Poison. fall. 124, 125

Poison ash, 20, 21

Poison efder, 20, 21

Poison fool's parsley, 86

Poison hemlock. 13,86

Poison ivy, 15, 19, 133

Poison oak, 15, 19, 133

Poison oak, western, 18

Poison sumac, $15,20,21,133$

Poison wood, 14, 18, 131

Poisonberry. 113

Poke, 50, 52

Indian, 38 
Pokeberry, 50, 52, 132

Pokeweed, 50, 52

Pokeweed family, 50)

Polvgonaceac, 58

Polygonatum, 132

Polvgonum, 14

Polvescias, 14

Pomegranate, 132

Pometia pinnata, 132

Pencirus trifoliata. 132

Pond apple, 127

Pongam, 66

Pongamia pimnata, 66

Pontederia cordata, 132

Poplar, 9

Popolo, yellow-fruited, 120

Poppy, common, 49

Mexican prickle, 48

opium. 49

prickly, 48

rock, 49

Poppy family, 48

Pot, 70, 71

Potato. 120

Irish, 120

white. 120

Potato family, 111

Prayer bean, 62

Precatory bean. 62

Pricklepoppy. Mexican, 48

Prickly apple, 130

Prickly pear, 131

Prickly poppy, 48

Primrose, 14

Primula, 14

Prince's pine, 13

Privet. 100,130

Prumus, 132 scrotina, 60.61

Psidium guajouva, 132

Puffball, 30

Punica granatum, 132

Punk tree, 14

Purge nut, 94.95, 130

Purple allamanda, 109

Purple queen, 15

Purple sesban. 63

Purslane. milk, 17

Pyracamtha, 132

Prrularia pubera, 132

Pyrus, 132

Queen, purple, 15

Queen palm. 128

Queensland loquat. 73

Quercus, 72

Quince. 129

flowering, 129

Radish. 88

horse, 88

Ragweed. 10, 12

Raisin. wild, 133

Ramontchi. 130
Ranumerulacese, 44

Ranumculus, 14, 47

Raspherry, 132

Rattlebox, 63

Rayless goldenrod, 126

Red bay, 132

Red buckeye, 80

Red cedar, 14

Red mulberry, 14,70)

Red sage, 122, 123

Red sapote, 128

Red-berried elder, III

Revnosia seprentrionalis, 132

Rhucoma, 132

Rhammaceare, 75

Rhammus, 75,132 cathartica, 75 purshiana, 75

Rhaphidophora aurea, 14

Rheum rhaponticum, 58

Rhododendron, 100,10 I

Rhododendron, 100, 10! macrophyllam, 100 maximum, 100, 101

Rhodomyrtus, 132 macrocarpa, 73 tomentosa, 73

Rhodotvpos tetrapetala, 60

Rhoes ipathacea, 15

Rhubarb, 58

Rhüs, 132 diversiloba, 18 radicans, 19, 20 loxicodendron, 19 vernix, 20,21

Ribes, 132

Ricinus communis, 96

Rivina humilis, 132

Robinia psendoacacia, 66, 67

Robe, hunter's, 14

Rock poppy, 49

Root, arnica, 124

Rosa, 132

Rosaceae. 60

Rosary pea. 62

Rose, 132

Rose bay, 100, 10I

Rose. Christmas, 46

Rose family, 60

Rose hip. 132

Rouge plant, 132

Royal palm, 132

Rovstonea, 132

Rubber vine, 13, 109

Rubus, 132

Rumex, 15

Russian olive, 130

Russula. 32

Rutabaga, 88

Sabal palmetto, 132

Saffron, meadow. 35

Saffron plum, 128

Sage, red, 122, 123 
Sago palm, false, 34, 129

St. John's wort, 14

Salal, 130

Salmonberry, 132

Sambucus, 110, 132

canadensis, 110, 132

mexicana, 111

pubens, 111

simpsonii, 111

Sandbox tree, 93

Sanguinaria canadensis, 15,49

Sapindaceae, 78

Sapindus, 133

Sapodilla, 127

Sapote, black, 129 red, 128

Sarsaparilla, 127

Sassafras, 133

Sassafras albidum, 133

Sassy jack, 91

Satin leaf, 129

Saw palmetto, 133

Saxifragaceac, 59

Saxifrage family, 59

Scarlet cordia, 129

Scarlet pimpernel, 12

Schinus terebinthifolius, 15, 133

Scootberry, 133

Scrophulariaceae, 121

Scurvyberry, 133

Sea grape, 129

Seal, golden, 46

Senecio confusus, 15

Serenoa repens, 133

Serviceberry, 127

Sesban, 63

purple, 63

Seshania, 63

Setcreasea purpurea, 15

Seven-year apple. 128

Sevenbark, 59

Seville orange, 129

Shadberry, 127

Sheep laurel, 98

Shepherdia, 133

Shoofly plant, 116

Shore grape, 129

Sideroxylon foetidissimum, 133

Silver leaf, 59

Silver palm, 129

Silverberry, 130

Simarouba glarca, 133

Singletary pea, 65

Skyflower, 121

Smartweed, 14

Smilacina racemosa, 133

Smilax, 133

Snakeberry, 44, 45

Snakeroot, black, 39

white, 124,125

Snapdragon family, 121

Snowberry, 133

Snowdrop, 38

Snow-on-the-mountain, 91
Snowy hydrangea, 59

Snuff, mountain, 124

Soapberry, 133

Soapberry family, 78

Sodom, apple of, 120

Soil algae, 9

Solanaceae, 111

Solandra, 117

Solanum, 117, 133

americanum, 117,118

carolinense, 117,119

dulcamara, 119, 120

nigrum, 117

pseudocapsicum, 120

sodomeum, 120

ulberosum, 120

Solomon's seal, 132 false, 133

Sophora secundiflora, 68

Sorbus, 133

Sorrel, 15

Sour gum, 131

Sour orange, 129

Soursop, 127

Southern elder, 111

Spanish lime, 131

Sparkleberry. 133

Spicebush, 130

Spikenard, 127

Spindle tree. 74

Spondias, 133

Spotted cowbane, 84

Spotted spurge, 17

Spotted water hemlock, 84

Spring adonis, 46

Spurge, 13, 90)

caper, 91

cypress, 90

flowering, 90

Indian tree. 92,93

spotted, 17

stinging, 13, 16

Spurge family, 89

Spurge laurel. 72

Spurge nettle, 13, 16

Squashberry. 133

Squaw apple. 131

Squirrel corn, 50

Staff-tree family, 74

Staggerweed, 46

Stalk. twisted, 133

Star apple, 129

Star-of-Bethlehem, 38

Stinging nettle, 15, 22, 23 western, 14

Stinging spurge, 13,16

Stinking cedar, 133

Stinkweed, 1/2, 113

Stock, 88

Stopper, white. 130

Strawberry, 130

barren, 134

Indian, 130

Strawberry blite, 129 
Strawberry bush, 74, 130

Strawberry tomato, 116

Strelitzia, 35

Streplepus, 133

Strongbark, 128

Bahama. 128

Strychnine, 102, 133

Strychnes nux-10)mica, 102, 133

Sugarberry, 128

Sumac, 132

Sumac, coral, 18 poison, $15,20,21,133$ swamp, 20, 21

Supplejack, 128

Surinam cherry, 130

Swamp laurel, 98

Swamp sumac, 20,21

Sweet pea, 65

Sweetbay, 132

Sweetleaf, 133

Sweetsop, 127

Sycamore, 9

Symphoricarpos, 133

symplocos tinctoria, 133

Tallowwood plum, 134

Tapioca, 94

Taxaccae, 34

Tuxus, 34, 133

baccata, 34

brevifolia, 35

canadensis, 34

cuspidata, 34

floridana, 35

Teaberry, 130

Thatch palm, 129

Theretia peruviana, 108, 133

Thimbleberry, 132

Thimbleweed, 46

Thorn, box-. 131

Thornapple, 48, 112, 113

Thornapple, downy, 114

Thunderwood, 20,21

Thymelaeaceae, 72

Tiger apple, 108, 133

Tinker's weed, 133

Toadflax, bastard, 129

Toadstool, 29

Tobacco, 116

Indian, 14, 122, 124

mountain, 124

tree, 116

wild, 116

Tomato, 115

husk, 132

strawberry, 116

wild, 117,119

Torreya, 133

Toxicodendron, 15, 133

diversilobum, 18

quercifolitsm, 19

radicans, 19

vernix, 20,2I

Tread-softly, 16
Tree cactus, 128

Tree spurge, Indian, 92, 93

Tree tobacco, 116

Tree-of-heaven, 12

Trifoliate orange, 129, 132

Trifolium hybridım, 15

Trillium, 133

Triosteum, 133

Trumpet, angel's, 114, 1/5 devil's, 114

Trumpet creeper, 13, 15

Trumpet flower, 117

Tufted fishtail palm, 13

Tung nut, 89, 127

Tung oil tree, 89

Tupelo, 13 I

Turf, lily, 131

Turkey corn, 50

Turnip, 88

Twisted stalk, 133

Umbelliferae, 84

Umbellalaria californica, 133

Umbrella leaf. 129

Urechites, 109

Urtica dioica, 15, 22, 23

Vaccinium, 133

Veratrum, 15 californicum, 38 parififorum, 38 viride, 38

Verbenaceae, 121

Vervain family, 121

Vetchlings. 65

Vi apple. 133

Viburnum, 133

Vicia faha. 68

Virginia creeper, 75, 76, 131

Virgin's bower, 13, 46

Viscaceae. 76

Vitaceare, 75

Vitis, 133

Wahoo, 74

Wake-robin. 133

Waldsteinica fragarioides, 134

Walkingstick, devil's, 83

Wartweed, 17

Washington palm, 134

Washingtonia filifera, 134

Water hemlock. 84

Water hemlock, spotted. 84

Waterberry, 131

Waxberry, 133

Weed, burrow, 126

Jamestown, 1/2, 113

jimmy, 126

jimson, 112,113

pickerel, 132

pike, 132

poke. 50

tinker's, 133

Western poison oak, 18 
Western stinging nettle. 14

White cohosh. 44. 45

White mulberry, 70

White potato, 120

White snakeroot, 124, 125

White stopper, 130

Wi tree. 133

Wicky, 98

Wikstroemia, 134

Wild allamanda, 109

Wild balsam apple, 88

Wild calla, 128

Wild carrot, 13

Wild cherry, 60,61

Wild coffee, 133

Wild cucumber. 133

Wild ginger, 13

Wild lily-of-the-valley, 131

Wild olive, 130

Wild parsnip, 22, 23

Wild raisin, 133

Wild sweet pea, 65

Wild tobacco, 116

Wild tomato, 117, 119

Willow-leafed jessamine, 113

Windflower, 46

Windsor bean. 68

Wineberry, 132

Wintergreen, 130

Wisteria, 69

sinensis, 69

Wood nettle, 14, 17

Wolfsbane, 44

Ximenia americana, 134

Yellow allamanda, 12, 103,104

Yellow buckeye, 79

Yellow jessamine, 14, 102, 103

Yellow mandarin. 129

Yellow nightshade, 109

Yellow oleander. 108

Yellow parilla, 43

Yellow-fruited popolo, 120

Yew, 34, 133

Yew family, 34

Ylang-ylang, 128

Zamia, 34, 134

Zigadenus, 39

Zizyphus, 134 jujuba, 134

mauritiana, 134

Zygophyllaceae, 83 



W.

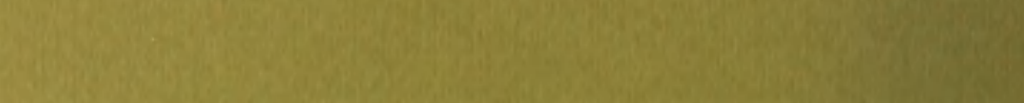

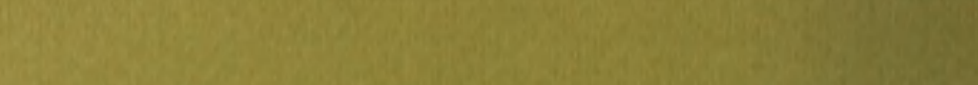
4hing

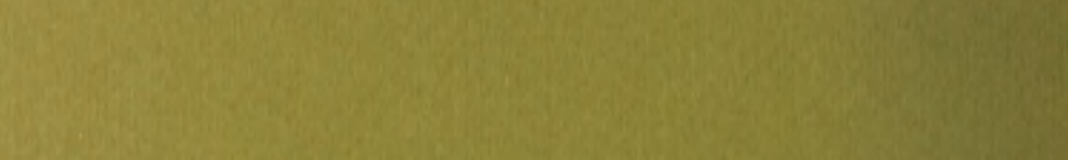

How

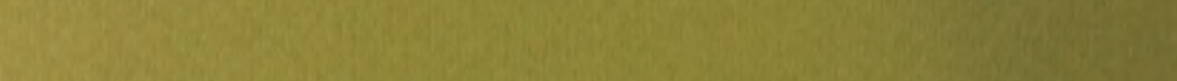

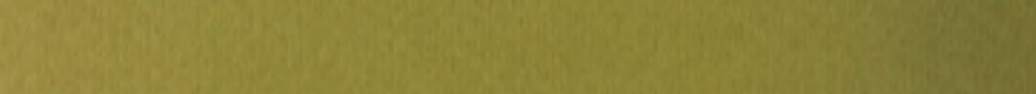

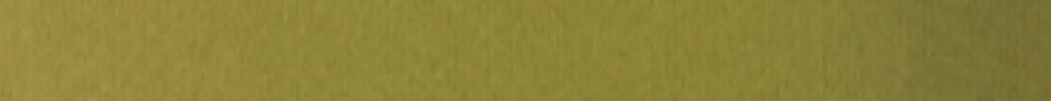

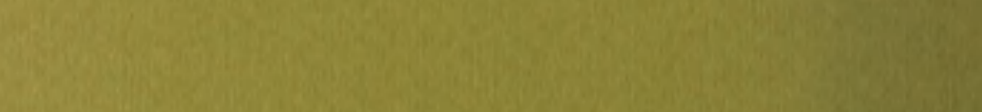

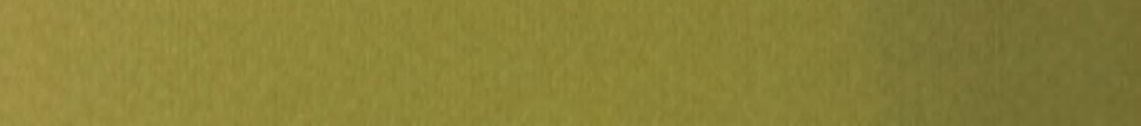

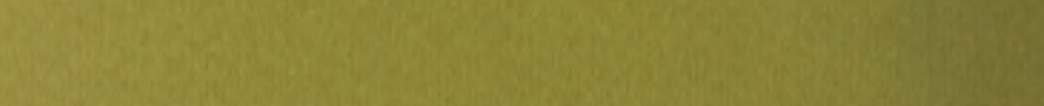

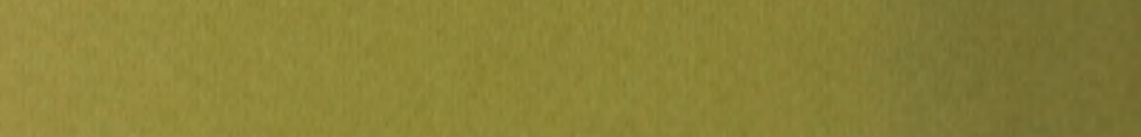

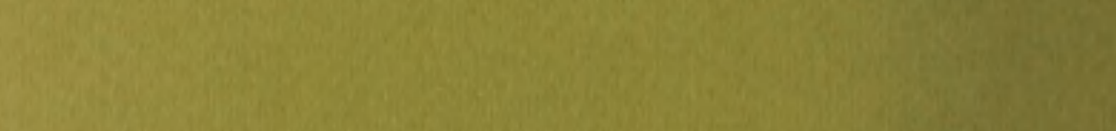

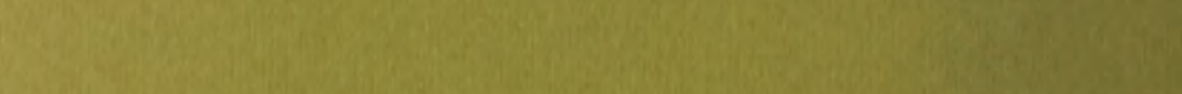

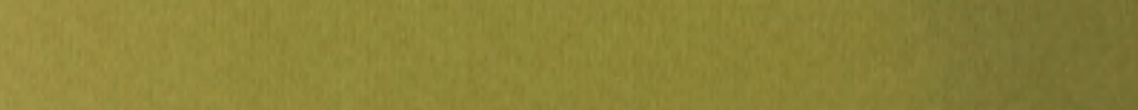

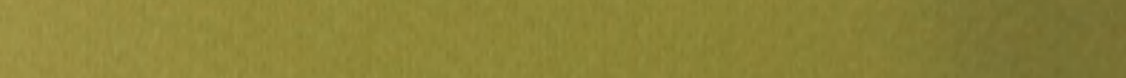
10 6he

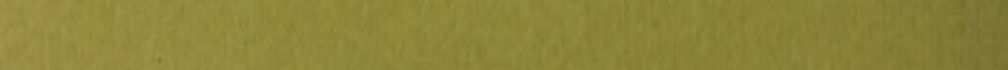
(4)

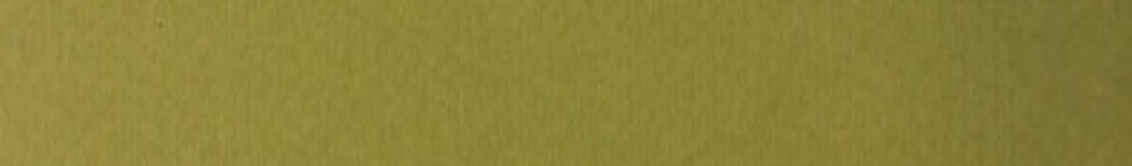

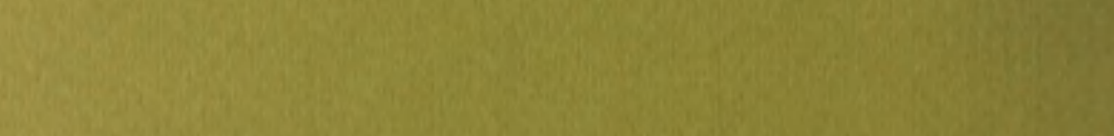

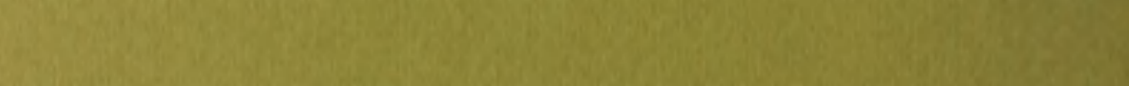
What (2) W.

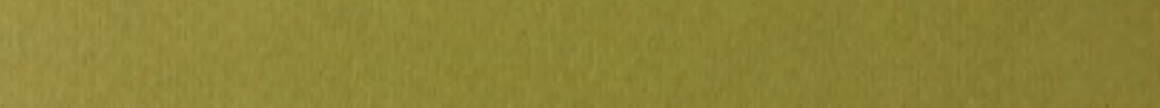

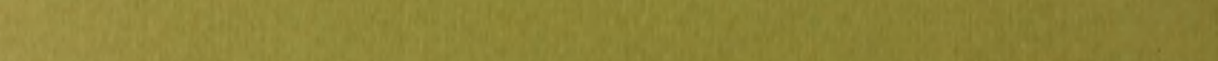

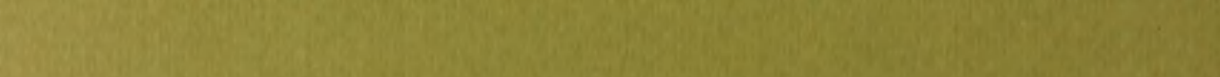

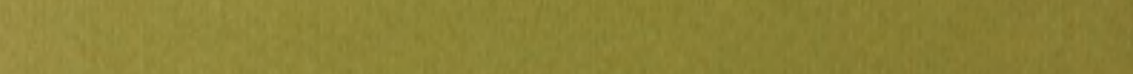
What

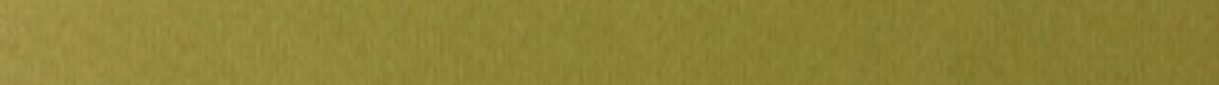


late. A unique list of over 200 berries (both native and cultivated) provides a rapid means of finding out if a particular berry is poisonous; information is also given on how "safe" berries should be eaten. There are even some instructions on what to do if your pet is poisoned by a plant.

Human Poisoning from Native and Cultivated Plants is the first concise treatment of this important subject. It is designed for parents, teachers, camp counselors, scout leaders, nurses, health officers, physicians, and botanists-in short, for everyone who must know quickly whether or not a particular plant is poisonous. All plants, except bacteria, known or suspected to have poisoned humans in the continental United States, Canada, Alaska, and Hawaii-over 300 varieties of plants-are examined. Most of the discussions include the scientific and common names and a description of the plant, information on the geographical area and habitat, discussion of the effects and symptoms of the poisoning, and notes to the physician on treatment; many are illustrated with line drawings or photographs. An illustrated glossary explains the descriptive terms used in the book. And there is a bibliography of the otherwise bewilderingly diverse source materials that can lead the reader to more detailed and technical information.

James W. Hardin is Professor of Botany and Forestry and Curator of the Herbarium at North Carolina State University. $\mathrm{He}$ also serves as the President and Chairman of the Board of the Highlands Biological Station. Mr. Hardin has written numerous articles for scientific journals as well as several bulletins on poisonous plants for the North Carolina Agricultural Experiment Station.

Jay M. Arena is Professor of Pediatrics at Duke Hospital and Director of the Duke University Medical Center Poison Control Center. $\mathrm{He}$ is President of the American Association of Poison Control Centers and District IV Chairman of the American Academy of Pediatricians. Dr. Arena is author of Poisoning: Chemistry, Symptoms, and Treatment, and has published many articles. 


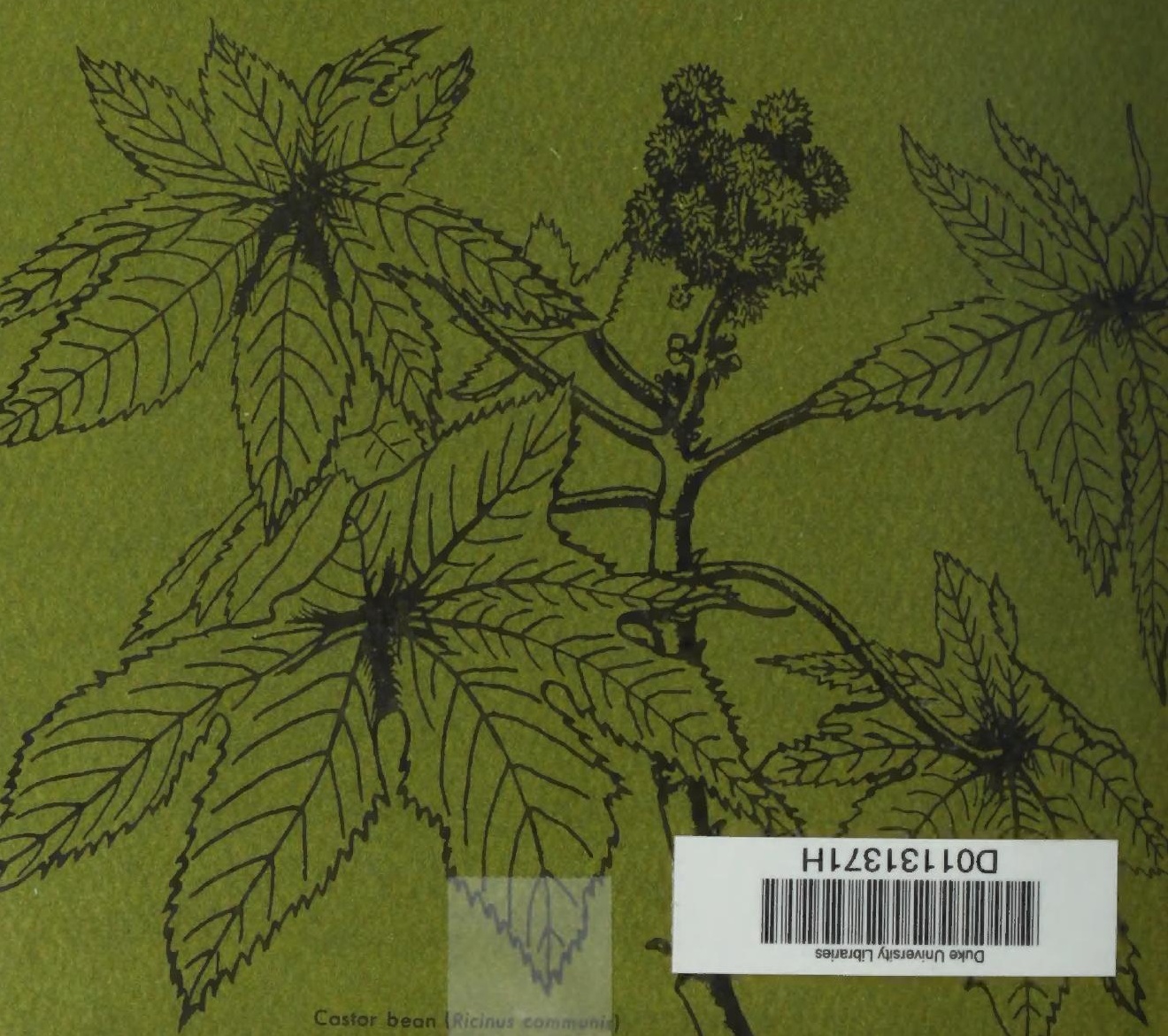

